This report was prepared as an account of Government sponsored work. Neither the United States, nor the Commission, nor any person octing on behalf of the Commission:

A. Mokes ony worronty or representotion, expressed or implied, with respect to the aecurecy, completeness, or usefulness of the information contained in this report, or thet the use of any information, apparatus, method, or process disclosed in this report moy not infinge privotely owned rights; or

B. Assumes any liobilities with respect to the use of or for damoges fesulting tram the use of any information, apparatus, method, or process disclosed in this report.

As used in the above, "pers on acting on behalf of the Commission" includes any employe or contractor of the Cammission, or employe of such contractor, to the extent that such employee of confroctor of the Commission, or emplayee of such contractor prepares, disseminates, or provides access to, any informotion pursuant to his employment or contract with the Cammission, or his employment with such contractor. 
ORNL-TM- 252

\author{
CHEMICAL TECHNOLOGY DIVISION \\ AND \\ HEALTH PHYSICS DIVISION
}

\title{
WASTE TREATMENT AND DISPOSAL PROGRESS REPORT \\ FOR FEBRUARY AND MARCH 1962
}

R. E. Blanco and E. G. Struxness

\section{DATE ISSUED \\ SEP 101962}
OAK RIDGE NATIONAL LABORATORY
Oak Ridge, Tennessee
Operated by
UNION CARBIDE CORPORATION
For the
U. S. ATOMIC ENERGY COMMISSION


CONTENTS

$\begin{array}{lll}1.0 & \text { INTRODUCTION } & 7\end{array}$

2.0 HIGH-LEVEL WASTE CALCINATION 8

2.1 Engineering-Scale Pot-Calcination Development 8

2.2 Pilot Plant Design 14

2.3 Design of Radioactive Cell Equipment 20

2.4 Laboratory-Scale Fixation 22

3.0 LOW-LEVEL WASTE TREATMENT 30

3.1 Pilot Plant 30

3.2 Process Development 33

4.0 ENGINEERING, ECONOMICS, AND HAZARD EVALUATION 39

4.1 Economics of Solids Disposal in Salt 39

4.2 Shipment of Calcined Solids 42

5.0 DISPOSAL IN DEEP WELI

5.1 Disposal by Hyaraulic Fracturing 45

6.0 DISPOSAL IN NATURAL SALT FORMATIONS 50

6.1 High-Temperature Experiments 50

6.2 Calculation of Thermal Stresses and 56

Plastic Deformations Around Heat-Generating Cylinders Stored in Salt

6.3 Trapped Moisture in Natural Salt Formations 58

6.4 Effect of Salt Extraction and Depth on 58

Stability of Mine Openings

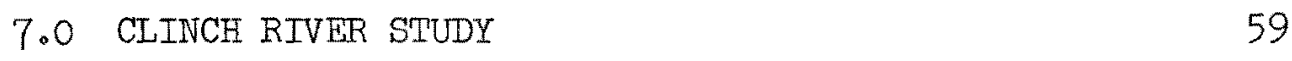

7.1 Flow Routing 59

7.2 Effect of Geology on Quality of Water 63 of Clinch River Tributaries 
8.0 FUNDAMENTAL STIDIES OF MINERALS 63

8.1 Behavior of Cesium in Vermiculite Systems 63

9.0 WHITE OAK CREEK BASIN STUDY 69

9.1 Sources of White Oak Creek Contamination 69

9.2 Hydrology of White Oak Creek Basin 73

10.0 REFERENCES 
High-Level Waste Calcination. Process flowsheets and an equipment layout were completed for the Idaho Chemical Processing Plant Pot Calcination Pilot Plant. A mercury trap for removal of mercury compounds from the calciner off-gas was designed and fabricated, and several welded closures for sealing pots were leak-tested at the Georgia Nuclear Laboratory; the leak rate was less than 0.2 std ce of helium per year.

A mathematical study initiated to predict the control pattern for a pot during calcination indicated that, at a certain critical cake thickness, the wall temperature of the calciner must be programmed to ensure that all portions of the cake achieve, yet not exceed, approximately $1650^{\circ} \mathrm{F}$ 。

Decreasing the pressure from 750 to $570 \mathrm{~mm} \mathrm{Hg}$ had little effect on the relative volatilities of ruthenium from $6 \mathrm{M} \mathrm{HNO}_{3}$. Addition of $0.1 \mathrm{M} \mathrm{H} \mathrm{PO}_{3}$ to nitrate solutions of ruthenium chloride and ruthenium nitrosohydroxide with and without salts occurring in waste solutions decreased the ruthenium distillation by factors varying from 2920 for $6 \mathrm{M} \mathrm{NNO}_{3}$ containing ruthenium nitrosohydroxide to 38.8 for simulated Darex waste containing ruthenium chloride.

The thermal conductivities of a lead phusphate glass were 1.05 and $1.60 \mathrm{Btu} \mathrm{hr}^{-1} \mathrm{ft}^{-1} \mathrm{~F}^{\mathrm{cl}}$ ats 300 and $1050^{\circ} \mathrm{F}$, respectively. The production of this glass on a semiengineering scale was accompanied by volatilization of $12.5 \%$ of the original ruthenium and physical entrainment of $<0.02 \%$ of the promethium as determined from counting Ru-106 and Pm-147 tracers.

Simulated Darex waste soiution was incorporated into glassy and microcrystalline phosphate and borophosphate solids with softening points of 850 to $900^{\circ} \mathrm{C}$ and densities of 2.73 to $3.75 \mathrm{~g} / \mathrm{cc}_{\text {, }}$ and containing 13.4 to 32.3 wt $\%$ waste oxldes, representing volume reductions of 2.9 to 6.6 .

Low-Level Waste Treatment. The results of four demonstration runs in the Pilot Plant, with ORNL process waste water as feed, were essentially the same as previous ones: Sr-90 d.f. 2000 12,000: Cs-137 d.f. 77 - 3000. Flant effluent solutions contained $<3 \%$ of current $\mathrm{MFC}_{\mathrm{W}}$ values for all isotopes at the $2000 \mathrm{mbed}$ volume level $(56,000 \mathrm{gal})$. A resin column isotope breakthrough run (HR-6) indicated a Sr-90 release to plant effluent after 2916 bed volumes.

The pretreatment protion of the scavenging-ion exchange process was improved by the addition of calcium carbonate to the flash mixer contents, either as $25 \mathrm{ppm}$ of $\mathrm{Ca}(\mathrm{OH})_{2}$ which precipitated $\mathrm{CaCO}_{3}$, or as recirculated sludge from the clarifier. The limecaustic-copperas treatmeni was shown to be temperature dependent, 
with minimum residual hardness at $26^{\circ} \mathrm{C}$. Results of tap water treatment in a laboratory-scale sludge blanket clarifier containing an inner cone indicated that a size reduction of 10-20 is possible over present equipment.

Engineering, Economics, and Hazards Evaluation. A preliminary conceptual design and cost estimate for a solids disposal facility in salt indicated costs of from $6 \times 10^{-3}$ to $30 \times 10^{-3} \mathrm{mill} / \mathrm{kwh}$. Sixty to $85 \%$ of the total costs were attributable to mining, indicating that the best possible estimates of this item will be required for the more detailed final study.

Heat transfer calculations of shipping containers for potcalcined wastes of various ages showed that as many as thirty-six 6-in.-dia pots of calcined acidic Purex waste can be shippea in a single finned carrier after 2.4 years' decay without mechanical cooling enroute. Four 24-in.-dia pots of acidic Purex waste can be shipped, per carrier, after 11 years' decay.

Disposal in Deep Wells. Slurries were made with simulated ORNL intermediate-activity wastes and portiand cement which met the pumping time requirements. The salts in the waste solution did not cause unexpected reactions that are undesirable for pumping operations and did not prohibitively alter the setting properties of Portland cement slurries.

Disposal in Natural Salt Formations. Four plastic-flow measurement stations have been installed in the Carey Salt Company mine at Hutchinson, Kansas. Each station consists of from seven to nine gages installed in such a way as to measure both floor and ceiling movement and movement of the columns. The stations are installed in areas of varying age, from recent to early in development of the mine. Two additional gages remain to be installed. An array of 20 holes for the study of effect of high temperatures on rock salt in situ was successfully drilled without use of a liquid drilling medium. Samples of dry shale from the holes contained 10 to $12 \%$ water.

Clinch River Study. During periods free from storm runoff in the summer months, power waves in the Clinch River study reach are classified as uniformly progressive flow. For this type of flow the storage of water in the study reach is conditioned equally by the inflow and outflow rates. By expressing the storage as a weighted function of these rates, the variations in flow due to power releases in the Clinch River above Centers Ferry, near Kingston, Tenn., may be determined from flow records obtained at the upstream gaging station on the Clinch River near Scarboro, Tenn.

Stable chemical analyses of water samples taken during base flow measurements in september 1961 show a marked difference in the quality of water between streams draining coal-bearing 
$-6-$

clastic rocks of the Cumberland escarpment and streams draining predominantly carbonate rocks of the ridge and valley province in which Oak Ridge National Laboratory is located. Streams draining the Cumberland escarpment contain a greater proportion of sulfate, sodium, and chloride and have higher $\mathrm{pH}^{\prime} \mathrm{s}$ than do streams draining the ridge and valley province.

Fundamental Studies of Minerals. The cesium exchange properties of vermiculite were improved by collapsing the vermiculite lattice with ammonium ions or with one of the heavy alkali metal cations. Pretreatment of the vermiculite with potassium increased the number of exchange sites at the edges of collapsed basal spacings, where cesium can be incorporated into the lattice by "edge fixation." Tinis increased the cesium $\mathrm{K}_{d}$ in $0.5 \mathrm{M} \mathrm{NaNO} 3$ by a factor of 2.7 . Addition of $\mathrm{NH}_{4}^{+}$, $\mathrm{Cs}^{+}, \mathrm{Rb}^{+}$, or $\mathrm{K}^{+}$to the influent resulted in

"interlayer fixation" of cesium as a result of collapse of the lattice to physically entrap the cesium sorbed at the basal surface exchange sites. In this case the cesium $\mathrm{K}_{\mathrm{d}}$ was increased by a factor of about 4.4 .

White Oak Creek Basin Study. For the period May to October 1961, the Process Waste Water Treatment Plant accounted for about $92 \%$ of the $\mathrm{Sr}-89$ and $\mathrm{Sr}-90$, 91\% of the rare earths (exclusive of $\mathrm{Y}-90$ ), $72 \%$ of the $\mathrm{Cs}-137,76 \%$ of the Co-60, and $84 \%$ of the Ru-106 discharged to White Oak Creek in Bethel Valley. Of the smaller contributors, the amount of activity detected in the sanitary sewage effluent. was the most significant. The mean concentration of Sr-90 in the effluent for the sampling period was $1.7 \times 10^{-6} \mu \mathrm{c} / \mathrm{cc}$ or about $40 \%$ of MPC for continuous occupational exposure, 40-hr week. Analyses of samples taken at temporary monitoring stations along White Oak Creek and its tributaries indicate a relation between the suspended solid load in the stream and cesium transport. 


\section{$-7-$}

\subsection{INIRODUCTION}

This report is the sixth of a series* of bimonthly reports on progress in the ORNL development program, the objective of which is to develop and demonstrate on a pilot plant scale integrated processes for treatment and ultimate disposal of radioactive wastes resulting from reactor operations and reactor fuel processing in the forthcoming nuclear power industry. The wastes of concern include those of high, intermediate, and low levels of radioactivity in liquid, solid, or gaseous states.

Principal current emphasis is on high-and low-activity liquid wastes. Under the integrated plan, low-activity wastes, consisting of very dilute salt solutions, such as cooling water and canal water, would be treated by scavenging and ion exchange processes to remove radioactive constituents and the water discharged to the environment. The retained waste solids or slurries would be combined with the high-level wastes. Alternatively, the retained solids or the untreated waste could be discharged to the environment in deep geologic formations. The high-activity wastes would be stored at their sites of origin for economic periods to allow for radioactive decay and artificial cooling.

Two methods are being investigated for permanent disposal of high-activity wastes. One approach is conversion of the liquids to solids by high-temperature "pot" calcination or fixation in the final storage container (pot) itself and storage in a permanently dry environment such as a salt mine. This is undoubtedly the safest method since complete control of radioactivity can be ensured within present technology during treatment, shipping, and storage. Another approach is disposal of the liquid directly into sealed or vented salt cavities. Research and development work is planned to determine the relative feasibility, safety, and economics of these methods, although the major effort will be placed on conversion to solids and final storage as solids.

Tank storage or high-temperature calcination of intermediatelevel wastes may be unattractive because of their large volumes. Consequently, other disposal methods will be studied. One method, e.g., addition of solidifying agents prior to direct disposal into impermeable shale by hydrofracturing, is under investigation at present. Particular attention is given to the engineering design and construction of an experimental fracturing plant to dispose of ORNL intermediate-level wastes by this method if proved feasible.

Environmental research on the Clinch River, motivated by the need for safe and realistic permissible limits of waste releases, is included in this program. The objective is to obtain a detailed characterization of fission product distribution, transport, and accumulation in the physical, chemical, and biological segments of this environment.

*Previous reports in this series are ORNL-CF-61-7-3, ORNL-TM-15, ORNL-TM-49, ORNL-TM-133, and ORNL-TM-169. 


\subsection{HIGH-LEVEL WASTE CALCINATION}

The pot calcination process for converting high-activity-level wastes to solids is being studied on both a laboratory and engineering scale to provide design information for construction of a pilot plant. Development work has been with synthetic Purex, Darex, and TBP-25 wastes containing millicurie amounts of ruthenium but has not been demonstrated on actual high-activity-level wastes. A general flowsheet was shown previously (I). In phase I operations, the pilot plant will demonstrate calcination with the addition of additives limited to those necessary to repress volatilization of components such as sulfate or ruthenium. In phase II, the pilot plant will demonstrate fixation where additives will transform the waste to glasses.

\subsection{Engineering-Scale Pot-Calcination Development (J. C. Suddath, C. W. Hancher)}

Recent data are being compiled and evaluated. A review of 21 engineering scale tests, made to develop the evaporation and calcination part of the pot-calcination flowsheet, is presented here. The tests were made with a small continuous evaporator and a large batch evaporator.

A close-coupled continuous evaporator and an 8-in.-dia by 90-in.-high calciner operated satisfactorily with simulated Purex, Darex, and TBP-25 waste (Table 2.1). The average feed rate for TBP waste was 25-30 liters/hr and for Purex, 20-25 liters/hr. The calcination time was an additional 8-10 hr, and the change-out time 8-10 hr. Purex waste from processing of 1.75-2.0 tons of urarium could be calcined in I day on a 2-day cycle. The average feed rate for Darex waste was 10-20 liters/hr. Average decontamination factors across the evaporator (FIg. 2.1) were about 103: 1200 from sulfate, 700 from iron, and 1000 from ruthenium. The evaporator was operated with little or no de-entraining medium, but, in a welldesigned evaporator with adequate de-entraining space and medium, larger d.f.'s would be expected. Decontamination across the calciner is less important since its off-gas is recycled to the evaporator. Approximately $1 \%$ of the sulfate, $7 \%$ of the metal ions, and $8 \%$ of the ruthenium are expected to be returned to the evaporator (Fig. 2.1).

The system (Fig. 2.2) consists of a natural circulation evaporator equipped with a $22-\mathrm{ft}^{2}$ heat exchanger, which uses 100-psi steam as the heating medium. A bottom drawoff from the evaporator connects to a pump loop, which flows past the calciner not and returns to the evaporator. To decrease changes of plugging and to maintain a constant feed to the calciner, a 10-gpm flow is maintained in this loop. The pipe for the small sidestream of liquid drawn off through a control valve into the calciner pot is kept as short as possible, $2 \mathrm{ft}$, and the control valve is placed as near the operating loop as possible. A water purge bled into the feed stream downstream of the control valve at 1 liter/hr decreases the frequency of plugging. 
Table 2.1 Results of Waste Calciner Tests

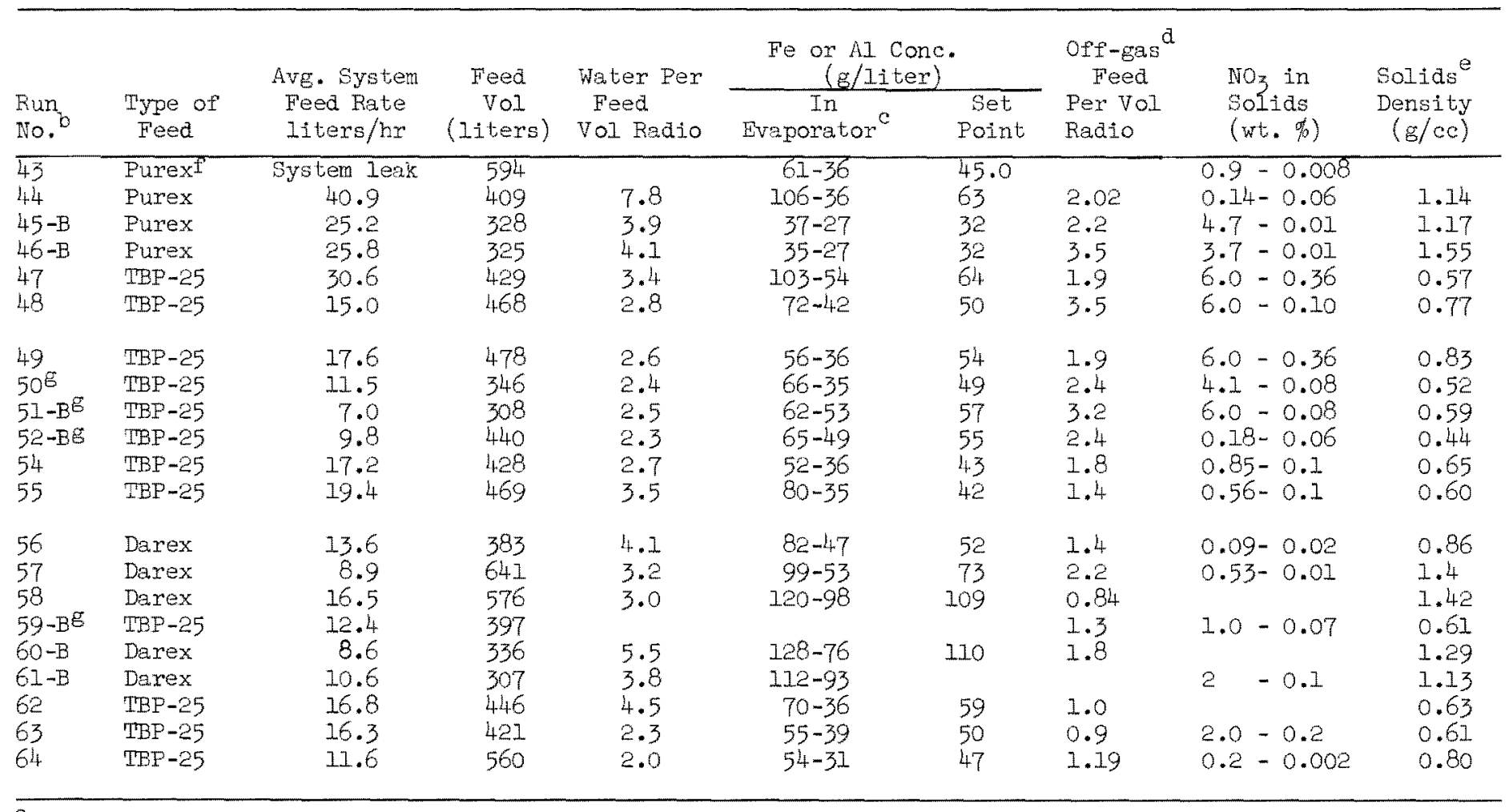

\begin{tabular}{llllllllll}
\hline \multicolumn{10}{c}{ The Concentrations $(\mathrm{M})$ are: } \\
\hline Waste & $\mathrm{H}^{+}$ & $\mathrm{NO}_{3}$ & $\mathrm{SO}_{4}^{\overline{4}}$ & $\mathrm{Cl}^{-}$ & $\mathrm{Fe}^{3+}$ & $\mathrm{Al}^{3+}$ & $\mathrm{Ni}^{2+}$ & $\mathrm{Cr}^{2+}$ & $\mathrm{Na}^{+}$ \\
Conc.Purex & 5.6 & 6.1 & 1.0 & & 0.5 & 0.1 & 0.01 & 0.01 & 0.6 \\
Darex & 3.0 & 5.0 & & 0.1 & 0.68 & 0.12 & & 0.08 & 0.16 \\
TBP-25 & 0.5 & 5.4 & 0.03 & & 0.002 & 1.16 & 0.12 & &
\end{tabular}

b In "B" runs batch evaporation was used; In all others it was continuous.

c Concentration range during calclner feeding in Purex batch evaporations.

d Includes 10-20 $\mathrm{ft} / \mathrm{hr}$ system leakage.

e Bulk density $=$ weight of solid divided by 60 liters.

$f$ No $\mathrm{Ca}\left(\mathrm{NO}_{3}\right)_{2}$ added.

g $1 \mathrm{ml}$ each DEP \& MBP added to feed before processing. 
UNCLASSIFIED

ORNL-LR-DWG $63286 R 2$

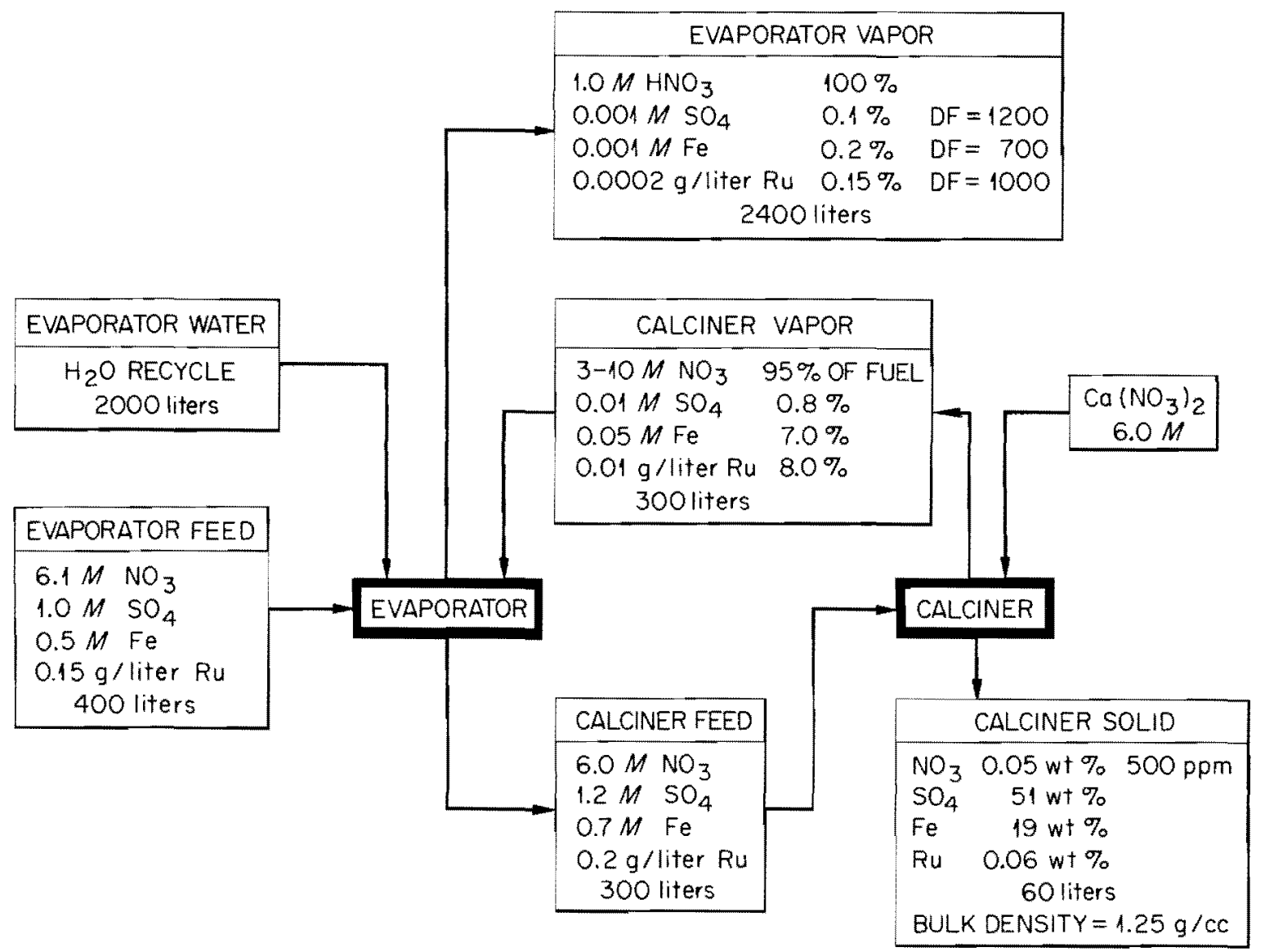

Fig. 2.1. Purex Material Distribution Flowsheet for ContinuousEvaporation System. The numbers represent best averages from a number of tests. 
$-11-$

UNCLASSIFIED

ORNL-LR-DWG $63205 R 2$

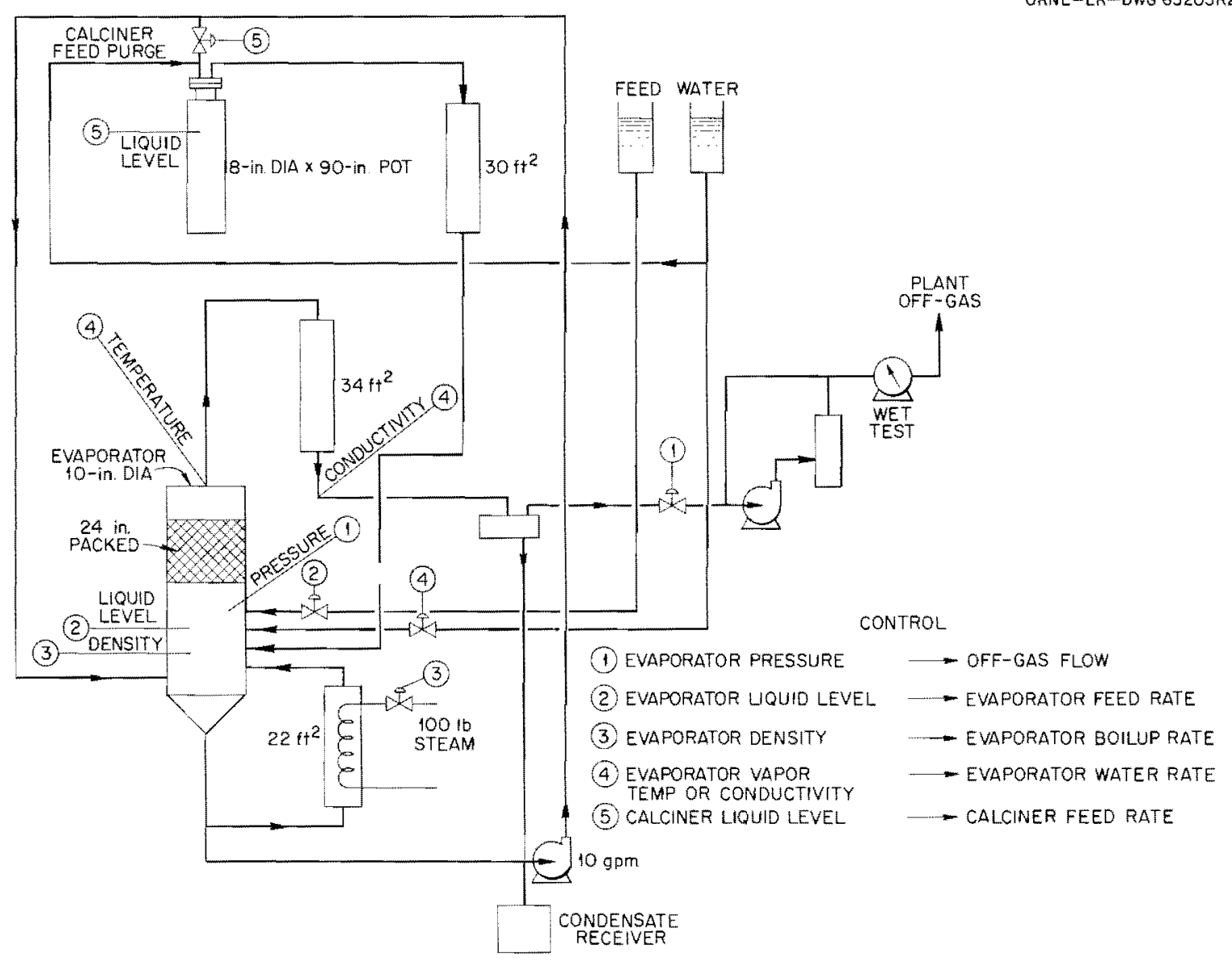

Fig. 2.2. Calciner-Continuous Evaporator Control Flowsheet. 
The calciner vapor is condensed in a 30-ft2 downdraft heat exchanger and returned directly to the evaporator. The liquid is supercooled to recover $85-95 \%$ of the nitric oxides and decrease the gas volume for better decontamination. Recycled water and feed are added to the evaporator through their individual control valves from head tanks. The evaporator vapor passes through a de-entraining section and then to a $34-f t^{2}$ heat exchanger which operates downdraft. The condensable fraction of the vapor goes to a condensate receiver, where it is measured and discharged through a pressure seal. The noncondensable vapor goes to the off-gas system, where it is filtered and the volume is measured in a wet test meter.

The off-gas from a typical 30-hr Purex waste run was $1100 \mathrm{cu} \mathrm{ft}^{3}$, or $36 \mathrm{ft}^{3} / \mathrm{hr}$, of which $32 \mathrm{cu} \mathrm{ft/hr}$ was instrument purge and inleakage gas. The system operated under 1 psi vacuum. The $4 \mathrm{ft}^{3} / \mathrm{hr}$ of noncondensable gas averaged $3 \mathrm{ft}^{3}$ of oxygen per hour. Excess oxygen is always present in the off-gas from decomposition of nitrate to $\mathrm{NO}_{2}$ and $\mathrm{O}_{2}(\underline{2})$ and at times was as high as 34 vol \%. This small amount of of $\hat{\mathrm{f}}$ gas can be easily decontaminated and discharged to the environment.

The evaporator had a 4-6 liters/min boilup rate and operated normally with 25-30 liters holdup. The calciner pot had a nominal 1 liter/min water boilup rate at the full $54 \mathrm{kw}$ heat input. As the solids are radially deposited on the walls of the vessel, the heat input to the pot is decreased. The external wall of the calciner is held at a maximum of $900^{\circ} \mathrm{C}$ by the furnace, which is divided into six sections, each about $13 \mathrm{in.} \mathrm{high.} \mathrm{The} \mathrm{furnace}$ temperature could go to $1050^{\circ} \mathrm{C}$ before there was danger of bumout.

The variables that must be controlled in the process are:

1. Acidity in the evaporator, which is kept below $6 \mathrm{M}$, to decrease ruthenium volatility, by recycling water or weak nitric acid from the distillation column to the evaporator. The amount recycled is controlled by the nitric acid and metal ion concentrations in the evaporator, which determine the vapor temperature (Fig. 2.3), and the preferred operating range is between 0.5 and $0.7 \mathrm{M}$ iron and between 4 and $6 \mathrm{M} \mathrm{H} \mathrm{H}^{+}$for Purex waste. Increasing the rate of water addition increases the vapor volume and therefore the required capacities of the evaporator and distillation column.

2. Metal ion concentration in the evaporator, which is kept maximum, limited by solution stability, by controling the liquid density by varying the amount of steam used to vaporize the liquid.

3. Liquid level in the evaporator, which is controlled by the amount of evaporator feed added to the system. 


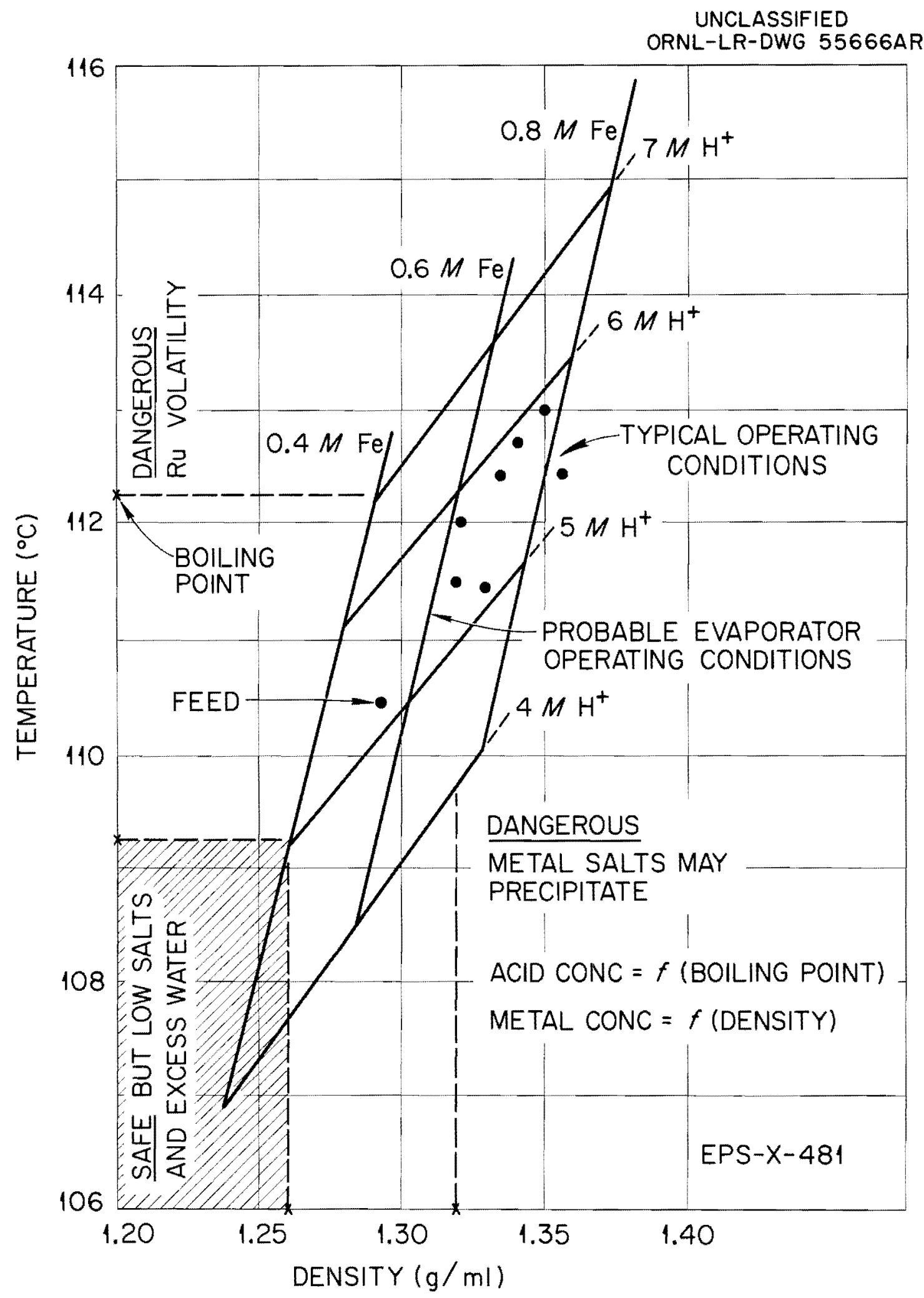

Fig. 2.3. Boiling Point at Atmospheric Pressure vs Density of Purex Waste as Function of Acid and Metal Salt. 
$-14-$

4. Pressure in the evaporator, which is kept below atmospheric to prevent outleakage of radioactive off-gas, by regulating the off-gas vacuum pump.

5. Calciner pot liquid level, which was controlled by a differential temperature device consisting of a rod down the center of the calciner pot extending 9-12 in. below the liquid level (Fig.2.4). When the liquid level is above the lower thermocouple but has not reached the rod, the rod is heated by radiation from the walls of the pot. When liquid reaches the end of the rod, the rod begins to transfer its heat to the liquid. The temperature at the thermocouple point is a function of the height of liquid on the thermocouple rod, and, by maintaining a temperature difference of $100^{\circ} \mathrm{C}$ between the two thermocouples, it is possible to maintain a liquid level 4 in. lower than the thermocouple in the rod. A differential pressure bubbler satisfactorily indicated the calciner liquid level until the latter part of the test when the bubbler tubes became plugged giving a high-liquid-level signal which cut off the feed.

The control results for tests $R-42$ to $R-64$ were analyzed on the basis of the following control limits which were found suitable:

Calciner liquid level

Evaporator density

Evaporator Iiquid level

Evaporator temperature or conductivity

Evaporator pressure

$$
\begin{aligned}
& \frac{\%}{95-20 \approx 57 \text { to } 63 \text { liters }} \\
& \pm 50.05 \mathrm{~g} / \mathrm{cc} \\
& \pm 20 \approx \pm 4 \text { Iiters } \\
& \pm 5 \approx \pm 0.05 \underline{\mathrm{M}}\left(\mathrm{HNO}_{3}\right) \\
& \pm 2 \approx \pm 0.1 \mathrm{psig}
\end{aligned}
$$

In some of the first tests the control was very poor (Tables 2.22.6) because of equipment failure, poor signal pickup, range control (proportional band and reset, Table 2.7 , and misjudged operating variables. However, during later tests control was much improved.

2.2 Pilot Plant Design (J.M.Holmes, E. J. Frederick, J. O. Blomeke)

Flowsheets. Furex waste calcination material balance flowsheets were completed for use in the design of the Pot Calcination Pilot Plant at the Idaho Chemical Processing Plant. A revised process flowsheet was issued which incorporates agreed-upon changes in the feed evaporator size, calciner, and fractionator condenser arrangement, calciner pressure relief system, calciner feed system, and the method for determining the composition of the evaporator overhead (a conductivity cell will be installed as an alternative use of the vapor temperature as a measure of its acidity). Detailed design of the equipment based on this flowsheet is proceeding at the ICPP. 
UNCLASSIFIED

ORNL-LR-DWG 63192R

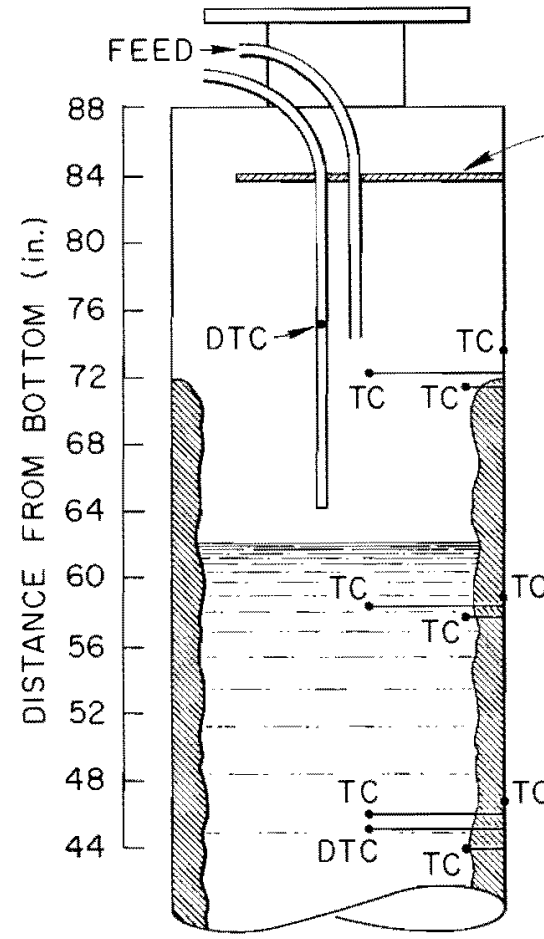

A BAFFLE

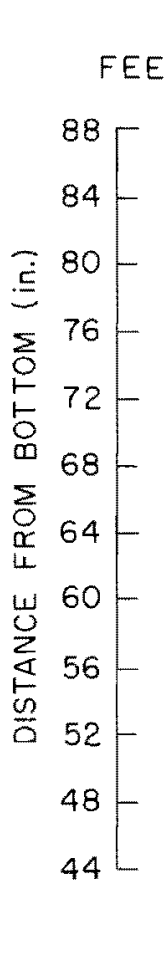

DCT $\triangle T=220^{\circ} \mathrm{C}-120^{\circ} \mathrm{C}=100^{\circ} \mathrm{C}$

DCT $\triangle T=600^{\circ} \mathrm{C}-120^{\circ} \mathrm{C}=480^{\circ} \mathrm{C}$ TOP BOTTOM CONTROL RANGE $=50-150^{\circ} \mathrm{C}$ FOR $0-100 \%$ CONTROL OUTPUT

Fig. 2.4. Dual Themocouple Temperature Control system. 
Table 2.2 Calciner Liquid Level Control

\begin{tabular}{|c|c|c|c|c|c|c|c|}
\hline \multirow[b]{2}{*}{$\begin{array}{l}\text { Run } \\
\text { No. }\end{array}$} & \multicolumn{2}{|c|}{ Over Limits } & \multicolumn{2}{|c|}{ Under Limits } & \multirow{2}{*}{$\begin{array}{l}\text { Outside } \\
\text { Limits } \\
\text { (\% of time) }\end{array}$} & \multirow{2}{*}{$\begin{array}{l}\text { Total } \\
\text { Control } \\
\text { Time (hr) }\end{array}$} & \multirow{2}{*}{$\begin{array}{c}\text { Control } \\
\text { Limits } \\
(\% \text { of range) }\end{array}$} \\
\hline & $\begin{array}{l}\text { \% of } \\
\text { time }\end{array}$ & $\begin{array}{l}\text { No. of } \\
\text { tines }\end{array}$ & $\begin{array}{l}\text { \% of } \\
\text { time }\end{array}$ & $\begin{array}{l}\text { No. of } \\
\text { times }\end{array}$ & & & \\
\hline$R-42$ & 3.7 & 6 & 25.6 & 6 & 29 & & $95-20$ \\
\hline$R-43$ & 14.2 & 3 & 12.7 & 3 & 26.9 & 7.5 & $95-20$ \\
\hline$R-44$ & 41.5 & 9 & 29.1 & 9 & 70.6 & 15 & $95-20$ \\
\hline$R-45 *$ & 5.9 & 6 & 63.5 & 12 & 69.4 & 11 & $95-20$ \\
\hline$R-46 *$ & 57.1 & 2 & 32.6 & 3 & 89.7 & 15 & $95-20$ \\
\hline$R-47$ & 54.1 & 3 & 17.7 & 6 & 22.8 & 14 & $95-20$ \\
\hline$R-48$ & 11.4 & 4 & 15.7 & 10 & 27.1 & 16 & $95-20$ \\
\hline$R-49$ & 4.0 & e & 41.0 & 5 & 45.0 & 12 & $95-20$ \\
\hline$R-50$ & 5.6 & 27 & 40.8 & 37 & 46.4 & 21 & $95-20$ \\
\hline $\mathrm{R}-51 *$ & 26.7 & 61 & 53.8 & 70 & 80.5 & 39 & $95-20$ \\
\hline$R-52^{*}$ & 8.1 & 8 & 18.0 & 10 & 26.1 & 39 & $95-20$ \\
\hline$R-54$ & 17.8 & 15 & 61.8 & 25 & 79.6 & 30 & $95-20$ \\
\hline$R-55$ & 26.4 & 22 & 46.4 & 59 & 72.8 & 28 & $95-20$ \\
\hline$R-56$ & 23.5 & 21 & 56.4 & 19 & 79.9 & 37 & $95-20$ \\
\hline$R-57$ & 0 & 0 & 8.8 & 12 & 8.8 & 72 & $95-20$ \\
\hline$R-58$ & 3.4 & 8 & 52.0 & 10 & 55.4 & 30 & $95-20$ \\
\hline$R-59 *$ & 0 & 0 & 57.3 & 6 & 57.3 & 27 & $95-20$ \\
\hline $\mathrm{R}-60^{*}$ & 0.6 & 4 & 28.4 & 22 & 29.0 & 39 & $100-20$ \\
\hline $\mathrm{R}-6 I^{*}$ & 2.3 & 2 & 14.1 & 6 & 16.4 & 22 & 95.20 \\
\hline$R-62$ & 8.6 & 3 & 10.6 & 7 & 19.2 & 23 & $95-20$ \\
\hline$R-63$ & 0 & 0 & 16.7 & 4 & 16.7 & 23 & $95-20$ \\
\hline$R-64$ & 13.5 & 1 & 2.8 & 3 & 16.3 & 32 & $95-20$ \\
\hline Avg. & 12.7 & 9.4 & 32.1 & 15.6 & 44.8 & 30.0 & - \\
\hline
\end{tabular}

*Batch; other continuous.

Table 2.3 Evaporator Density Control

\begin{tabular}{|c|c|c|c|c|c|c|c|}
\hline \multirow{3}{*}{$\begin{array}{l}\text { Run } \\
\text { No. }\end{array}$} & \multicolumn{2}{|c|}{ Over Limits } & \multicolumn{2}{|c|}{ Under Limits } & \multirow{3}{*}{$\begin{array}{l}\text { Outside } \\
\text { Iimits } \\
\text { ( } \% \text { time) }\end{array}$} & \multirow{3}{*}{$\begin{array}{l}\text { Total } \\
\text { Control } \\
\text { Time }\end{array}$} & \multirow{3}{*}{$\begin{array}{l}\text { Control } \\
\text { Limits } \\
\text { (\% of set point }\end{array}$} \\
\hline & of I & No. of & of & No. of & & & \\
\hline & time & times & time & times & & & \\
\hline$R-42$ & 96.4 & 4 & 3.3 & 4 & 99.7 & 17 & \pm 5 \\
\hline$R-43$ & 0 & 0 & 85.4 & 3 & 85.4 & 8 & \pm 5 \\
\hline$R-44$ & 16.4 & 1 & 66.4 & 3 & 82.8 & 6 & \pm 5 \\
\hline$R-45^{*}$ & 40.8 & 5 & 0 & 0 & 40.8 & 2 & \pm 5 \\
\hline$R-46^{*}$ & Manual & & & & & & \\
\hline$R-47$ & 8.7 & 2 & 63.7 & 6 & 72.4 & 16 & \pm 5 \\
\hline$k-48$ & 51.2 & 7 & 10.5 & 5 & 61.7 & 16 & \pm 5 \\
\hline$R-49$ & 11.1 & 6 & 27.8 & 8 & 38.9 & 27 & \pm 2 \\
\hline$R-50$ & 21.4 & 7 & 17.9 & 7 & 39.3 & 23 & \pm 5 \\
\hline$R-5 I^{*}$ & 0.13 & $i$ & 8.5 & 5 & 8.6 & 39 & \pm 5 \\
\hline $\mathrm{R}-5 \mathrm{Z}^{*}$ & 0 & 0 & 69.7 & 2 & 69.7 & 7 & \pm 5 \\
\hline$R-54$ & 79.2 & 2 & 17.5 & 2 & 96.7 & 38 & \pm 2 \\
\hline$R-55$ & 18.6 & 3 & 25.0 & 6 & 43.6 & 25 & \pm 2 \\
\hline$R-56$ & 43.0 & 20 & 12.6 & 9 & 55.6 & 31 & \pm 2 \\
\hline$R-57$ & 0.42 & 3 & 3.0 & 5 & 3.4 & 72 & \pm 5 \\
\hline $\mathrm{R}-58$ & 0 & 0 & 4.2 & 5 & 4.2 & 30 & \pm 5 \\
\hline $\mathrm{R}-5 \%^{*}$ & Menual & & & & & & \\
\hline$R-60^{*}$ & 14.1 & 1 & 3.2 & 2 & $17 \cdot 3$ & 39 & \pm 5 \\
\hline$R-61^{*}$ & Manual & & & & & & \\
\hline$R-62$ & 0.04 & 1 & 29.0 & 4 & 29.1 & 8 & \pm 5 \\
\hline$R-63$ & 3.2 & 3 & 13.3 & 7 & 16.5 & 28 & \pm 5 \\
\hline$R-64$ & 0 & 0 & 1.5 & 3 & 1.5 & 46 & \pm 5 \\
\hline Avg. & 21.3 & 3.5 & 24.3 & 4.5 & 45.6 & 24.8 & - \\
\hline
\end{tabular}

*Batch; other continuous. 
Table 2.4 Evaporator Liquid Level Control

\begin{tabular}{|c|c|c|c|c|c|c|c|}
\hline \multirow{3}{*}{$\begin{array}{l}\text { Run } \\
\text { No. }\end{array}$} & \multicolumn{2}{|c|}{ Over Limits } & \multicolumn{2}{|c|}{ Under Iimits } & \multirow{3}{*}{$\begin{array}{l}\text { outside } \\
\text { Limit } \\
\text { of time }\end{array}$} & \multirow{3}{*}{$\begin{array}{l}\text { Total } \\
\text { Control } \\
\text { Time }\end{array}$} & \multirow{3}{*}{$\begin{array}{l}\text { Control Limits } \\
+ \text { and - } \\
\text { of of set point }\end{array}$} \\
\hline & $\%$ of & No. of & $\%$ of & No. of & & & \\
\hline & time & times & time & times & & & \\
\hline $\mathrm{R}-42$ & 4.1 & 4 & 21.9 & 5 & 26.0 & 22 & \pm 20 \\
\hline$R-4.3$ & 0 & 0 & 1.2 & 3 & 1.2 & 15 & \pm 20 \\
\hline $\mathrm{B}-4 \overrightarrow{4}$ & 14.7 & 10 & 7.1 & 8 & 21.8 & 15 & \pm 20 \\
\hline$R-45^{*}$ & 19.9 & 1 & 0 & 0 & 19.9 & 15 & \pm 20 \\
\hline$R-46 *$ & 0 & 0 & 0.11 & 1 & 0.11 & 15 & \pm 20 \\
\hline$R-47$ & 6.2 & 4 & 0.4 & 1 & 6.6 & 20 & \pm 20 \\
\hline$R-48$ & 11.1 & 3 & 1.8 & 6 & 12.9 & 16 & \pm 20 \\
\hline$E-49$ & 0.4 & 1 & 1.2 & 3 & 1.6 & 27 & \pm 20 \\
\hline$R-50$ & 18.8 & 14 & 9.5 & 12 & 28.4 & 24 & \pm 20 \\
\hline$R-5 I^{*}$ & Manua 1 & & & & & & \\
\hline $\mathrm{R}-52 *$ & Manual & & & & & & \\
\hline$R-54$ & 12.2 & 10 & 2.8 & 4 & 15 & 38 & \pm 20 \\
\hline $\mathrm{F}-55$ & 6.8 & 7 & 2.1 & 2 & 8.9 & 25 & \pm 20 \\
\hline R-56 & 32.8 & 17 & 0 & 0 & 32.8 & 27 & \pm 20 \\
\hline $\mathrm{B}-57$ & 9.7 & 6 & 0 & 0 & 9.7 & 72 & \pm 20 \\
\hline $\mathrm{R}-58$ & 3.7 & 3 & 0.2 & 1 & 3.9 & 39 & \pm 20 \\
\hline$R-59 *$ & Manual & & & & & & \\
\hline $\mathrm{R}-60^{*}$ & ManuaI & & & & & & \\
\hline $\mathrm{R}-6 \mathrm{I}^{*}$ & Manua I & & & & & & \\
\hline $\mathrm{R}-62$ & 8.6 & 3 & 5.6 & 5 & 14.2 & 16 & \pm 20 \\
\hline $\mathrm{k}-63$ & 8.1 & 13 & 0.4 & 1 & 8.5 & 29 & \pm 20 \\
\hline$R-64$ & 5.4 & 5 & 3.6 & 3 & 9.0 & 38 & \pm 20 \\
\hline Avg. & 9.6 & 5.9 & 3.4 & 3.2 & 23 & 26.7 & - \\
\hline
\end{tabular}

*Batch; other continuous.

Table 2.5 Evaporator Temperature or Conductivity

\begin{tabular}{|c|c|c|c|c|c|c|c|}
\hline \multirow{3}{*}{$\begin{array}{l}\text { Fun } \\
\text { No. }\end{array}$} & \multicolumn{2}{|c|}{ Over Limit } & \multicolumn{2}{|c|}{ Under Limits } & \multirow{3}{*}{$\begin{array}{l}\text { Outside } \\
\text { Limit } \\
\% \text { time }\end{array}$} & \multirow{3}{*}{$\begin{array}{l}\text { Total } \\
\text { Control } \\
\text { Time }\end{array}$} & \multirow{3}{*}{$\begin{array}{l}\text { Control Limits } \\
\quad+\text { and - } \\
\text { of set point }\end{array}$} \\
\hline & of of & No. of & of & No. of & & & \\
\hline & time & times & time & times & & & \\
\hline$E-42$ & 2.3 & 4 & 56.3 & 5 & 58.6 & 22 & \pm 5 \\
\hline$R-43$ & 16.5 & 7 & 12.5 & 4 & 29 & 8 & \pm 5 \\
\hline$R-4 \sqrt[4]{4}$ & 3.8 & 7 & 48.7 & 11 & 52.5 & 15 & \pm 5 \\
\hline $\mathrm{R}-\mathrm{l}_{4} 5^{*}$ & 2.4 & 1 & 32.1 & 3 & 34.5 & 15 & \pm 5 \\
\hline$R=i+6 *$ & 0 & 0 & 7.5 & 1 & 7.5 & 15 & \pm 5 \\
\hline $\mathrm{R}-47$ & 23.2 & 5 & 45.7 & 5 & 68.9 & 20 & \pm 5 \\
\hline$R-48$ & 2.8 & 2 & 46.1 & 8 & 4.8 & 16 & \pm 5 \\
\hline$R-49$ & 0 & 0 & 50.0 & 5 & 50.0 & 12 & \pm 5 \\
\hline$R-50$ & 0 & 0 & 68.0 & 8 & 68.0 & 23 & \pm 5 \\
\hline $\mathrm{R}-5 \mathrm{I}^{*}$ & 0 & 0 & 1.3 & $I$ & 1.3 & 18.42 & \pm 5 \\
\hline $\mathrm{R}-52^{*}$ & 10.8 & 3 & 47.2 & 11 & 58.0 & 38 & \pm 5 \\
\hline$R-54$ & 0.3 & 2 & 99.3 & 5 & 99.6 & 38 & \pm 5 \\
\hline $\mathrm{R}-55$ & 6.7 & 7 & 34.0 & 14 & 40.7 & 25 & \pm 5 \\
\hline$R-56$ & 1.9 & 3 & 27.4 & 9 & 29.3 & 31 & \pm 5 \\
\hline$R-57$ & 0.2 & 5 & 7.1 & 7 & 7.3 & 72 & \pm 4 \\
\hline$R-58$ & 1.0 & 1 & 22.1 & 13 & 22.2 & 30 & \pm 4 \\
\hline $\mathrm{R}-59 *$ & Manual & & & & & & \\
\hline $\begin{array}{l}\mathrm{F}-60^{*} \\
\mathrm{R}-67^{*}\end{array}$ & 3.4 & 1 & 23.7 & 3 & 27.1 & 39 & \pm 4 \\
\hline R -62 & 3.8 & 6 & 16.2 & 8 & 20.0 & 25 & \pm 5 \\
\hline $\mathrm{P}-63^{* *}$ & 16.4 & 29 & 28.2 & 24 & 44.6 & 29 & \pm 15 \\
\hline $\mathrm{R}-64 * *$ & 18.0 & 12 & 16.0 & 8 & 34.0 & 45 & \pm 15 \\
\hline Avg. & 56.8 & 4.8 & 34.5 & 7.6 & 37.9 & 26.8 & - \\
\hline
\end{tabular}

**onductivity 
$-18-$

Table 2.6 Evaporator Vapor Pressure Control

\begin{tabular}{|c|c|c|c|c|c|c|c|}
\hline $\begin{array}{l}\text { Run } \\
\mathrm{NO} . \\
\end{array}$ & $\begin{array}{l}\text { Over } \\
\text { \%o of } \\
\text { time }\end{array}$ & $\begin{array}{c}\text { Limits } \\
\text { No. of } \\
\text { times }\end{array}$ & $\begin{array}{l}\text { Under } \\
\text { of of } \\
\text { time }\end{array}$ & $\begin{array}{l}\text { Limits } \\
\text { Wo. of } \\
\text { times }\end{array}$ & $\begin{array}{l}\text { Outside } \\
\text { Limit } \\
\text { of Time }\end{array}$ & $\begin{array}{l}\text { Total } \\
\text { Control } \\
\text { Tame }\end{array}$ & $\begin{array}{l}\text { Control Limits } \\
+ \text { and - } \\
\text { o of set point }\end{array}$ \\
\hline$R-42$ & 0.68 & 2 & 0.3 & 3 & 1.0 & 22 & \pm 2 \\
\hline$R-43$ & 15.1 & 6 & $0.1 \overline{4}$ & 1 & 15.2 & 24 & \pm 2 \\
\hline$R-44$ & 2.8 & 16 & 6.4 & 15 & 8.2 & 23 & \pm 2 \\
\hline$R-45^{*}$ & * 14.2 & 6 & 0.06 & 1 & 14.3 & 27 & \pm 2 \\
\hline$R-46 *$ & $* 72.7$ & 8 & 0.56 & 2 & 73.4 & 15 & \pm 2 \\
\hline$R-47$ & $7 \cdot 3$ & 3 & 11.1 & 6 & 18.4 & 20 & \pm 2 \\
\hline$R-48$ & 6.3 & 2 & 46.7 & 6 & 53.0 & 16 & \pm 2 \\
\hline$R-49$ & 0.77 & 2 & 0.77 & 3 & 1.5 & 13 & \pm 2 \\
\hline$R-50$ & 6.3 & 2 & 46.7 & 6 & 53.0 & 16 & \pm 2 \\
\hline $\mathrm{R}-51 *$ & 0.3 & 3 & 0.81 & 3 & 1.1 & 39 & \pm 2 \\
\hline $\mathrm{R}-52^{*}$ & 3.1 & 4 & 0.17 & 2 & 3.3 & 39 & \pm 2 \\
\hline$R-54$ & 9.5 & 8 & 4.2 & 7 & 13.7 & 28 & \pm 2 \\
\hline$R-55$ & 21.4 & 8 & 1.8 & 9 & 23.2 & 28 & \pm 2 \\
\hline$R-56$ & 1.1 & 9 & 1.1 & 9 & 2.2 & 31 & \pm 2 \\
\hline$R-57$ & 0 & 0 & 0 & 0 & 0 & 72 & \pm 2 \\
\hline$R-58$ & 0 & 0 & 0 & 0 & 0 & 30 & \pm 2 \\
\hline$R-59 *$ & 0 & 0 & 0 & 0 & 0 & 31 & \pm 2 \\
\hline$R-60^{*}$ & 0 & 0 & 0 & 0 & 0 & 39 & \pm 2 \\
\hline $\mathrm{R}-61 *$ & $* 0$ & 0 & 0 & 0 & 0 & 31 & \pm 2 \\
\hline$R-62$ & 0.33 & 1 & 0. & 0 & 0.33 & 30 & \pm 2 \\
\hline$R-63$ & 4.3 & 15 & 12.4 & 4 & 16.7 & 39 & \pm 2 \\
\hline$R-64$ & 0.6 & 3 & 0 & 0 & 0.6 & 49 & \pm 2 \\
\hline Avg. & 7.6 & 4.5 & 6.1 & 3.5 & 13.6 & 3.0 & - \\
\hline
\end{tabular}

*Batch, other continuous.

Table 2.7 Proportional Bands and Reset Times

\begin{tabular}{|c|c|c|c|c|c|c|c|c|c|}
\hline \multicolumn{2}{|l|}{$\mathrm{Cal}$} & \multicolumn{2}{|c|}{ Evap } & \multicolumn{2}{|c|}{$\begin{array}{l}\text { Evap } \\
\text { Liquid Level }\end{array}$} & \multicolumn{2}{|c|}{$\begin{array}{l}\text { Evap } \\
\text { Temp }\end{array}$} & \multicolumn{2}{|c|}{$\begin{array}{l}\text { Evap } \\
\text { Pressure }\end{array}$} \\
\hline No. $(\mathrm{PB})$ & $\begin{array}{l}\text { (FS) } \\
\text { (min) }\end{array}$ & (FB) & $\begin{array}{l}(\mathrm{RS}) \\
(\mathrm{min})\end{array}$ & $(\mathrm{PB})$ & $\begin{array}{r}(\mathrm{RS}) \\
(\mathrm{min})\end{array}$ & $\begin{array}{l}(\mathrm{PB}) \\
(0)\end{array}$ & $\begin{array}{l}(\mathrm{RS}) \\
(\mathrm{min})\end{array}$ & $\begin{array}{l}(\mathrm{PB}) \\
(\%)\end{array}$ & $\begin{array}{l}(\mathrm{RS}) \\
(\mathrm{min})\end{array}$ \\
\hline$R-42100$ & 5 & 200 & 5 & 20 & 5 & 200 & 5 & 25 & 0.3 \\
\hline$R-43300$ & 50 & 100 & 3 & 25 & 3 & 100 & 3 & 25 & 0.3 \\
\hline $\mathrm{R}-4+300$ & 44 & 200 & 3 & 25 & 1 & 60 & 5 & 20 & 0.3 \\
\hline$R-45 * 300$ & 24 & 200 & 3 & 25 & 4 & 75 & 5 & 20 & 0.3 \\
\hline$R-46 * 300$ & 60 & $M$ & $\mathrm{M}$ & 50 & 10 & 60 & 9 & 20 & 3 \\
\hline$R-47200$ & 40 & 40 & 9 & 25 & 10 & 60 & 8 & 20 & 0.3 \\
\hline$R-48 \cdot 200$ & 50 & 200 & 5 & 25 & 10 & 60 & 9 & 20 & 0.3 \\
\hline$R-49300$ & 0 & 200 & 5 & 25 & 10 & 25 & 9 & 50 & 0.3 \\
\hline$R-50200$ & 0 & 200 & 9 & 25 & 10 & 25 & 10 & 50 & 0.3 \\
\hline $\mathrm{R}-5] * 200$ & 0 & 200 & 9 & M & M & 25 & 10 & 50 & 0.3 \\
\hline$R-52 * 200$ & 0 & 200 & 10 & M & M & 25 & 10 & 20 & 0.3 \\
\hline$R-53200$ & 0 & 200 & 10 & 25 & 10 & 25 & 10 & 20 & 0.3 \\
\hline$R-54 \quad 150$ & 0 & 100 & 2 & 25 & 10 & 25 & 8 & 10 & 1 \\
\hline$R-55 \quad 150$ & 0 & 100 & 2 & 25 & 10 & 25 & 8 & 10 & 0.3 \\
\hline$R-56150$ & 0 & 100 & 2 & 25 & 10 & 25 & 9 & 10 & 1 \\
\hline$R-57 \quad 150$ & 0 & 200 & 10 & 25 & 10 & 25 & 10 & 15 & 1 \\
\hline$R-58200$ & 0 & 100 & 10 & 25 & 10 & 25 & 8 & 10 & 0.1 \\
\hline $\mathrm{R}-59 * 200$ & 0 & M & $M$ & $M$ & M & M & M & 10 & 0.1 \\
\hline$R-60^{*} 100$ & 0 & 100 & 10 & $\mathrm{M}$ & $M$ & 25 & 8 & 25 & 1 \\
\hline$R-61 * 220$ & 0 & M & $M$ & M & M & M & M & 25 & 1 \\
\hline$R-62200$ & 240 & 100 & 10 & 25 & 10 & 100 & 10 & 25 & 1 \\
\hline$R-63200$ & 240 & 100 & 10 & 40 & 10 & 200 & 8 & 25 & 1 \\
\hline$R-64200$ & 240 & 100 & 10 & 40 & 10 & 200 & 10 & 25 & 1 \\
\hline Limits & $-20 \%$ & $S P$ & $5 \%$ & SP & $\pm 20 \%$ & $\mathrm{SP}$ & $5 \%$ & $\mathrm{SP}$ & $=200$ \\
\hline
\end{tabular}

*Batch, other continuous. 
A cell layout for the pilot plant equipment was agreed on. The calciner, evaporator, feed storage tank, feed pump, concentrated feed tank, calciner condenser, condensate hold tank, and fractioning column are to be located in cell 2 of the ICPP Hot Pilot Plant. Cell 1 will contain the fractionator condenser and condensate storage tank along with the racks of stored calciner pots under observation for temperature and pressure buildup. Shielding calculations will determine if unit shielding around the stored pots will be necessary. Substitution of a jet for feeding from the evaporator instead of the proposed air-lift eliminated the need for installing the evaporator in cell 3, which is a deep cell.

Mercury Trap. A trap for removing mercury compounds from the calciner off-gas stream was designed and fabricated for testing in the Unit Operations pilot plant. It is similar to a cyclone made of 6-in.-dia pipe 22 in. long. The 2-in.-dia inlet enters the vessel tangentially. The 2-in.-dia discharge is 6 in. below the inlet along the vessel axis. The trap will condense mercury compounds along the walls by cooling the gas stream well below its $400^{\circ} \mathrm{C}$ inlet temperature. The mercury compounds expected to be deposited are mercuric nitrates, mercuric oxide, and possibly some elemental mercury. A laboratory study is being made to determine the optimum temperature for operating the trap. Nozzles are provided in the trap for spraying the deposited solids with nitric acid after each run to dissolve them for simple disposal to the waste tanks. However, it may be possible to eliminate this wash by maintaining the trap temperature sufficiently low to permit incipient vapor condensation during operation. The walls of the trap may then be washed free of mercury and a disposable solution will result. A nozzle is also provided in the gas inlet to permit steam or water addition to the vapor feed in case of plugging during operation.

Mechanical Test Program. A development program for testing the mechanical operations during pot calcination is underway at the Lockheed Nuclear Products Facility at Georgia Nuclear Laboratories. Equipment design for the filling station and calcination pot was completed at ORNI and sent out for bid. The furnace dolly and mockup were delivered to Georgia Nuclear Laboratories and are currently being installed in their hot cell for testing.

Calculations (3) indicate that the probable internal pressures to cause rupture of an 8-in.-dia type 304L stainless steel pot calciner with a minimum wall thickness of 0.282 in. at a temperature of $1700^{\circ} \mathrm{F}$ are $100 \mathrm{psi}$ for rupture in $100 \mathrm{hr}$, $235 \mathrm{psi}$ for rupture in I hr, and $840 \mathrm{psi}$ for rupture in $5 \mathrm{~min}$. The design criteria for the pots during calcination was set at 10 psi for $100 \mathrm{hr}$ at a calcination temperature of $1700^{\circ} \mathrm{F}$. During final storage of the calcined waste, the criterion is 200 psi at $600^{\circ} \mathrm{F}$ wall temperature, which includes $1 / 8$ in. corrosion allowance. 
The closure test specimens (4) were welded at the Georgia Nuclear Laboratories and are now being leak tested. Environmental conditions during leak testing involve cycling the temperature between 25 and $300^{\circ} \mathrm{C}$ at 150 psi internal pressure to simulate pot storage conditions. To date, leak rates on three of the specimens have been less than 0.2 standard cubic centimeters of helium gas per year determined by a helium mess spectrometer leak detector. This is excellent in comparison to the specified $32 \mathrm{cc} / \mathrm{yr}$ maximum permissible leak rate.

The initial leak test on the Grayloc was unsuccessful because of a visible nick in the Grayloc seal ring, which limited the maximum obtainable vacuum to $40 \mu \mathrm{Hg}$. Replacement of the seal ring permitted a vacukn of $10 \mu \mathrm{Hg}$ to be obtained. Leak rates will be determined under the same environmental conditions used for the welded closures.

Temperature Control During Calcination (S.H. Jury). A mathematical study was initiated to predict the control pattern for a pot during calcination. Calculations showed that during the course of radioactivewaste calcination the temperature throughout the cake that forms along the wall, leaving an internal cavity, in the calciner is less than the wall temperature until the cake reaches a certain critical thickness, dependent on the parameter $Q R^{2} / k$, where $Q$ is the radioactive heat generation rate per unit volume of cake, $R$ is the calciner radius, and $\mathrm{k}$ is the cake thermal conductivity.

It was also shown that as the cake thickness continues to increase beyond critical thickness, the wall temperature of the calciner must be programed (Fig. 2.5) to ensure that all portions of the cake are calcined at $1652^{\circ} \mathrm{F}$ without any portion of the cake exceeding $1652^{\circ} \mathrm{F}$. The program in the figure corresponds to a parameter value that is an average for Darex and Purex wastes and a l-It-aia calciner. The program is based on the assumption that the calciner will be completely filled with cake.

\subsection{Design of Radioactive Cell Equipment ( $\mathrm{H} . \mathrm{O}$. Weeren and J. O. Blomeke)}

Engineering flowsheets and process piping layouts for the hot cell equipment were completed and approved. Process equipment for study of fission product volatility during evaporation and calcination of actual high-activity-level wastes from ICPP and HAPO, is to be assembled on a rack in the ceit: mockup on the third floor of Bldg. 4505, cold tested there, and modified if necessary. When the processing cell becomes available, the equipment will be broker down into three subassemblies and reassembled in the cell.

Because of some uncertainty as to the availability of cell 1 in BIdg. 4507 for this program, alternative locations, cells B-I and B-2 in Bldg. 3026 and the site of the intended self-sintering pilot pit experiment, are being considered. It was concluded that no nodifications would be required to the process equipment to 


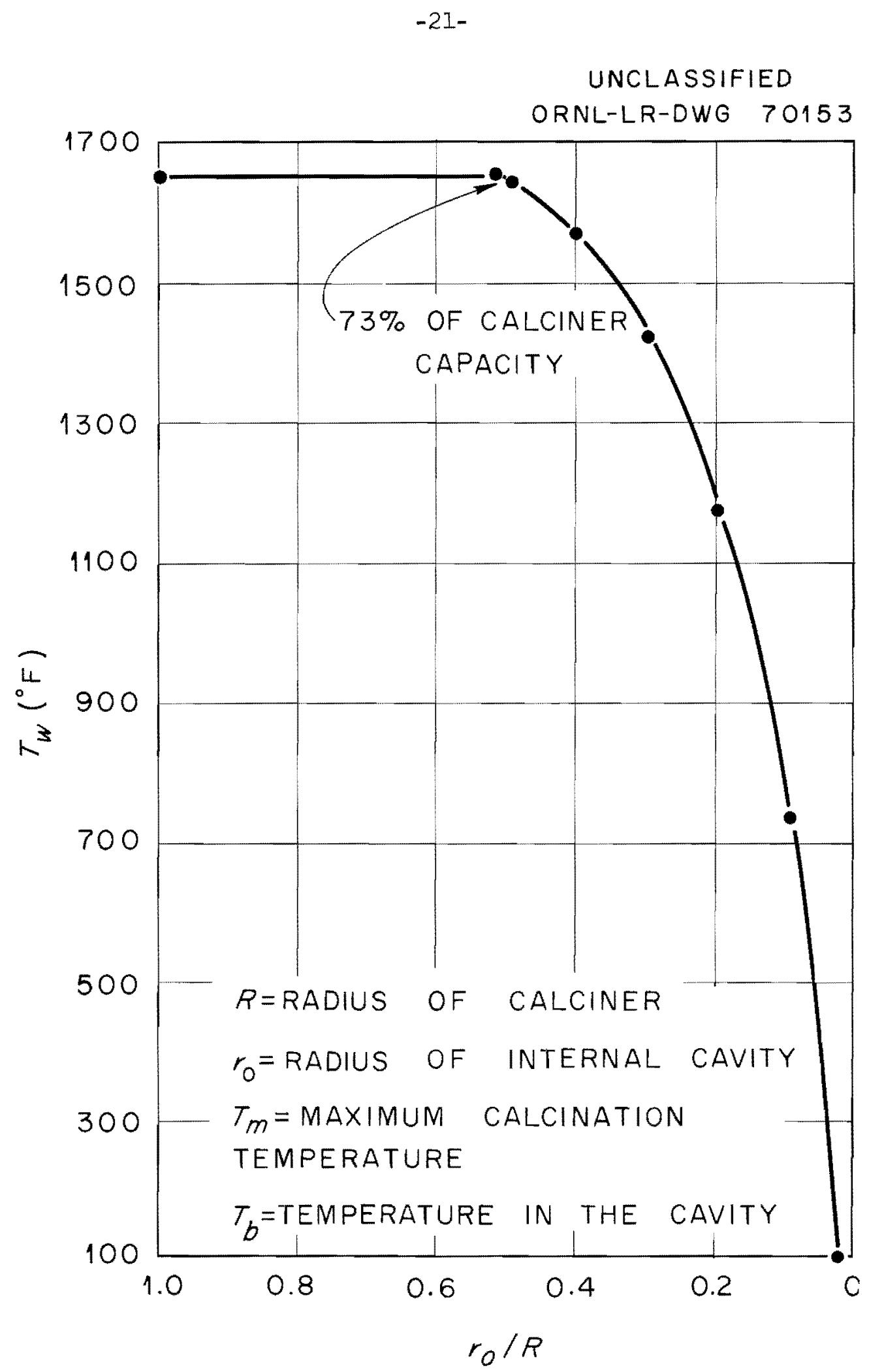

Fig. 2.5. Calciner Wall Temperature $\left(T_{W}\right)$ Program That Ensures Uniform Calcination at $\mathrm{T}_{\mathrm{m}}=1652^{\circ} \mathrm{F}$ as the Solution-Solid Boundary Location, $r_{0} / R$, Moles Inward. $T_{b}=302^{\circ} \mathrm{F}\left(150^{\circ} \mathrm{C}\right) ; \mathrm{QR}^{2} / \mathrm{k}=9250^{\circ} \mathrm{F}$. 
adapt it to operation in BIdg. 3026 but that some modifications or addition to auxiliary equipment would be required. Some modification of process equipment would be required for operation in the selfsintering pilot pit site, the details of which are still under study.

\subsection{Laboratory-Scale Fixation}

Ruthenium Volatility (W. E. Clark). Gillespie still studies of ruthenium volatility during evaporation of acid nitrate solutions confirmed the value of phosphite addition to TBP-25, Darex, and Purex solutions as well as to solutions of pure nitric acid (5) and reconfirmed the well known fact that ruthenium volatility varies with the species present (Table 2.8).

Lowering the distillation pressure from 750 to $570 \mathrm{~mm} \mathrm{Hg}$ did not decrease the ruthenium volatility with respect to that of nitric acid in the absence of aluminum nitrate or other salts. Addition of ruthenium as the nitrosohydroxide instead of the chloride to $6 \mathrm{M}$ $\mathrm{HNO}_{3}$ increased the activity of ruthenium in the distillate from $2 \times 10^{3}$ to $3.76 \times 10^{5} \mathrm{c} / \mathrm{min} . \mathrm{ml}$ and decreased the separation factor of nitric acid from ruthenium from 30 to 0.126 . Addition of $0.1 \mathrm{M} \mathrm{H} \mathrm{PO}_{3}$ to the solution before distillation decreased the activity of volatilized ruthenium to $1.45 \times 10^{2} \mathrm{c} / \mathrm{min} \cdot \mathrm{ml}$ for an initial solution of comparable activity. The separation factor for nitric acid increased to 364. For the solutions studied, the addition of $0.1 \mathrm{M} \mathrm{H}_{3} \mathrm{PO}_{3}$ lowered the ruthenium distillation factor, $\mathrm{Ru}$ (vapor)/Ru(Iiquid), by factors which varied from 38.8 for simulated Darex waste solution to 2920 for $6 \mathrm{M} \mathrm{HIO}_{3}$. The corresponding separation factors for nitric acid were increased by factors varying from 38.4 to 2866 (Table 2.9).

Of the three types of simulated waste solutions studied, aluminum-containing waste (TBP-25) showed the highest separation factors for nitric acid, 4920 with the addition of $0.1 \mathrm{M} \mathrm{H}_{3} \mathrm{PO}_{3}$ and 13.8 without. Corresponding values for Purex and Darex wastes were 2.21 and 117, and 1.49 and 57.4 , respectively. Allowing the Darex solution to stand overnight after the addition of $0.1 \mathrm{M} \mathrm{H}_{3} \mathrm{PO}_{3}$ lowered the separation factor from 57.4 to 38.9 (Tabie 2.8). Apparently some of the phosphite was oxidized on standing.

These data and those previously reported (5) were from experiments carried out under carefully controlied conditions and probably cannot be quantitativeiy reproduced with real process waste solutions. A.lso, the total volume reduction in the present studies was only $6.9 \%$ rather than $30-50 \%$, which may be desired prior to waste calcination. The data show that ruthenium volatility can be reproduced fairly accurately under given conditions, which should allow accurate predictions of the volatility for changes in a given system. The volatilities reported here for solutions containing no phosphite probably represent about the maximum to be expected. In a practical system an appreciable amount of 
Table 2.8 Volotilization of Ruthenium from Nitric Acid Solutions

All feed solutions were $0.002 \mathrm{M}$ in Ru, $\sim 1 \mu \mathrm{Ru}-106 / \mathrm{ml} \mathrm{j}^{\mathrm{a}}$ feed wol $130 \mathrm{ml}$; distillate vol $9 \mathrm{ml}$

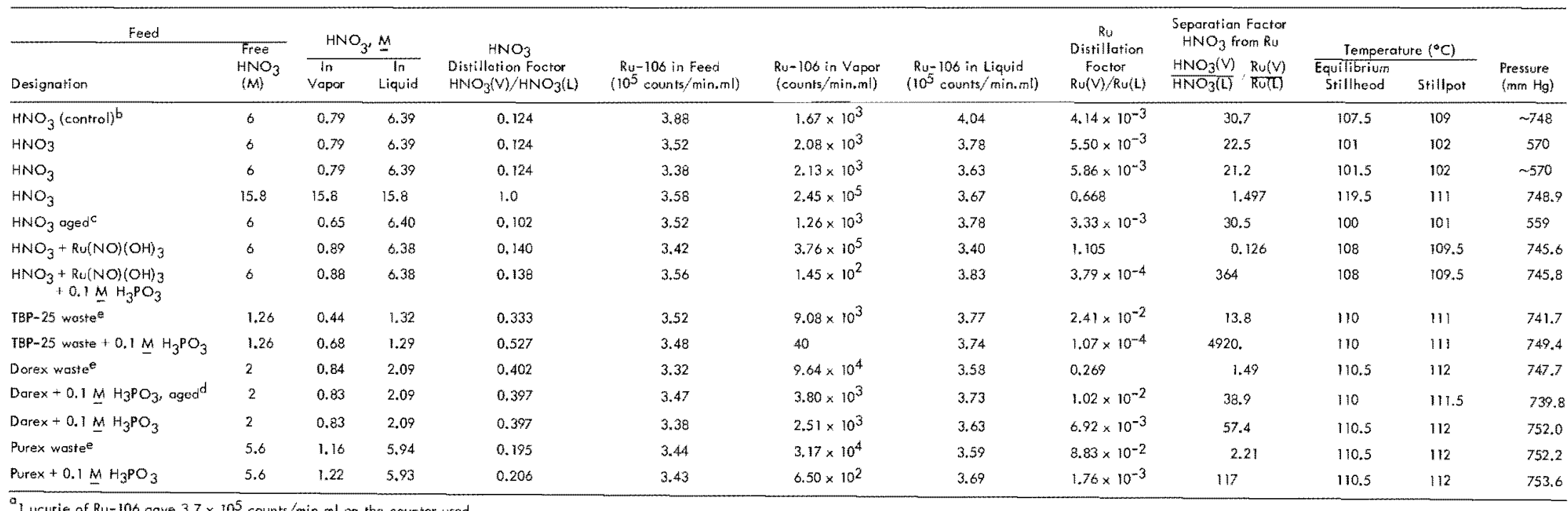

1) pecurie of Ru-106 gave $3.7 \times 10^{5}$ counts/min.ml on the counter used.

Reported in TM-133.

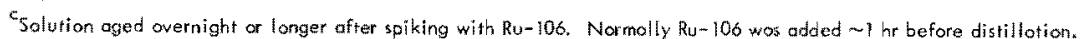

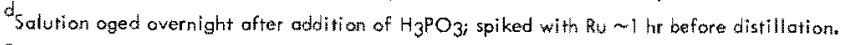

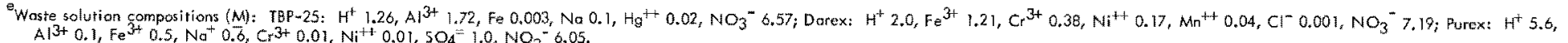


Table 2.9 Effect of $0.1 \mathrm{M} \mathrm{H}_{3} \mathrm{PO}_{3}$ on Volatilization of Ruthenium During Distillation of Nitrate Solutions Ru added as $\mathrm{RuCl}_{3}, 0.002 \mathrm{M}$, except as indicated; all solutions contained $\sim 1 \mu \mathrm{c} \mathrm{Ru}-106 \mathrm{Cl}_{3}$

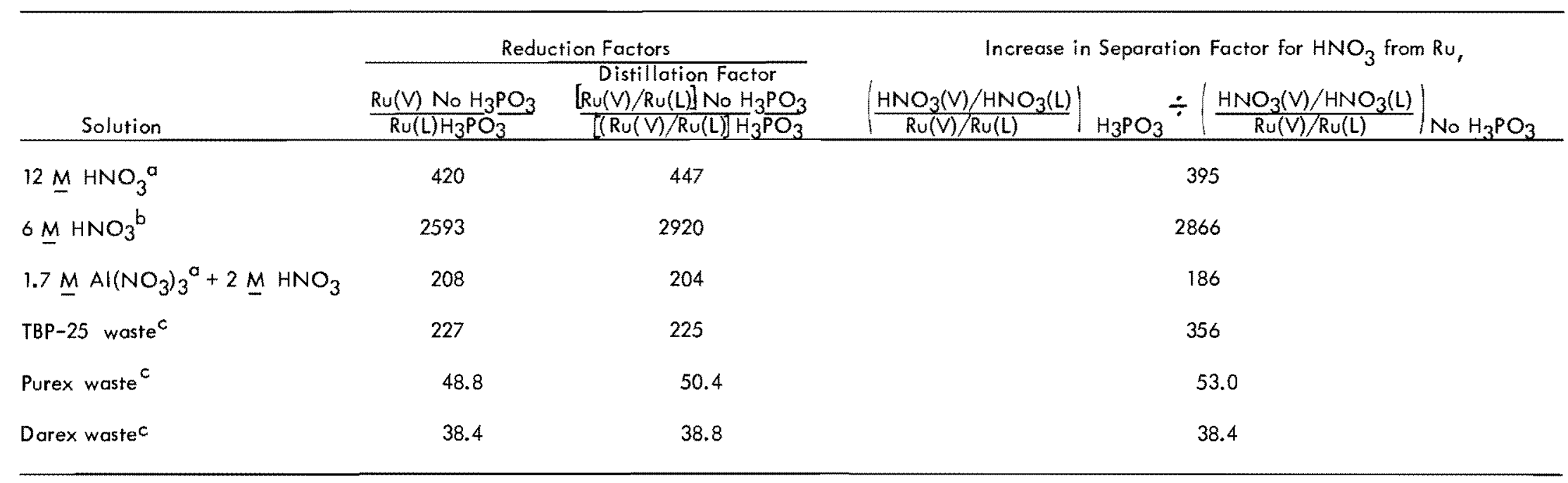

¿Data from ORNL-TM-133, Table 2.2.

${ }^{b}$ Ruthenium added as the nitrosohydroxide.

see footnote to Table 2.8 for solution compositions. 


$$
-25-
$$

volatilized ruthenium will nomally be deposited on the walls of the still pot above the liquid and will therefore not reach the distillate.

Thermal Conductivity (H. W. Godbee). As reported previously, the thermal conductivity of a phosphate-lead glass incorporating TBP-25 waste oxides varied from about $1.05 \mathrm{Btu} / \mathrm{hr} \cdot \mathrm{ft} \cdot{ }^{\circ} \mathrm{F}$ at $300^{\circ} \mathrm{F}$ to about $1.60 \mathrm{Btu} / \mathrm{hr}$. $\mathrm{ft} \cdot{ }^{\circ} \mathrm{F}$ at $1850^{\circ} \mathrm{F}$ (5). Measurements beyond the softening point of the glass, about $1100^{\circ} \mathrm{F}$, gave thermal conductivity values of $1.51 \mathrm{Btu} / \mathrm{hr} \cdot \mathrm{ft}$. $\mathrm{F}$ at $1140^{\circ} \mathrm{F}$ and $1.40 \mathrm{Btu} / \mathrm{hr} \cdot \mathrm{ft} \cdot{ }^{\circ} \mathrm{F}$ at $1150^{\circ} \mathrm{F}$. The thermal conductivity of the glass should be somewhat lower after the glass softens since the liquid state represents a more disordered state. Since the apparatus is not designed to measure the conductivity of fluids accurately, measurements on the molten glass were not continued to higher temperatures.

Semi-continuous Glass Formation. A semi-continuous evaporation, calcination, and heating to $1000^{\circ} \mathrm{C}$ of a simulated TBP-25 waste solution (Table 2.10) containing about $0.1 \mathrm{u} \mathrm{c} / \mathrm{ml}$ Ru-106 and about $2 \mathrm{uc} / \mathrm{mI} \mathrm{Pm}-147$ was carried out in a 24 by 4 -inrdia stainless steel pot. Additives per liter of waste were 2.0 moles $\mathrm{NaH}_{2} \mathrm{PO}_{2}$ and 0.25 mole $\mathrm{PbO}$. Sodium hypophosphite was added to control ruthenium volatility and to serve as a source of phosphate for glass formation. Lead oxide was added to lower the softening point of the product formed. Promethium was added in order to differentiate between volatilized and physically entrained ruthenium.

The equipment (Fig. 2.6) consisted of a stainless steel pot in a 9$\mathrm{kw}$ furnace, a downdraft condenser, packed absorber column, and off-gas jet. The objectives of the experiment were to minimize ruthenium volatility by adding hypophosphite $\left(\mathrm{H}_{2} \mathrm{PO}_{2}^{-}\right)$and to form a phosphate-lead glass with the oxides from the waste solution. As in the previous similar experiment with stable ruthenium only (5) feed was pumped to the pot at an essentially constant rate of about $50 \mathrm{ml} / \mathrm{min}$ with the Iiquid level in the pot gradually rising from about 6 in. above the bottom to about $4 \mathrm{in}$. from the top during the feeding. This method of operation gives, after melting begins, three zones in the pot: a zone of molten glass, a zone of calcining solids, and a zone of evaporating liquid.

Solution analyses showed that $11.5,0.016$, and $52.0 \%$ of the original Ru-106, Pm-147, and mercury, respectively, were in the condensate (Table 2.10). The analyses for Pm-147 show that, of the total ruthenium volatilized, $0.02 \%$ is attributable to physical entrainment. These results with radioactive ruthenium are similar to the previous results (2) with stable ruthenium, $13.7 \%$ of original ruthenium in the condensate. The radioactive ruthenium was determined by gamma counting, while the stable ruthenium was analyzed by neutron activation.

Condensate samples taken at various periods during the evaporationfixation varied rather widely in ruthenium content, indicating that ruthenium volatilization is largely dependent on some operational parameter. This is also indicated by the fact that ruthenium volatility was much lower in batch and small scale continuous experiments (15, I). Attempts will be made to define these parameters in future experiments in order to obtain better ruthenium control. 


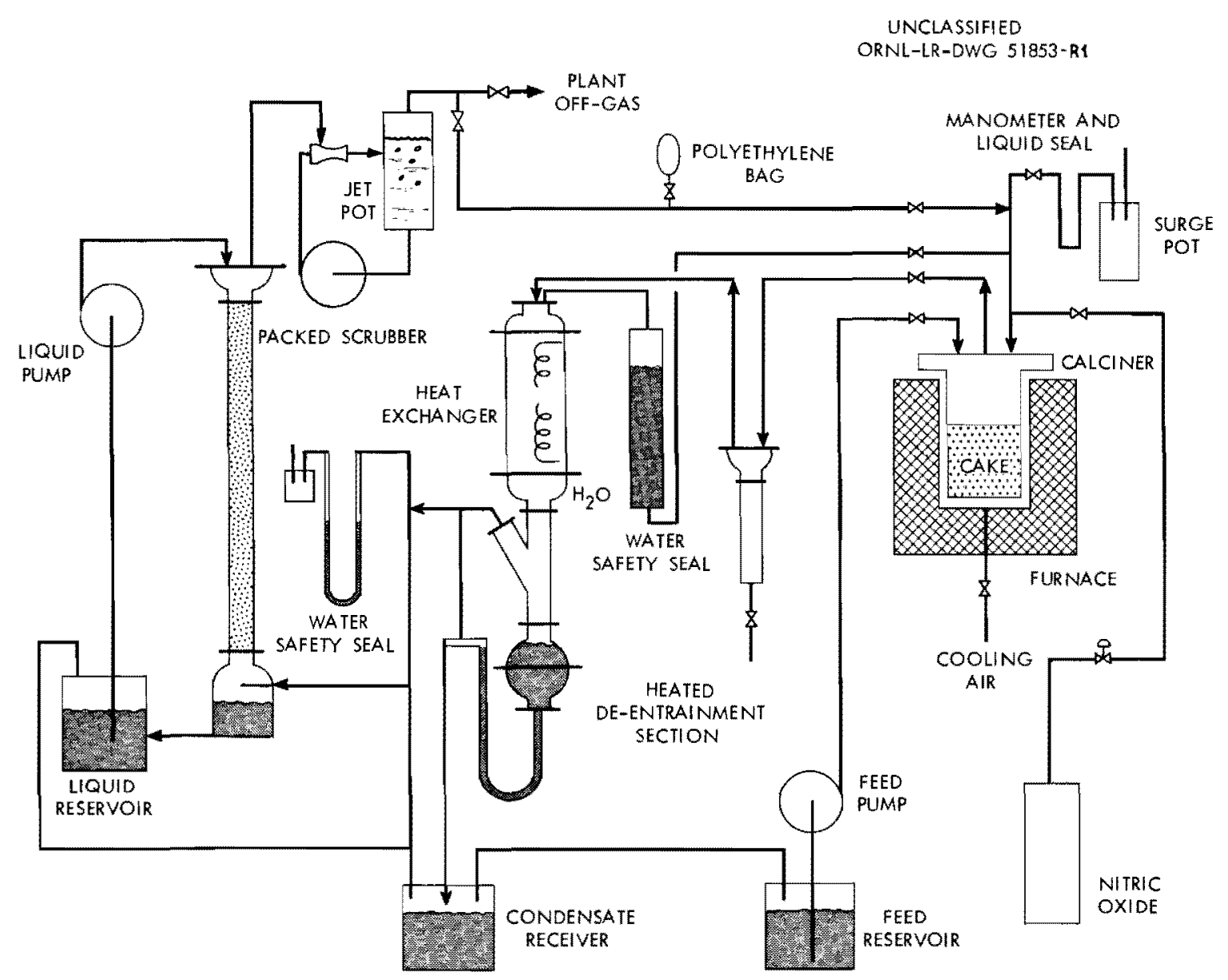

Fig. 2.6. Schematic of Apparatus for Evaporating Calcining and Melting Wastes and Scrubbing Volatile Ruthenium from Off-Gas. 
Table 2.10. System Balances for Semicontinuous Glass Formation at $1000^{\circ} \mathrm{C}$ with TBP-25 Wastes

Waste composition: $1.72 \mathrm{M} \mathrm{Af}^{3+}, 0.16 \mathrm{mg} / \mathrm{ml} \mathrm{Fe}^{3+}, 4.0 \mathrm{mg} / \mathrm{ml} \mathrm{Hg}^{2+}, 2.4$ $\mathrm{mg} / \mathrm{ml} \mathrm{Na}^{+}, 0.05 \mathrm{M} \mathrm{NH}_{4}^{+}, 1.26 \mathrm{M} \mathrm{H}+0.2 \mathrm{mg} / \mathrm{ml} \mathrm{Ru}$, $160 \mathrm{ppm} \mathrm{CI}^{-}, 6.6 \mathrm{M} \mathrm{NO}_{3}$.

\begin{tabular}{|c|c|c|c|}
\hline Constituent & vol, $\mathrm{ml}$ & $\mathrm{dpm} / \mathrm{ml}$ & $\begin{array}{c}\% \text { of } \\
\text { Original }\end{array}$ \\
\hline \multirow[b]{3}{*}{$\begin{array}{l}\text { Feed } \\
\text { Condensate } \\
\text { Secondary off-gas } \\
\text { Jet pot liquid } \\
\text { Recycle liquid }\end{array}$} & \multicolumn{3}{|c|}{ Ru-106 } \\
\hline & $21.0 \times 10^{3}$ & $2.91 \times 10^{5}$ & \\
\hline & $\begin{array}{r}21.2 \times 10^{3} \\
2.4 \times 10^{3} \\
5.5 \times 10^{3} \\
24 \times 10^{3}\end{array}$ & $\begin{array}{rl}3.32 \times 10_{4}^{4} & \\
2.47 \times 10^{4} & 12.8 \\
132 & \end{array}$ & $\begin{array}{l}11.5 \\
0.95 \\
0.001 \\
0.05 \\
12.501\end{array}$ \\
\hline \multirow[b]{3}{*}{$\begin{array}{l}\text { Feed } \\
\text { Condensate } \\
\text { Secondary off-gas } \\
\text { Jet pot liquid } \\
\text { Recycle Iiquid }\end{array}$} & \multicolumn{3}{|c|}{$P m-147$} \\
\hline & $21.0 \times 10^{3}$ & $4.07 \times 10^{6}$ & \\
\hline & $\begin{array}{r}21.2 \times 10^{3} \\
2.4 \times 10_{3}^{3} \\
5.5 \times 10^{3} \\
24 \times 10^{3}\end{array}$ & $\begin{array}{l}6.47 \times 10^{2} \\
2.31 \times 10^{2} \\
5.8 \\
3.7\end{array}$ & $\begin{array}{r}0.016 \\
0.001 \\
.001 \\
0.001 \\
.019\end{array}$ \\
\hline & \multicolumn{3}{|c|}{$\mathrm{Hg}$} \\
\hline Feed & $21.0 \times 10^{3}$ & 4.15 & \\
\hline $\begin{array}{l}\text { Condensate } \\
\text { Secondary off-gas } \\
\text { Jet pot liquid } \\
\text { Recycle liquid }\end{array}$ & $\begin{array}{r}21.2 \times 10^{3} \\
2.4 \times 10^{3} \\
5.5 \times 10^{3} \\
24 \times 10^{3}\end{array}$ & $\begin{array}{l}2.14 \\
0.44 \\
0.02 \\
0.05\end{array}$ & $\begin{array}{r}52.0 \\
0.6 \\
0.1 \\
1.4 \\
54.1\end{array}$ \\
\hline
\end{tabular}

Fixation in Glass. Simulated Darex waste solution was incorporated into melts at $850-1050^{\circ} \mathrm{C}$ (Table 2.11). The products had densities from 2.2 to $3.8 \mathrm{~g} / \mathrm{cc}$ and represented volume reductions varying from 2.9 to 6.6 . The products (except one, melt 6) were glassy only when quenched; when cooled slowly they were crystalline.

Additives, expressed as oxides, used to form melts were $\mathrm{Na}_{2} \mathrm{O}, \mathrm{B}_{2} \mathrm{O}_{3}$, $\mathrm{P}_{2} \mathrm{O}_{5}, \mathrm{Al}_{2} \mathrm{O}_{3}$, and $\mathrm{PbO}$. Sodium hypophosphite was used in all mixes to ${ }^{2} \mathrm{n}$ trol ruthehium volatility. One series to investigate the use of $\mathrm{AlPO}_{4}$ as an additive showed that $\mathrm{AlPO}_{4}$ increased the softening point temperature without improving other properties significantly (F1g. 2.7). 
Table 2.11. Phosphate Melts Incorporating Darex Waste Oxides

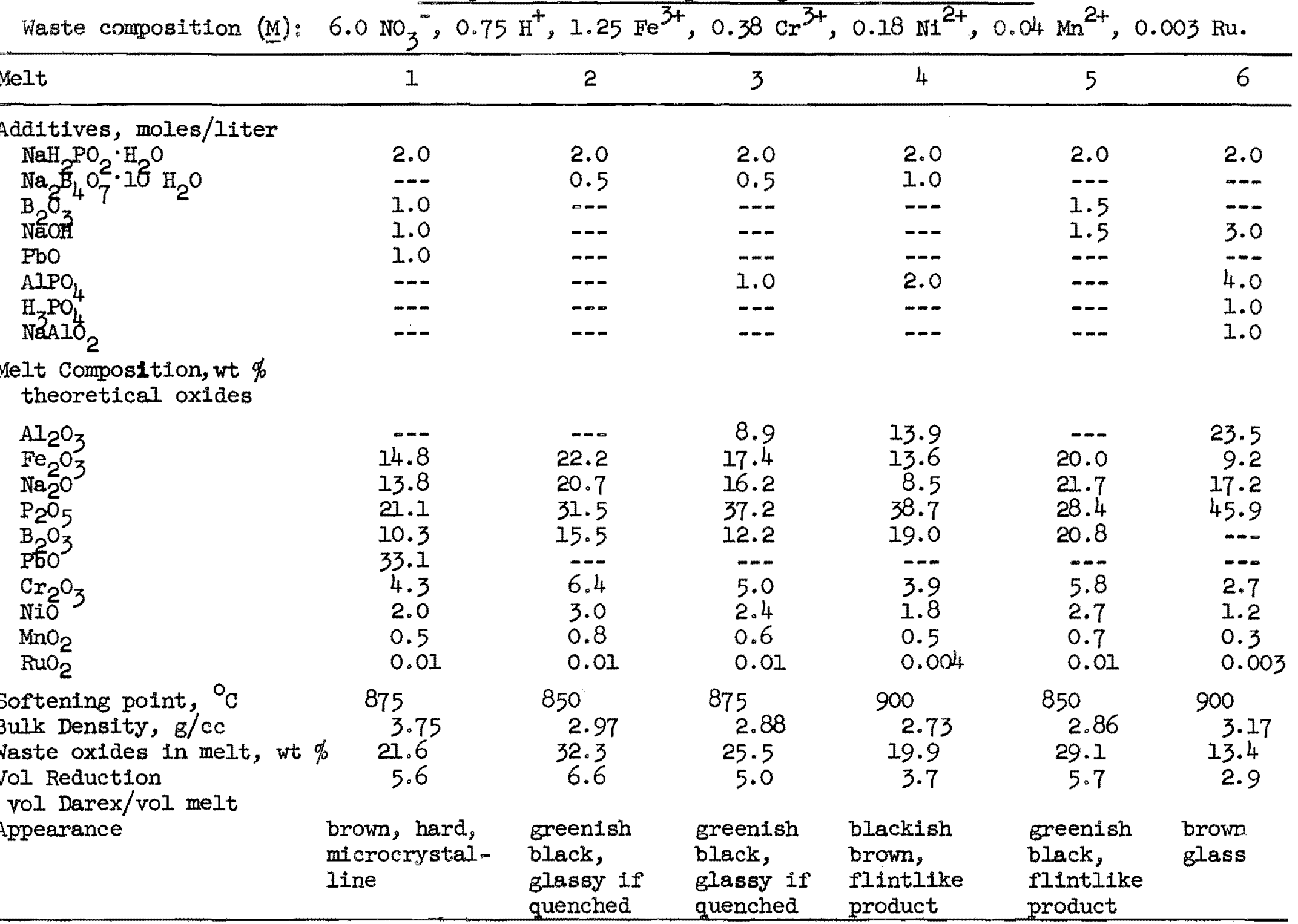




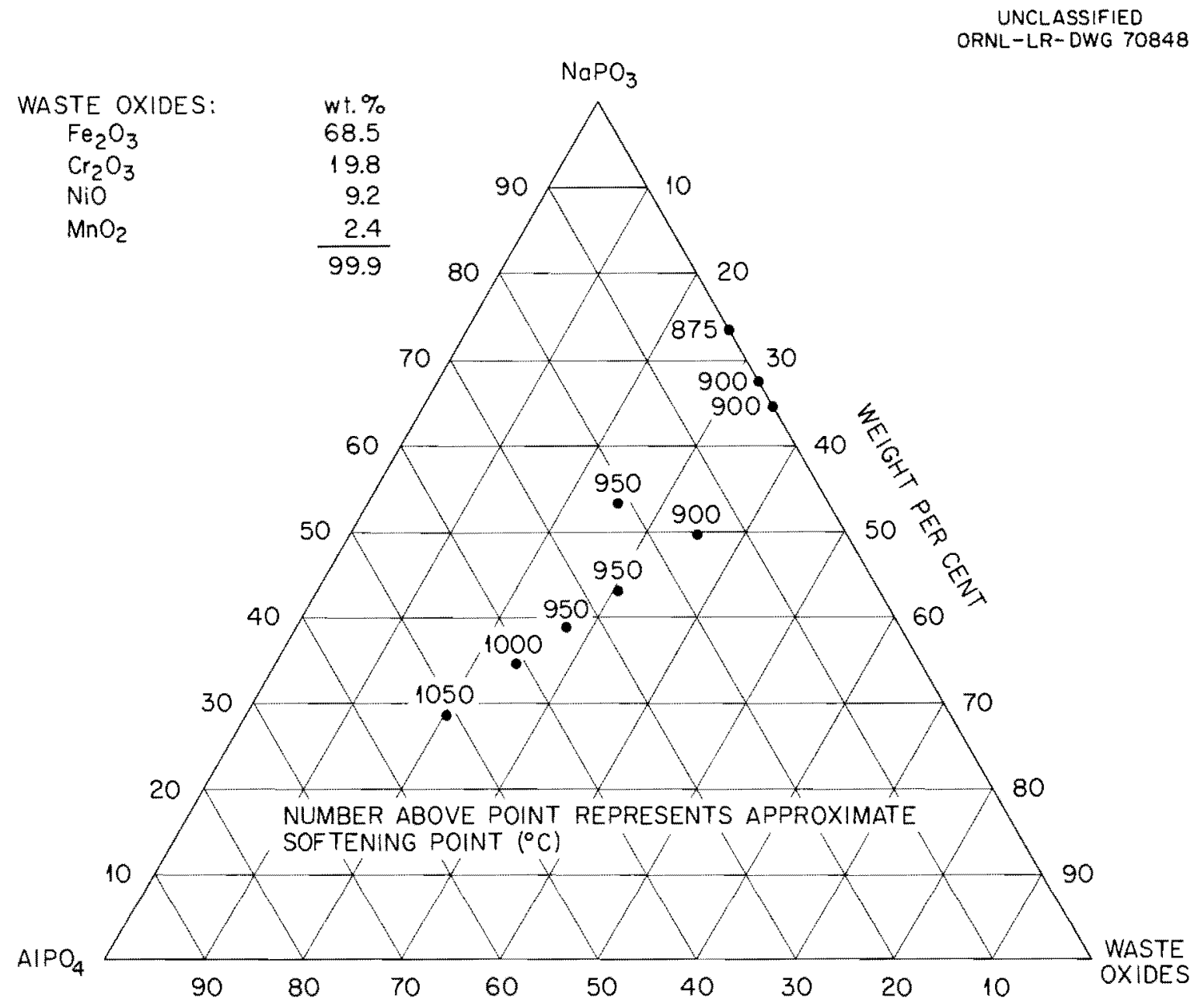

Fig. 2.7. Solid Products Incorporating Darex Waste Oxides. 


\subsection{LOW-LEVEL WASTE TREATMENT}

A scavenging-ion exchange process (6) is being developed for decontaminating the large volumes of slightly contaminated water produced in nuclear installations, with ORNL low-activity-level waste as a medium for study. The scavenging-ion exchange process uses phenolic resins, as opposed to polystyrene resins, since the phenolic resins are much more selective for cesium in the presence of sodium; the Cs/ $\mathrm{Na}$ separation factor is 160 for phenolic groups, and 1.5 for sulfonic groups. Other cations, e.g., strontium and rare earths, are also sorbed efficiently. Inorganic ion exchange media, e.g., vermiculite and clinoptilolite, are being studied as alternatives. The waste solution must be clarified prior to ion exchange since ion exchange media do not remove colloidal materials efficiently. Water clarification techniques are being developed for both the ion exchange processes and for the ORNL lime-soda process waste water treatment plant. Work is proceeding on both development and pilot plant programs.

\subsection{Pilot Plant (R. E. Brooksbank)}

Four demonstration runs were completed (Table 3.1) with ORNL process waste with volumes ranging from 55,000 to $90,000 \mathrm{gal}$, representing 1980-3118 resin bed volumes. Up to 2000 resin bed volumes, the major contaminants, $\mathrm{Sr}-90$ and $\mathrm{Cs}-137$, were removed by factors $>2000$ and $>70$, respectively. Plant effluent contained $<3 \%$ of current $\mathrm{MPC}_{\mathrm{W}}$ values for these isotopes for a $168-\mathrm{hr}$ week. Run durations varied from 90 to $146 \mathrm{hr}$ of continuous operation.

Operation. In a series of four runs, the first (HR-6) was made to ascertain the resin breakthrough point. After 2000 bed volumes of solution had been transferred through the bed, the Sr-90 and Cs-137 decontamination factors (Table 3.1) agreed favorably with other runs in the series. The Cs-137 isotope was the first to break through the resin bed after 2300 bed volumes, with $50 \%$ breakthrough after 2916 bed volumes. (Fig. 3.1). At this point, the plant effluent contained $11.5 \mathrm{~d} \mathrm{~min}^{-1} \mathrm{ml}-1 \mathrm{Sr}-90$, representing $520 \%$ of the $\mathrm{MPC}_{\mathrm{W}}$. At 2711 bed volumes, the total hardness of the resin column effluent increased from $<I$ to $3.5 \mathrm{ppm}\left(\right.$ as $\left.\mathrm{CaCO}_{3}\right)$. It has been established that the hardness breakthrough and $y$-scanning of the resin bed are reliable methods for predicting isotopic breakthrough. Figure 3.1 represents the breakthrough curve plotted from samples analyzed over the 146-hr operating period. Removal factors (Peak activity of isotope during elution $\div$ activity of isotope after 10 bed vol of eluant) for $\mathrm{Sr}-90$ and $\mathrm{Cs}-137$ from the saturated resin bed were $3.14 \times 10^{3}$ and $1.75 \times 10^{3}$, respectively.

In addition to the standard objectives, Run HR-7 was made to observe the performance of the same resin bed used in HR-6 after complete fission product breakthrough. Essentially no ill 
Table 3.1 Removal of Activity from ORNL Waste

\begin{tabular}{|c|c|c|c|c|c|c|c|c|c|c|c|c|c|}
\hline \multirow[b]{2}{*}{$\begin{array}{l}\text { Run } \\
\text { No. }\end{array}$} & \multirow[b]{2}{*}{$\begin{array}{l}\text { Bed } \\
\text { Vol }\end{array}$} & \multicolumn{2}{|c|}{ Gross $\beta$} & \multicolumn{2}{|c|}{ Gross $\gamma$} & \multicolumn{2}{|c|}{$\mathrm{Sr}-90$} & \multicolumn{2}{|c|}{$\mathrm{cs}-137$} & \multicolumn{2}{|c|}{$00-60$} & \multicolumn{2}{|c|}{ TRE } \\
\hline & & $D F$ & $\begin{array}{c}\% \\
\text { Removed }\end{array}$ & $D F$ & $\begin{array}{c}\% \\
\text { Removed }\end{array}$ & $\mathrm{DF}$ & $\begin{array}{c}\% \\
\text { Removed. }\end{array}$ & $\mathrm{DF}$ & $\begin{array}{c}\% \\
\text { Removed }\end{array}$ & $\mathrm{DF}$ & $\begin{array}{c}\% \\
\text { Removed }\end{array}$ & $\mathrm{DF}$ & $\begin{array}{c}\% \\
\text { Removed }\end{array}$ \\
\hline$H R-6$ & 2046 & - & -- & - & -- & 2316 & 99.96 & 543 & 99.82 & - & & & \\
\hline$H R-5^{a}$ & 3118 & 12 & 91.96 & 5 & 77.92 & 20 & 95.11 & 6 & $82 \cdot 30$ & 5 & 80.91 & 21 & 95.33 \\
\hline $\mathrm{HR}-7$ & 2086 & 34 & 97.04 & 19 & 94.71 & 12,160 & 99.99 & 451 & 99.78 & 121 & 91.80 & 24 & 95.77 \\
\hline$H R-8^{b}$ & 2000 & 4 & 71.43 & 3 & 65.21 & 4200 & 99.98 & 3444 & 99.90 & 2.7 & 63.33 & 21 & 95.22 \\
\hline$H R-9$ & 2131 & 26 & 95.4 & 14 & 93.10 & $>8196^{c}$ & 99.99 & $\sim 77$ & 98.70 & 12 & 91.20 & 56 & 98.20 \\
\hline
\end{tabular}

${ }^{a_{A n}}$ extension to breakthrough.

$\mathrm{b}_{\mathrm{High} \text {-activity run. }}$

None of this isotope found in effluent solution by low-activity analysis methods. 


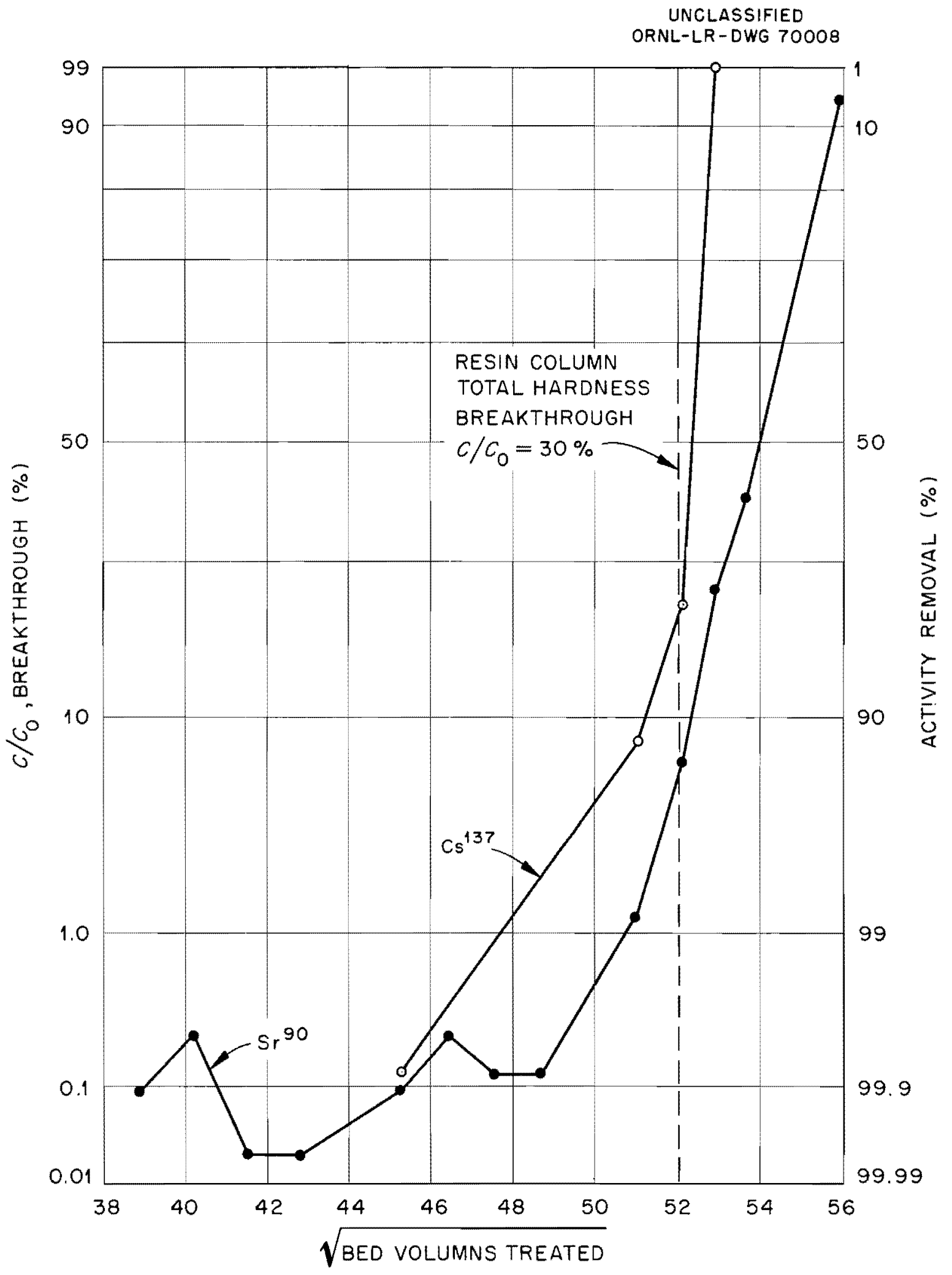

Fig. 3.1. Strontium-90 and Cesium-137 Breakthrough on Duolite Cs-100 Resin (Run HR-6). 
effects were noted; decontamination factors and plant effluent fission product analysis results compared favorably with previous runs. The decontamination factor from $\mathrm{Sr}-90$ in this run was the highest observed to date, $12,160$.

During Run HR-8, the plant received a surge of activity in feed solutions to such an extent that the activity of the sludge blanket increased from 20 to $200 \mathrm{mr} / \mathrm{hr}$ and that of the resin bed from 4 to $18 \mathrm{mr} / \mathrm{hr}$. The major activity was found to be contributed by co-60 $\left(150 \% \mathrm{MPC}_{\mathrm{W}}\right)$, of which $60 \%$ was removed by the process.

Run HR-9 was made with modified sludge withdrawal piping, an inverted flow distributor in the clarifier vessel. These changes were deemed necessary to prevent clogging of the sludge withdrawal holes (3/8-in. dia) in the distribution ring and to provide a more suitable blanket.

Clarifier Hardness Reduction Studies. The major problem of concern in the pilot plant is the excessive total hardness in the clarifier effluent. The average hardness of all runs has been 60-70 ppm (as $\mathrm{CaCO}_{3}$ ). It is hoped that decreasing this hardness will extend the present maximum on-stream life (81-98 hr) of the polishing filters.

Laboratory jar studies with slaked lime as an additive ( $25 \mathrm{ppm}$ ) to ORNL tap water indicated (Sect. 3.2) that a reduction in hardness may be possible, but in run HR-10, with 12.5 to $25 \mathrm{ppm}$ slaked lime, there was no resultant decrease in clarifier effluent hardness. Later laboratory studies indicated that the temperature of the raw feed should be increased from 18 to $24^{\circ} \mathrm{C}$ to effect the hardness reduction. An $8-t^{2}$ heat exchanger has been installed and awaits testing.

At the suggestion of a representative of the Dorr Corporation, a portion of the sludge is being recycled from the clarifier to the llocculator vessel. The total hardness has not been reduced by this change, but the sludge handling characteristics (filterability, blanket distribution, etc.) have been considerably better than previously.

\subsection{Process Development (W. E. Clark, R. R. Holcomb)}

The scavenging-ion exchange flowsheet being used in the pilot plant demonstration program requires that the waste water be made $0.0 .1 \mathrm{M}$ in $\mathrm{NaOH}$ and $5 \mathrm{ppm}$ in iron, the so-called "standard caustic-copperas" treatment. The hardness is decreased to the specified $\sim 10 \mathrm{ppm}$ in the polishing filters by inducing precipitation of $\mathrm{CaCO}_{3}$, which decreases the life of the polishing filters. The laboratory development program has been concerned with breaking the hardness supersaturation, thus allowing removal of hardness in the sludge blanket clarifier and relieving the burden on the filters. Hopefully, an increase in strontium decontamination will accompany the increased calcium removal. A comparison of several treatment methods on ORNL 
tap water in standard jar tests (Fig. 3.2) showed that the best residual hardness was obtained with $50 \mathrm{ppm}$ of $\mathrm{Ca}(\mathrm{OH})_{2}$ and $\mathrm{O} . \mathrm{Ol} \mathrm{M} \mathrm{NaOH}$, the standard caustic-copperas treatment being second. Subsequent tests (Fig. 3.3) showed $25 \mathrm{ppm} \mathrm{Ca}(\mathrm{OH})_{2}$ as optimum with residual hardness 18 ppm or less, but from 12.5 to 50 ppin made very little difference in the resulting water quality. The same relative results were obtained wher $5 \mathrm{ppm}$ of iron was added to a duplicate series; however, the resulting residual hardness was 50-100\% higher. This increase can be explained by a seeding out of precipitate on the $\mathrm{CaCO}_{3}$ particles produced by the rapid reaction of $\mathrm{Ca}(\mathrm{OH})_{2}$ with the bicarbonate ion present in the water. In the presence of iron, a large floc is produced which decreases the surface area of $\mathrm{CaCO}_{3}$ available for seeding. The benefit obtained from the lime addition can be obtained by recirculation of sludge from the clarifier to the fiash mixer, but the seeding effect is not quite so good.

Further investigation of the combination lime-caustic-copperas headend treatment showed the reaction to be temperature dependent. Resiaual hardness was minimum at $26^{\circ} \mathrm{C}$ (Fig. 3.4). A series of jar tests with the standard caustic-copperas treatment demonstrated a temperature dependence of this process, but not below $35^{\circ} \mathrm{C}$.

Other standard jar tests with ORNI tap water showed that the addition of $25 \mathrm{ppm}$ of $\mathrm{CaCO}_{3}$ to the standard caustic-copperas treatment decreased the residual hardness after flocculation from 55 to $38 \mathrm{ppm}$ as compared to $18 \mathrm{ppm}$ obtained with $25 \mathrm{ppm}$ of $\mathrm{Ca}(\mathrm{OH})_{2}$. Varying the bicarbonate alkalinity of the water from a normal 90 porn as $\mathrm{CaCO}_{3}$ to $160 \mathrm{ppm}$ had no effect on the resulting water quality obtained with a lime-caustic treatment.

Variations in the flash mixing time $(0.5,5,10,20$, ana $30 \mathrm{~min})$ had no noticeable effect on caustic or lime-caustic treatment eitre: with or without iron as a flocculent. In actual ORNL waste, treatment with caustic or lime-caustic produced residual hardnesses 50-100\% higher than that of equivalent tap water, very similar to results obtained when 5 ppm of irou was used as a fiocculent with tap water, since the solids present in the waste formed large floc. The addition of $5 \mathrm{ppm}$ of iron in the lime-calistic treatment of tap water increased the resiaual haraness from 19 to $36 \mathrm{ppm}$, while, conversely, the same treatment of actual waste improved the residual hardness from 88 to 55 ppm.

A laboratory-scale sludge blaniret clarifier (Fig. 3.5) containing an inner cone was constructed for dse in rapid evaluation of new process improvements. The unit was operated successfuliy in a preliminary test at a rate of $\sim 250 \mathrm{ml} / \mathrm{min}$ with only $10 \mathrm{~min}$ holdug ir the inner cone. This represents an equipment size rediction of 10 to 20 over the previous laboratory model simulating the pilot plant unit and would result in a corresponding decrease in carital cost of a full-scale plant unit. The unit operating with the standard caustic-copperas treatment and ORNL tap water has croduced water with a residual hardness of $8-12$ pom as $\mathrm{CaCO}_{3}$ in initial test ruris. 


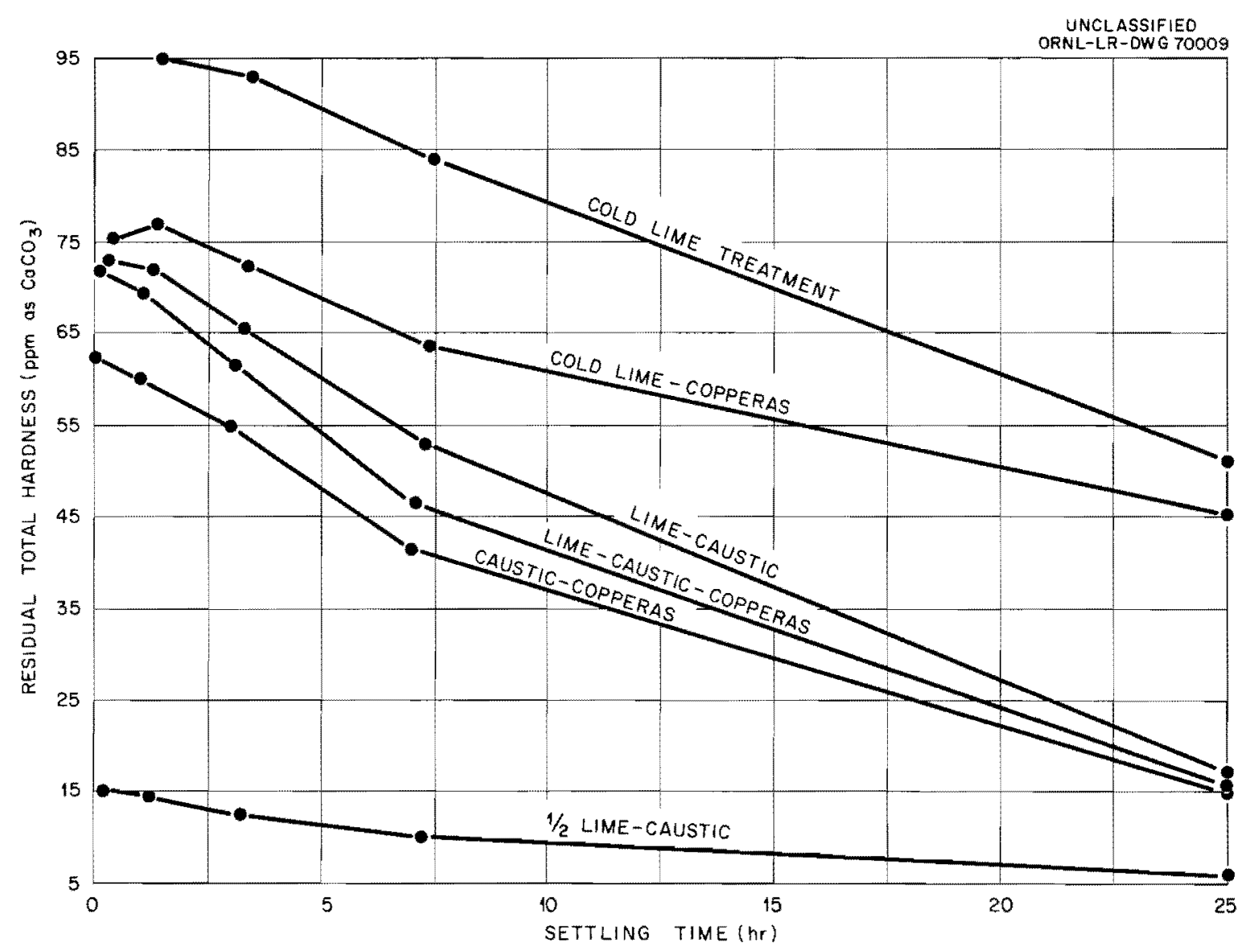

Fig. 3.2. Standard Jar Test Treatment of ORNL Tap Water by Various Methods. TREATMENT CHHMTCALS: Lime - $100 \mathrm{ppm} \mathrm{Ca}(\mathrm{OH})_{2}$; Caustic - $0.01 \mathrm{M} \mathrm{NaOH}$; Copperas - 5 ppm Fe. 


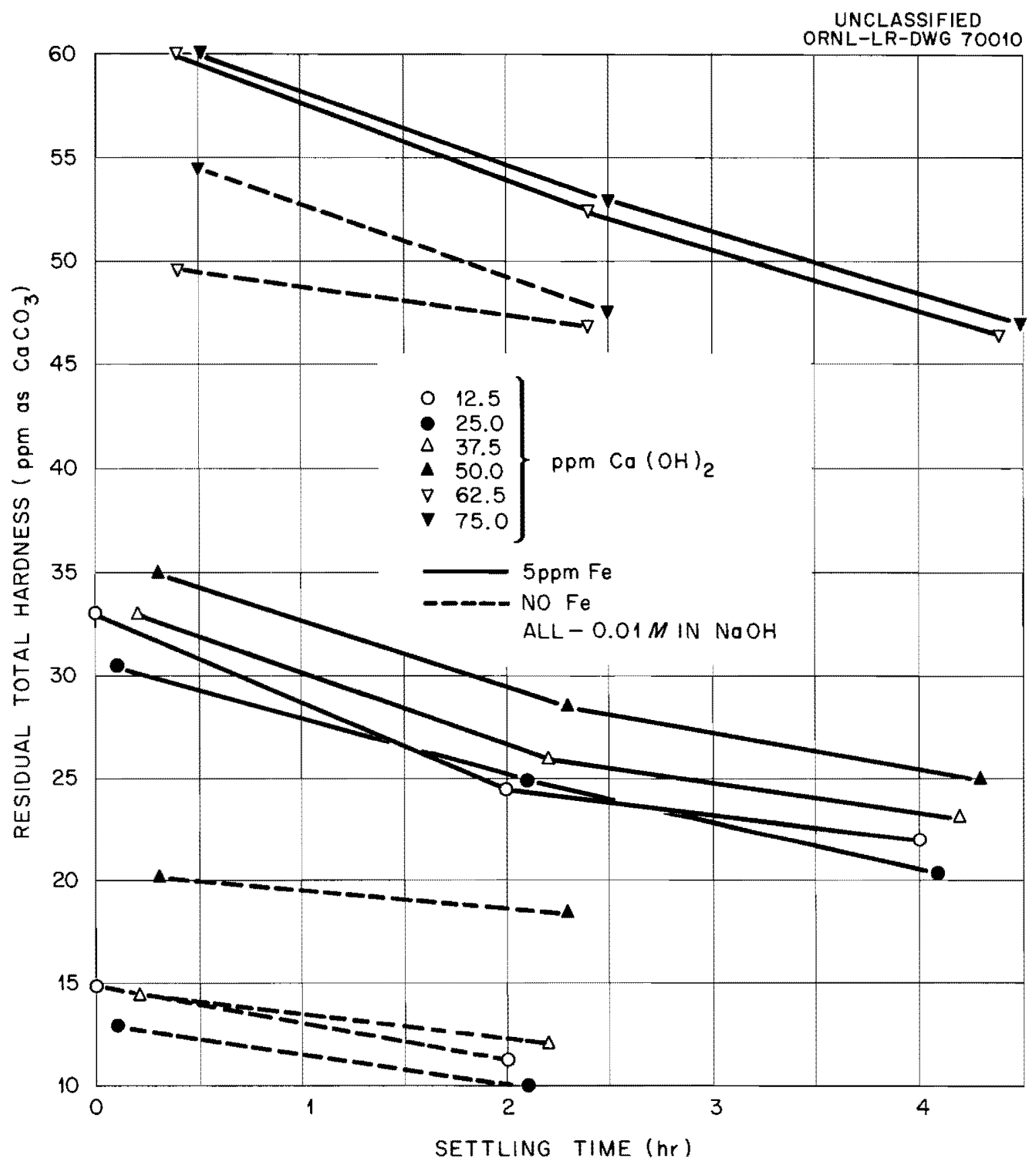

Fig. 3.3. Determination of Optimum Lime Addition to ORNL Tap Water in Standard Jar Tests. 


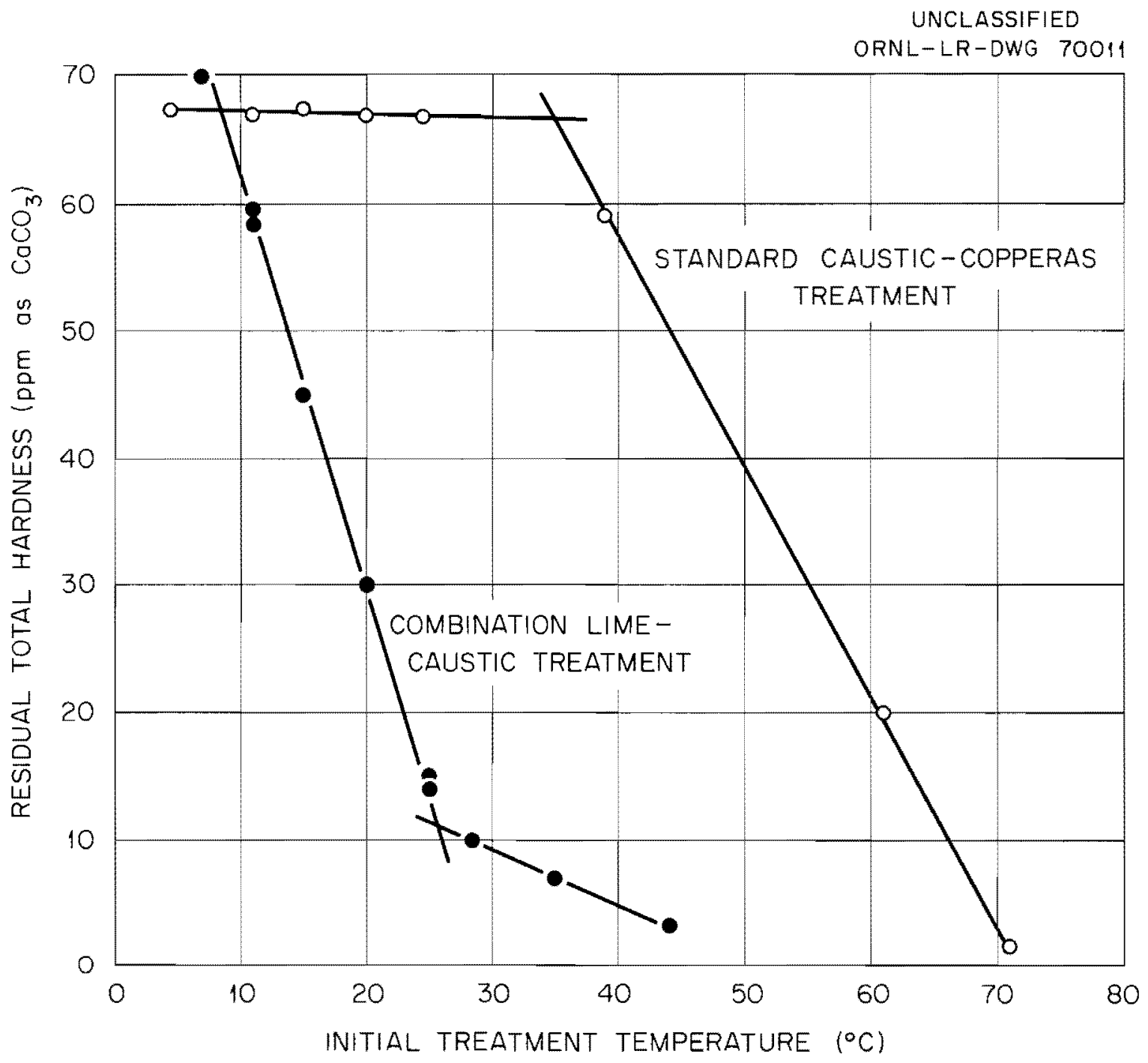

Fig. 3.4. Dependence of Effectiveness on Temperature in Treatment of ORNL Tap Water in Jar Tests. 


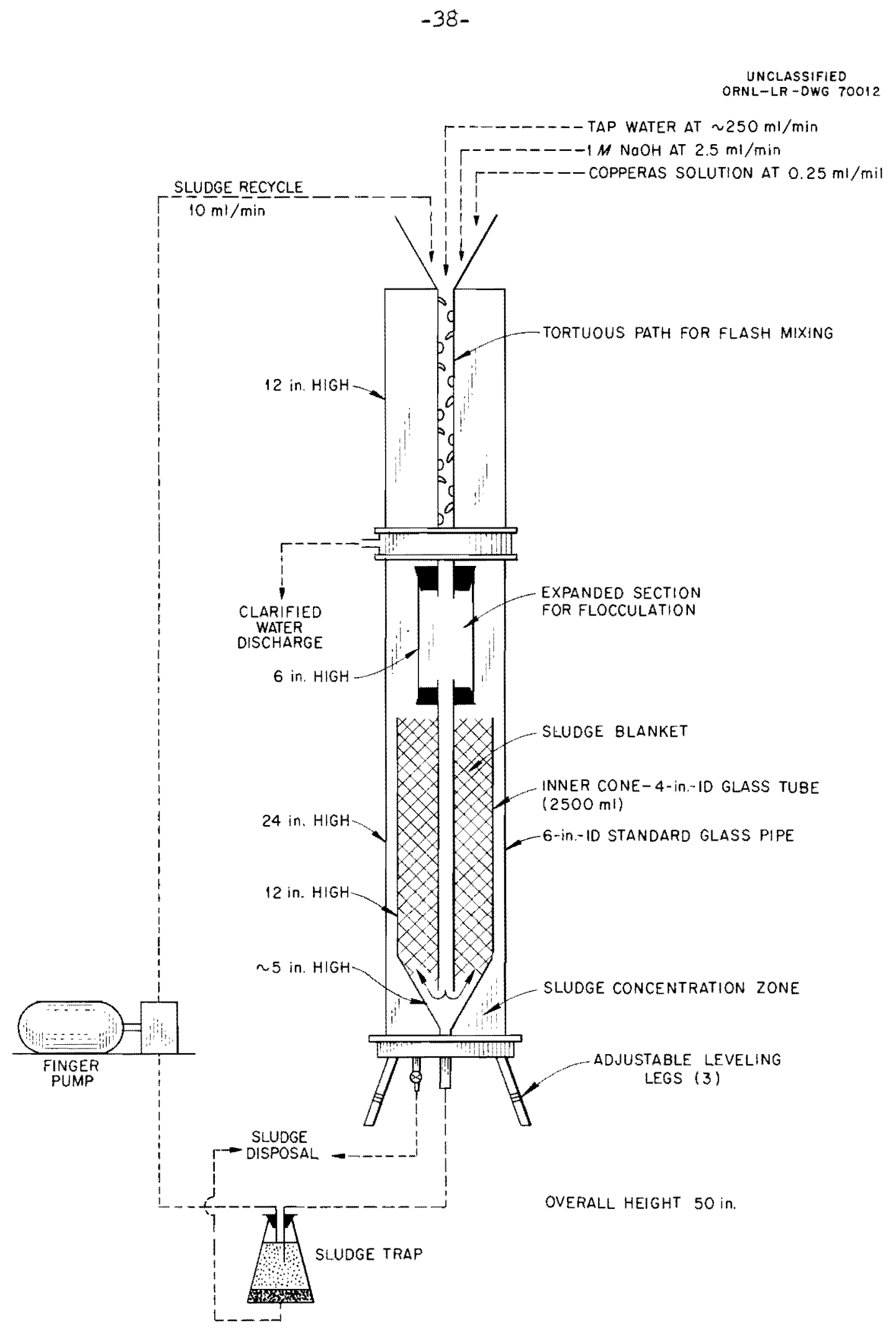

Fig. 3.5. Laboratory Sludge Clarifier. 


\subsection{ENGINEERING, ECONOMICS, AND HAZARD EVALUATION}

R. I. Bradshaw, J. J. Perona, J. O. Blomeke

A comprehensive study has been undertaken to evaluate the economics and hazards associated with alternative methods for ultimate disposal of highly radioactive liquid and solid wastes. All steps between fuel processing and ultimate storage will be considered, and the study should define an optimum combination of operations for each disposal method and indicate the most promising methods for experimental study.

Based on previously reported $(4,5)$ calculations of salt mine space required to dissipate the heat from liquid and solid wastes a conceptual design of a disposal facility in salt for solid wastes was developed to serve for preliminary cost estimation. In addition, as the first part of a transportation study, thermal calculations were made for carriers required for shipment of pot-calcined solids.

\subsection{Economics of Solids Disposal in Salt}

In order to determine which variables are important contributors to the cost of storage of solids in salt mines, a conceptual design was developed and some preliminary cost figures were estimated. A more detalled design and cost estimate will be based on these considerations.

In the conceptual design, the waste container shipping cask is removed from a rail car and carried into a hot cell (Fig. 4.1) that encloses the top of the vertical mine shaft. The waste containers are then unloaded in a storage area, from which they are lowered down the shaft into a motorized carrier at the working level of the mine.

The carrier then moves out to the current disposal area (F1g. 4.2), lowers the container into a hole in the floor, and backfills the hole with fine crushed salt. Concurrently with this operation, salt is being mined in another corridor. The I-mile-square disposal area is assumed to be served by one set of shafts, and the operation will be conducted so that the salt mining is completely isolated from the disposal operations. Disposal operations personnel and equipment will use the mining shaft for the ingress and egress, however. The criteria of isolation and ventilation require that a double tunnel be driven completely around the quadrant and that the rooms on the outside of the peripheral tunnel be excavated before disposal operations start. Ventilating air will come down a compartment in the mining shaft, with a portion being split off into the disposal tunnel. The disposal tunnel air will travel completely around the quadrant and exist up the waste shaft. The air will be drawn from the shaft, through the hot cell and an absolute filter, and up a 200-ft stack. 


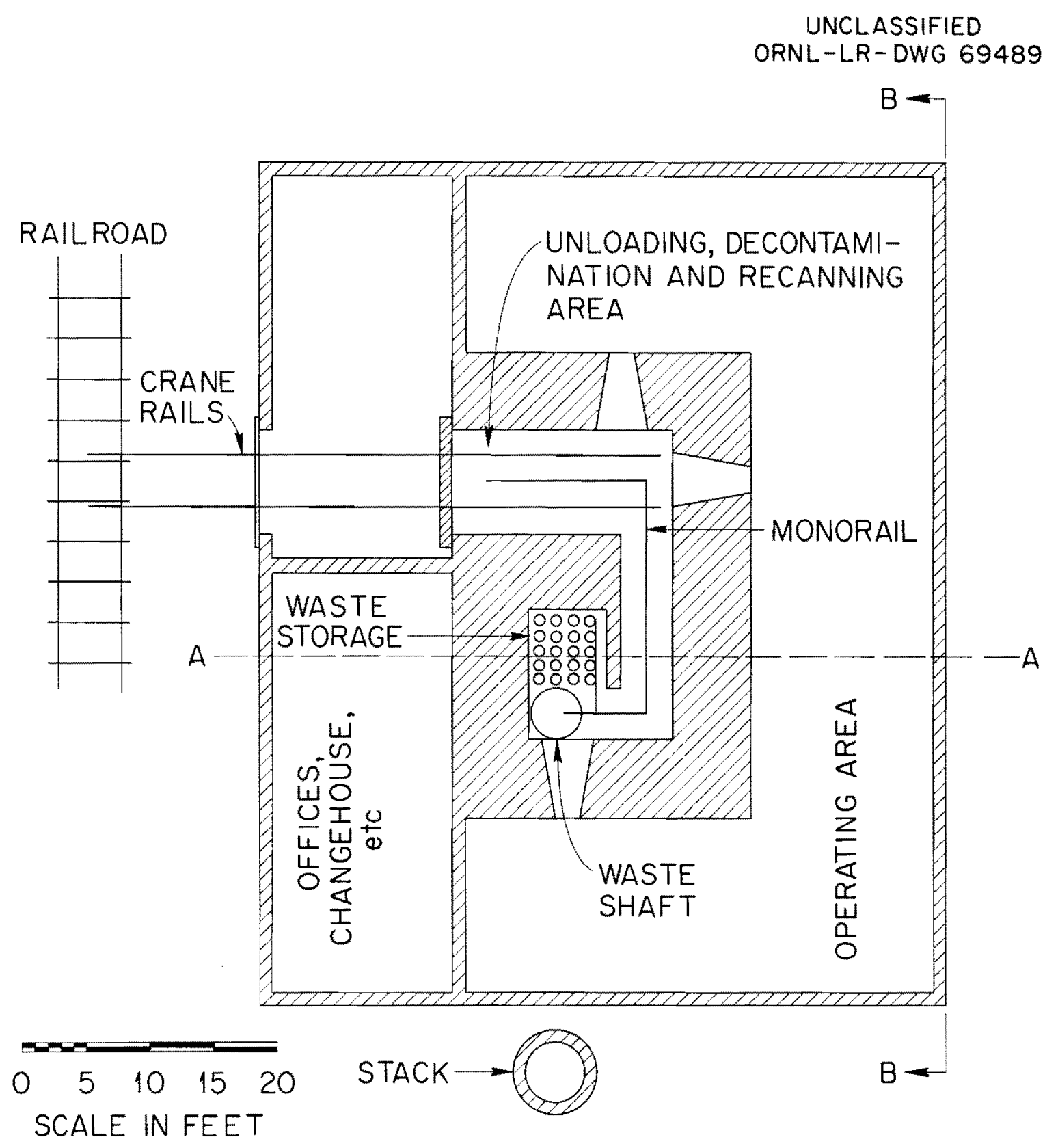

Fig. 4.1. Plan View of Waste-Shaft Surface Facility. 


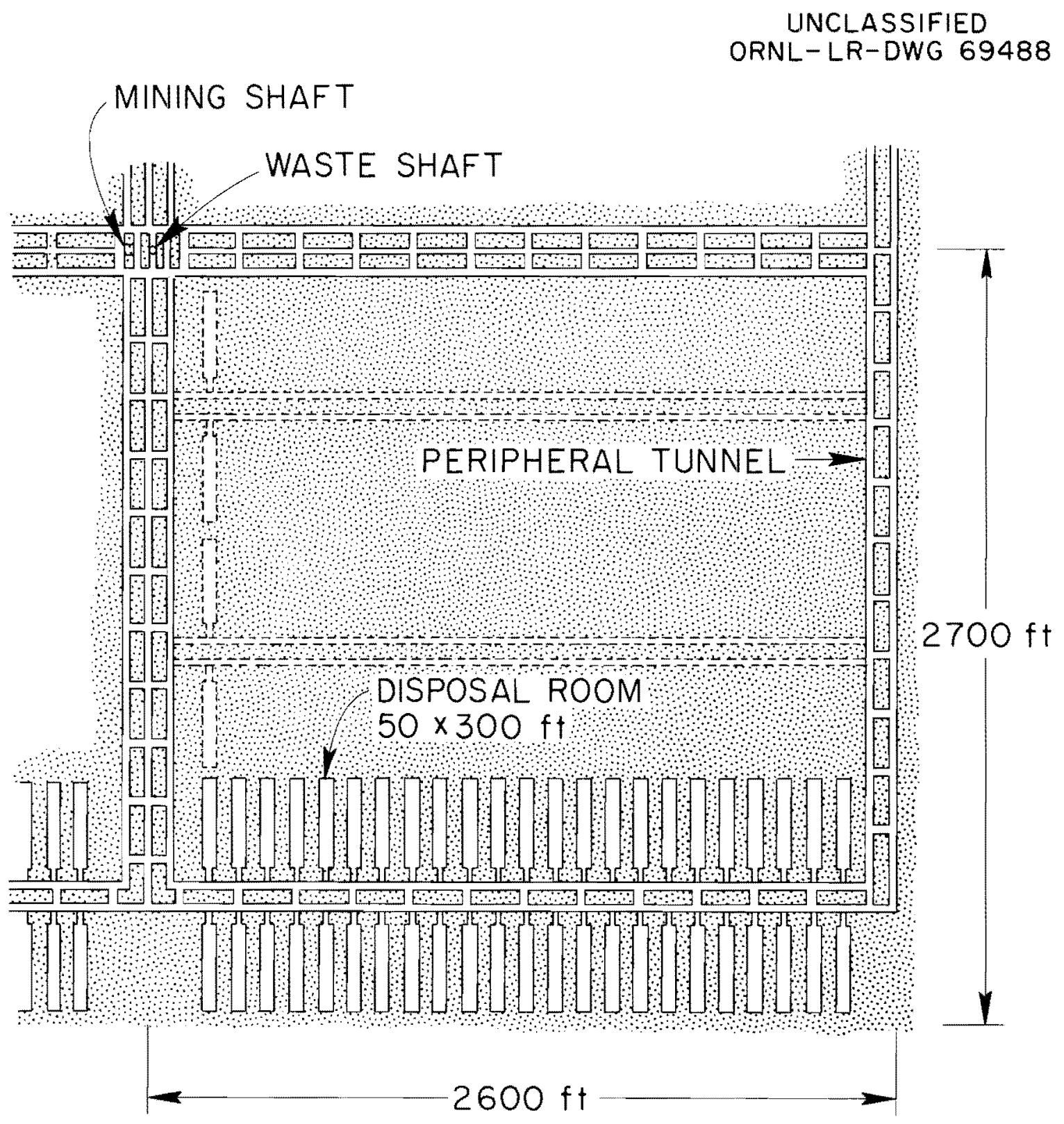

Fig. 4.2. Plan View of One Quadrant of 1-Mile Disposal Area. 
In order that ventilating air shall never pass a hot storage area before it reaches the current working area, disposal operations will start at the most remote point and work back toward the shaft. One quadrant will be filled at a time.

The net yearly space requirements for storage of the various waste combinations were given previously (5). The gross requirements are dependent on the allowable salt extraction for a specified room stability condition. If no fission product heat should be involved, the extraction as a function of depth and stability criteria developed in sect. 6.0 of this report would be adequate. With the presence of heat, the dimensional changes of the rooms due to thermal expansion and plastic flow must also be considered. The problem of predicting the thermal closure of a cavity in salt has not been completely resolved, but an approximate calculation was made for purposes of this study.

Cost figures were calculated for disposal at a depth of 1000 ft for two conditions of stability, one with very small structural flow and 2.5\% dimensional closure due to thermal flow, and one with considerable structural f'low and 100\% thermal closure of the rooms. These figures for typical waste combinations are shown in Table 4.1 for waste ages at burial of $1,3,10$, and 30 years. The costs of developing peripheral tunnels and storage space are based on an assumed cost of $\$ 2$ per ton for salt removal. Shafts and life-of-shaft items were amortized over the time required to fill the entire square mile ( 8.5 years for 1 year's decay with $2.5 \%$ closure to 89 years for 30 years' decay with $100 \%$ closure). Other items were amortized over 10, 20, or 50 years.

Total costs ranged from $6 \times 10^{-3} \mathrm{mill} / \mathrm{kwh}$ for $100 \%$ room closure with 30 -year-decayed wastes to $30 \times 10^{-3} \mathrm{mill} / \mathrm{kwh}$ for 1 -year-decayed and $2.5 \%$ closure. Sixty to $85 \%$ of the total costs were incurred by salt removal, indicating that it is important to get more accurate figures for this item. It might be possible to sell the salt, thus decreasing these costs. Of the remaining costs, only operating appears to be appreciably more important than the others.

\subsection{Shipment of Calcined Solids}

Heat-transfer calculations were carried out to determine waste ages and permissiole carrier sizes in the absence of refrigerating equipment or liquid coolants. Shipping carriers were assumed to be right circular cylinders, with the inner diameter of each carrier and the number of waste cylinders contained by it determined by the necessity of keeping calcined solid temperatures below the maximum calcination temperature of $1650^{\circ} \mathrm{F}$. Waste cylinders were assumed held in square arrays (Fig. 4.3). A spacing structure would be required to hold the cylinders in the array as shown.

Heat transfer between cylinders in the array and between cylinders and the inner surface of the carrier was calculated as 
Table 4.1 Cost of Storing Waste in Holes in Floor of Mine at Depth of 1000 ft for Representative Cases

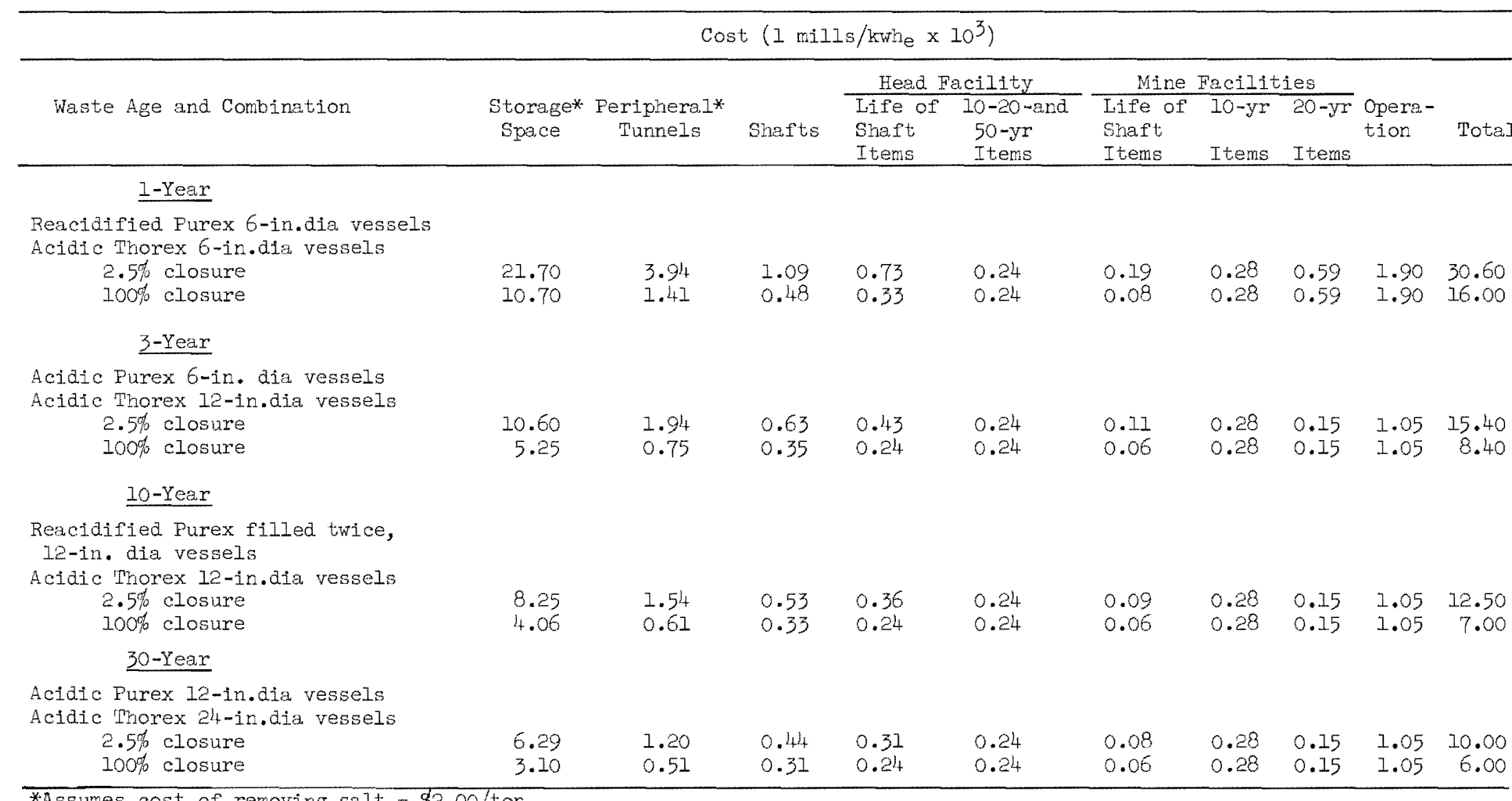

*Assumes cost of removing salt $=\$ 2.00 /$ ton 
$-44-$
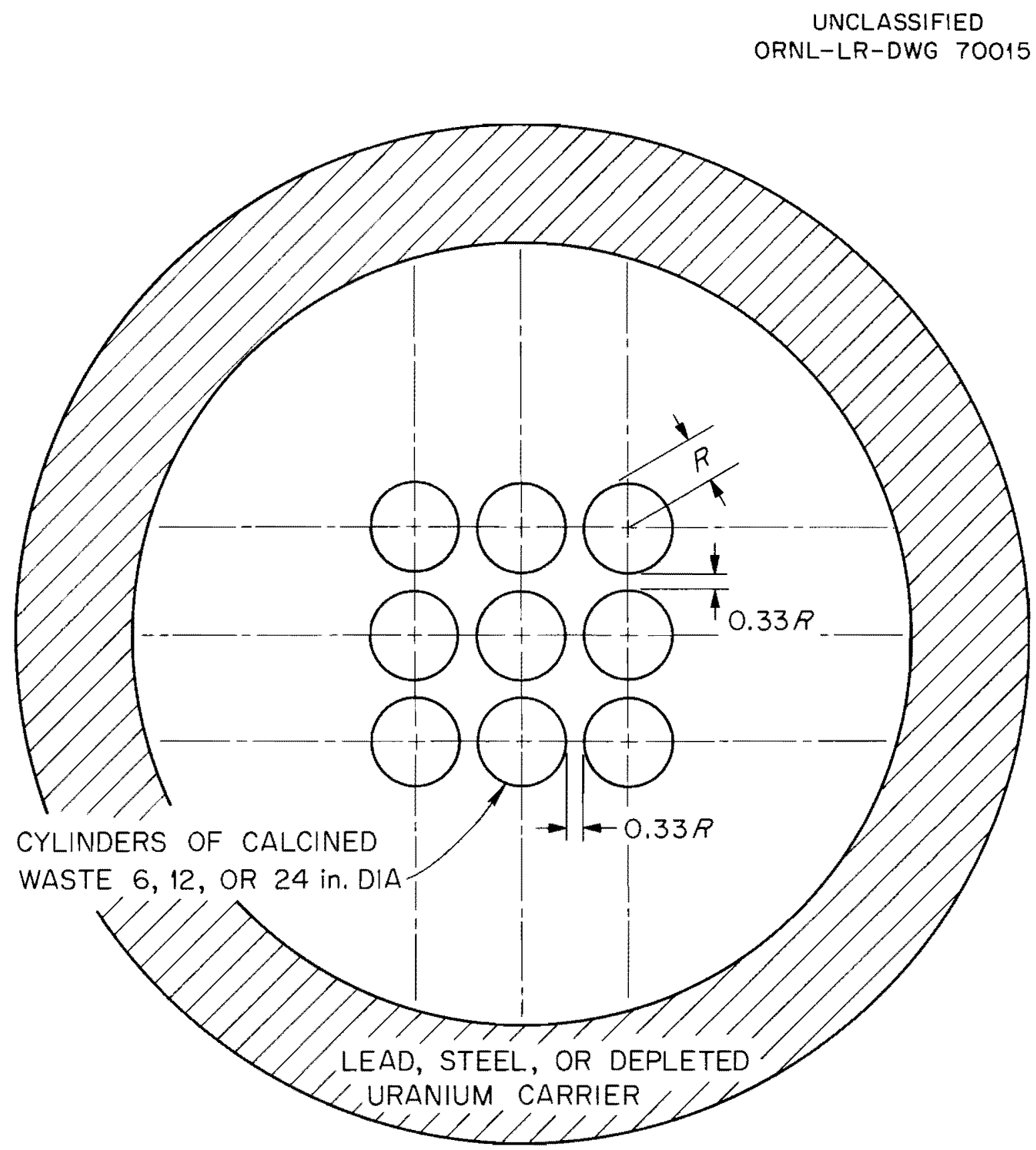
Wastes.

Fig. 4.3. Plan View Sketch of Carriers for Cylinders of Calcined 
if radiant heat transfer alone was contributing. Cylinders were assumed to have radially symmetric temperature distributions. The conservative procedure of neglecting convective heat transfer and conductive heat transfer through the spacing structure tends to compensate for the less than perfect thermal conductivity of the waste, which would tend to impose secondary asymmetric temperature gradients on the cylinders. Temperatures in the carriers were calculated by methods developed in a study of heat transfer in spent reactor fuel rod assemblies (7). Temperature differences across the carrier wall are small enough that the different thermal conductivities of lead, iron, and uranium do not appreciably affect the final results.

The results of the calculations for 6 and 12-in.-dia cylinders are shown in Fig. 4.4, where the maximum number of cylinders per carrier is shown as a function of age of waste for the various waste types. Acidic Purex can be shipped at less than 2 years of age if fewer than nine 6-in.-dia cylinders per carrier are shipped. A carrier for more than thirty-six 6-in. -dia cylinders or nine 12-in.-dia cylinders would weigh more than 100 tons and was assumed to be unmanageably large. The use of fins was assumed to effectively double the outer surface of the carrier. Thirty-six cylinders of acidic Purex waste can be shipped in a single carrier at 2.9 years of age or 2.4 years of age if the outer surface of the carrier is finned. The maximum numbers of $6-$ and 12-in:dia cylinders of reacidified Thorex waste can be shipped at 0.33 year.

Up to four 24-in. -dia cylinders can be shipped in a carrier weighing less than 100 tons. Minimum ages for four 24-in.-dia cylinders are 13 years for acidic Purex ( 11 years finned), 3.5 years for acidic Thorex, 3.4 years for reacidified Purex, and 0.9 year for reacidified Thorex.

These minimum shipping ages in the absence of mechanical cooling are sufficiently close to minimum burial ages that the expense of mechanical cooling to permit earlier shipping will be justified in only a few cases.

\subsection{DISPOSAL IN DEEP WELLS}

\subsection{Disposal by Hydraulic Fracturing}

\subsubsection{Waste Mix Studies (T. Tamura)}

Slurries of simulated waste, portland cement, and additives are being investigated by a Laboratory subcontractor, Westco Research, a subsidiary of The Western Company in Fort Worth. The first objective has been to gain a general understanding of the properties of these slurries and to determine the limits of pumpability. Some of the properties measured were consistency, setting time, fluid loss and compressive strength, in most cases by techniques recommended by the American Petroleum Institute (ㅇ). The slurries 


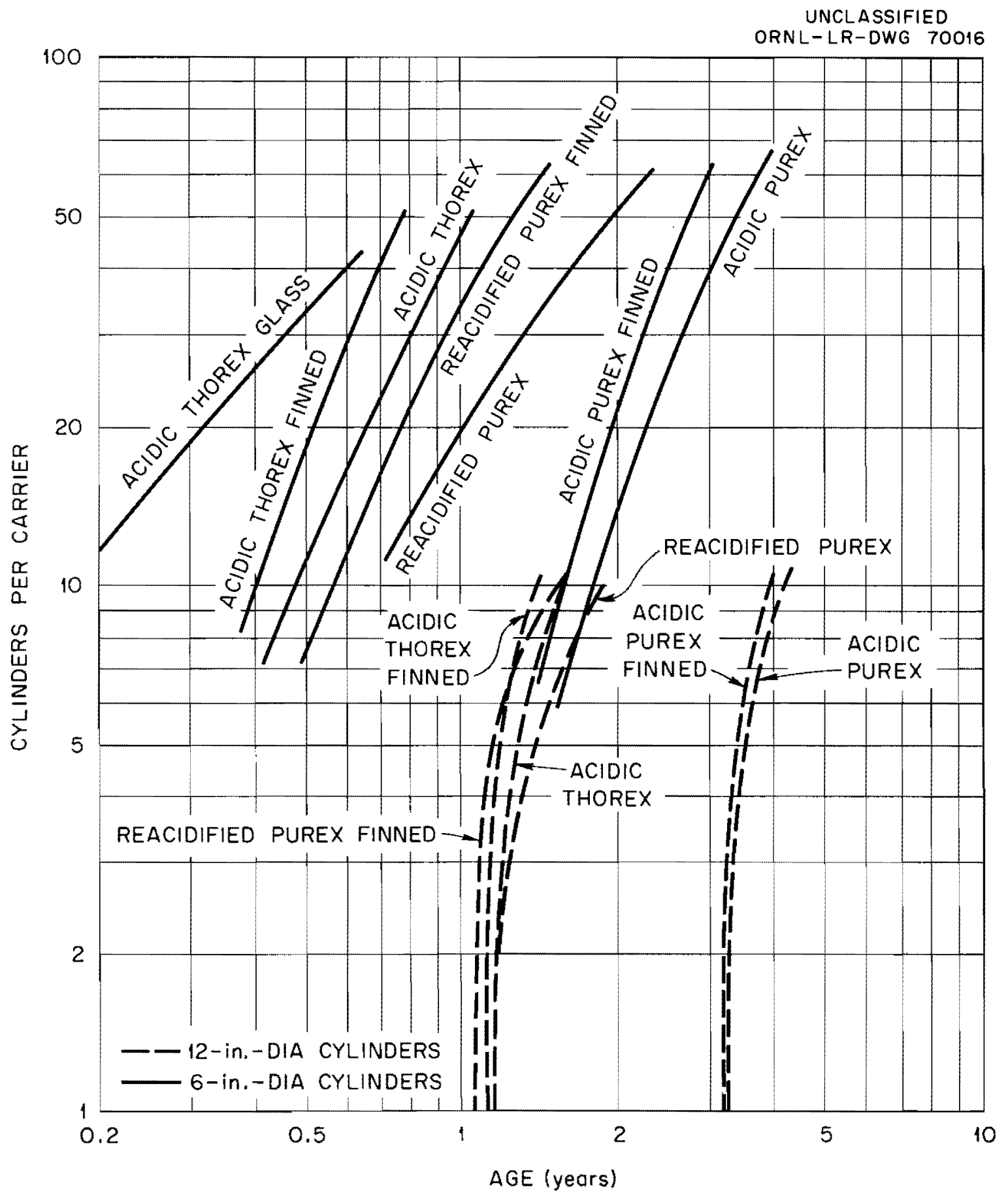

Fig. 4.4. Maximum Permissible Number of Cylinders per Carrier as a Function of Age of Waste to Keep Calcined Solids Temperature Below $1650^{\circ} \mathrm{F}$. 
are made up of cement from different sources and a simulated waste approximating ORNL intermediate-activity-level waste.

Waste-Cement Slurries. After being mixed in a Waring blender, the slurry is visually inspected for evidence of flash setting, initial gel strength, and viscosity. Flash setting and high initial gel strength are dependent on the chemical composition of the cement and the waste solution, and viscosity is affected by the solution-to-cement ratio and initiel hardening processes. Slurries prepared with distilled water as the fluid were easily and thoroughly mixed. Slurries had a high initial gel strength when prepared from Volunteer type I cement and $208 \mathrm{cc}$ of waste solution per pound of cement but not when the proportions of waste solution were larger (Table 5.1). Apparently, close attention will have to be given to the chemical composition of waste and the ratio of waste to cement in designing the ultimate mix. Further studies are underway to identify the constituent(s) in the waste responsible for this initial hardening reaction. A solution cement ratio of $208 \mathrm{cc} / 454 \mathrm{~g}$ is recommended by API for slurries prepared from distilled water and type I cement.

Table 5.1 Quality of Waste-Cement Slurries after Blending

\begin{tabular}{|c|c|c|c|c|c|}
\hline $\begin{array}{l}\text { Cement } \\
\text { Source }\end{array}$ & Solution Used & $\begin{array}{l}\text { Solution } \\
\text { to Cement } \\
\text { Ratio } \\
(\mathrm{cc} / \mathrm{g}) \\
\end{array}$ & $\begin{array}{c}\text { Flash } \\
\text { Setting }\end{array}$ & $\begin{array}{c}\text { High } \\
\text { Initial } \\
\text { gel } \\
\text { Strength } \\
\end{array}$ & $\begin{array}{l}\text { Pour- } \\
\text { ability }\end{array}$ \\
\hline $\begin{array}{l}\text { Trinity } \\
\text { Cement Co. } \\
\text { Dallas, Texas }\end{array}$ & $\begin{array}{l}\text { Distilled water } \\
\text { Distilled water } \\
\text { Distilled water } \\
\text { Waste }\end{array}$ & $\begin{array}{l}208 / 454 \\
170 / 454 \\
163 / 454 \\
208 / 454\end{array}$ & $\begin{array}{l}\text { no } \\
\text { no } \\
\text { no } \\
\text { no }\end{array}$ & $\begin{array}{l}\text { no } \\
\text { no } \\
\text { no } \\
\text { no }\end{array}$ & $\begin{array}{l}\text { yes } \\
\text { yes } \\
\text { no } \\
\text { yes }\end{array}$ \\
\hline $\begin{array}{l}\text { Volunteer } \\
\text { Cement Co. } \\
\text { Knox., Tenn. }\end{array}$ & $\begin{array}{l}\text { Distilled water } \\
\text { Waste } \\
\text { Waste } \\
\text { Waste }\end{array}$ & $\begin{array}{l}208 / 454 \\
208 / 454 \\
220 / 454 \\
245 / 454\end{array}$ & $\begin{array}{l}\text { no } \\
\text { no } \\
\text { no } \\
\text { no }\end{array}$ & $\begin{array}{l}\text { no } \\
\text { yes } \\
\text { no } \\
\text { no }\end{array}$ & $\begin{array}{l}\text { yes } \\
\text { no } \\
\text { yes } \\
\text { yes }\end{array}$ \\
\hline
\end{tabular}

Pumpability Tests. Permissible pumping time is one of the most important properties of the waste-cement slurry. The Pan American thickening-time tester simulates conditions of temperature and pressure at a well depth of $2000 \mathrm{ft}$ at $91{ }^{\circ} \mathrm{F}$ bottom-hole temperature and 1540 psi bottom-hole pressure. The value reported as pumping tine is the time during which the viscosity of the slurry is less than 100 poises. Increasing the volume of waste from 208 to $245 \mathrm{cc}$, increased the pumping time from approximately $2-3 / 4$ to 3-3/4 hr (Table 5.2). The latter value is equal to that when $208 \mathrm{cc}$ of distilled water is used. Increasing the sodium nitrate concentration in the synthetic waste solution from 0.3 to $3 \mathrm{M}$, increased the pumping time to $8 \mathrm{hr}, 20 \mathrm{~min}$. These tests also suggeste $\vec{d}$ that the 


$$
-48-
$$

waste composition will have a strong influence on slurry characteristics.

Table 5.2 Pumpability of Waste-Cement Slurries

\begin{tabular}{ccc}
\hline $\begin{array}{c}\text { Volunteer Cement } \\
(\mathrm{Ib})\end{array}$ & $\begin{array}{c}\text { Waste Solution Vol } \\
(\mathrm{cc})\end{array}$ & $\begin{array}{c}\text { Pumping Time } \\
(\text { hr:min) }\end{array}$ \\
\hline & & $3: 40$ \\
2 & 490 & $3: 15$ \\
2 & 440 & $2: 45$ \\
2 & 416 & $8: 20$ \\
2 & $416 *$ & $3: 43$ \\
\hline
\end{tabular}

*3 $\mathrm{M} \mathrm{NaNO}_{3}$ solution.

**Distilled water.

Although the upper limit of 100 poises is used to calculate the thickening time, this viscosity is far too high for pumping. In most cases the viscosity for pumping is held below $20-25$ poises.

Compressive Strength Tests. Although the importance of compressive strength in the set grout is not yet clear, compressive strength tests are important for determining the effect of additives on the final grout. The compressive strength was much more sensitive to waste composition when the grout was cured at a higher temperature (Fig. 5.I). It remains relatively constant over a wide range of compositions when cured at $80^{\circ} \mathrm{F}$. These mixes contain only waste solution and cement; no additives have been added. Additives such as bentonite, fly ash, and pozmix are often used to keep the cement suspended in the mix during setting; such additives tend to decrease the compressive strength of the set grout.

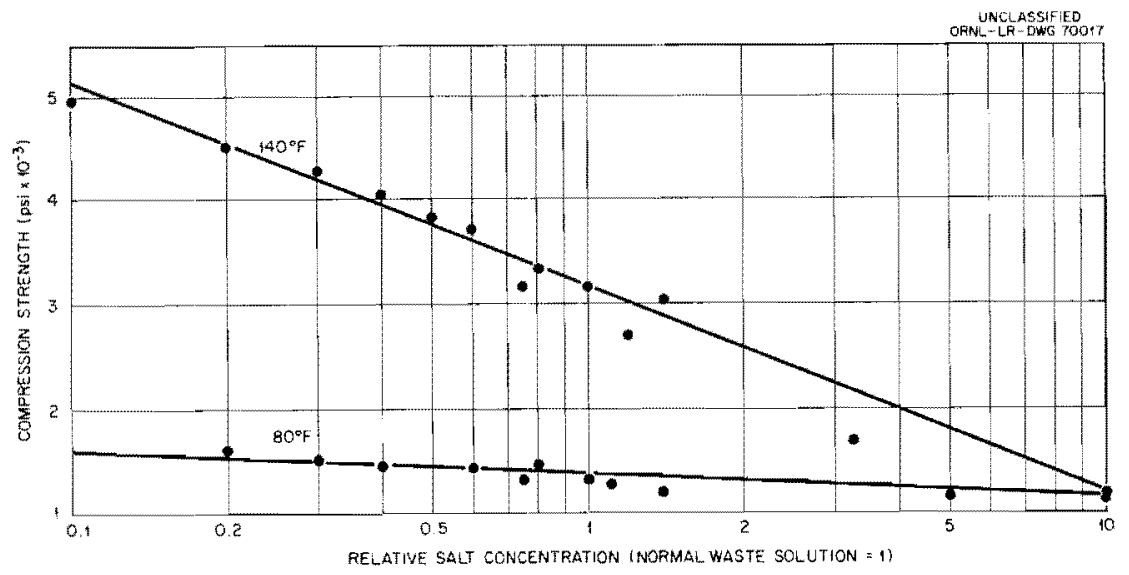

Fig. 5.1. Effect of Waste Composition on the 24-hr Compressive Strength of Grout at 80 and $140^{\circ} \mathrm{F}$ Curing Temperatures. Grout made from 1 Ib of Volunteer Cement Type II and $208 \mathrm{cc}$ of Waste Solution. 
Sulfate ion concentration is detrimental to the compressive strength of set cements; in the oil-well cementing industry, special cements are used whenever sulfates are encountered in groundwater. Simulated ORNL intermediate-activity-level waste, which contains about $0.04 \mathrm{M}$ sulfate ions gave a cement with a lower compressive strength than did distilled water, and excess sulfate corresponding to that in the same waste concentrated by a factor of 10 decreased the strength still more (Fig. 5.2).

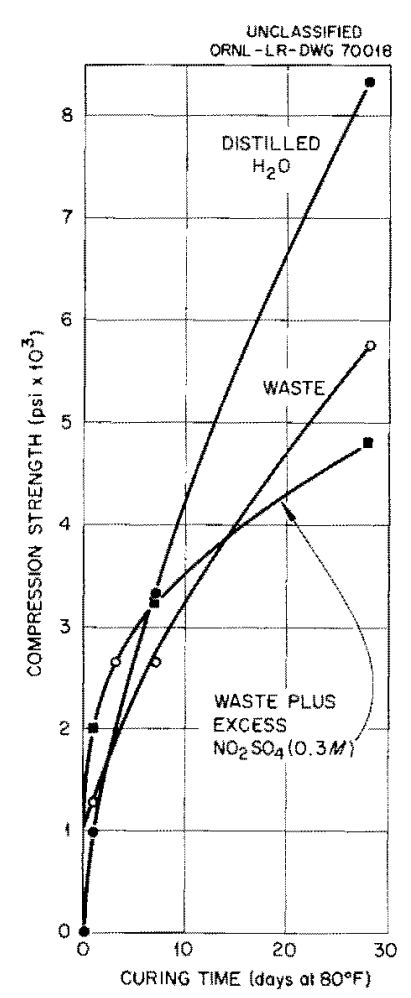

Fig. 5.2. Compressive Strength During Short-Term Curing of Cement.

Since the set grout will be subject to triaxial loading in the shale formation, methods for studying the effects of triaxial loading on properties of the set grout are being advised.

Fluid Loss Additives. The purpose of a fluid-loss additive is to decrease leakage of fluid from the slurry when it is subjected to high confining pressures in the fracture. If hairline cracks are formed during fracturing, liquid may migrate from the slurry into the pores of contiguous rock, and the liquid-deficient grout will set faster. Premature setting will limit the extent of the fracture and possibly decrease the volume of slurry that can be injected.

In the study of the effect of fluid loss, the additive of a proprietary material, $\mathrm{CF}-1$, at approximately $1.3 \%$ by weight of the cement, drastically decreased the amount of fluid lost under pressure. The addition of varying amounts of $\mathrm{Na}_{2} \mathrm{SO}_{4}$ or $\mathrm{Na}_{3} \mathrm{PO}_{4}$ 


$$
-50-
$$

instead of $\mathrm{CF}-1$ did not improve the slurry fluid loss characteristics. When 50 vol of of the cement was substituted with the proprietary additive pozmix, $1.3 \% \mathrm{CF}-1$ was even more effective in reducing fluid loss. The tests were made by applying 100 psi pressure to the slurry in a 3-in.-dia cylinder equipped with a 325 mesh screen. The liquid that flowed out of the cylinder was measured over a 15-min period. (Table 5.3)。

\section{Table 5.3 Fluid Loss Data with Volunteer Portland Cement, Type I}

\begin{tabular}{lcc}
\hline \multirow{2}{*}{ Additive } & \multicolumn{2}{c}{ Fluid Loss in $15 \mathrm{~min}(\mathrm{ml})$} \\
\cline { 2 - 3 } & From Waste & From Water \\
\hline None & $69 *$ & $120 * *$ \\
$\mathrm{CF}-1$ & 18 & 22 \\
$\mathrm{CF}-1+20 \% \mathrm{Na}_{3} \mathrm{PO}_{4}$ & 25 & 35 \\
$\mathrm{CF}-1+40 \% \mathrm{Na}_{3} \mathrm{PO}_{4}$ & -- & 54 \\
$\mathrm{CF}-1+20 \% \mathrm{Na}_{2} \mathrm{SO}_{4}$ & 60.5 & 40 \\
$\mathrm{CF}-1+40 \% \mathrm{Na}_{2} \mathrm{SO}_{4}$ & 24 & -- \\
$\mathrm{CF}-1+$ pozmix & 8.5 & 9 \\
\hline
\end{tabular}

*Dehydrated after 30 sec.

**Dehydrated after 40 sec.

\subsection{DISPOSAL IN NATURAI SAIT FORMATIONS}

\section{I High-Temperature Experiments (R.I. Bradshaw and F。M.Empson)}

Design of the first high-temperature experiment (High Temperature Cylinder I) related to disposal of high-level radioactive solids in holes in the floor of a salt mine and operation and results of the first test were reported previously $(4,5)$.

High Temperature Array. An array of heaters is necessary to heat a large section of the floor to a temperature above $100^{\circ} \mathrm{C}$. The minimum spacing likely to be used between cylinders of calcined waste in an actual operation is about $5 \mathrm{ft}$.

Seven heaters, $4 \mathrm{ft}$ long, spaced $5 \mathrm{ft}$ on centers in a hexagonal array (Fig. 6.I), with a power input of $3 \mathrm{kw}$ each, appear to be adequate to achieve the objectives of the test. A source of $3 \mathrm{kw}$ and 4-ft length corresponds to the case of a 6-in.-dia pot of reacidified Purex, $10 \mathrm{ft}$ long, filled once, and cooled about 1 year.

The central heater, which will simulate a calcined pot, is a 5-ft length of 6-in. schedule 40 stainless steel pipe, with $4 \mathrm{ft}$ of Cooley clamshell heaters inside. The six peripheral heaters consist of $4 \mathrm{ft}$ of furnace elements in a 2.5 -indh tabing. The central heater hole will be $10 \mathrm{in.} \mathrm{dia,} \mathrm{giving} \mathrm{a} 1.5$-in. annulus for observing possible shattering and/or flow of sait into the hole. Each of the 


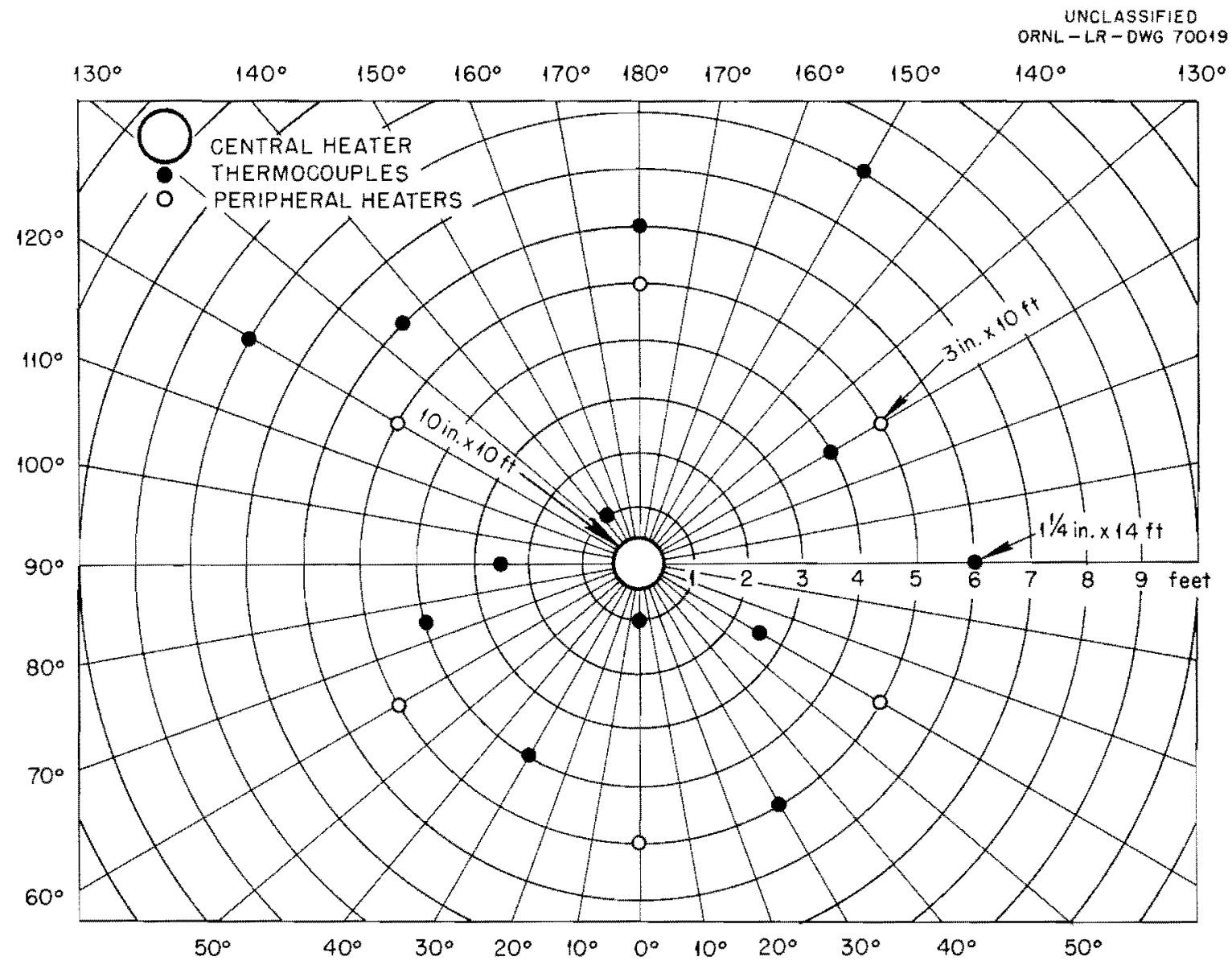

Fig. 6.1. Layout of Array - Minimum Thermocouple Requirements. 
13 thermocouple holes will have five couples located at depths of 2 , $5,8,11$, and $14 \mathrm{ft}$. (The centers of the heaters will be at a depth of $8 \mathrm{ft.)}$ Thermocouples will also be located on the outer side of the central heater pipe, as well as on the elements inside the pipe, and on one or two of the peripheral heater elements.

Because of the occurrence of water in the annulus of the first test hole, all holes in the array have been drilled dry with air as the drilling fluid. However, it now appears that the water may have come from the shale.

Since some water is expected to be released as vapor from the shale bands, a pipe heated to above $100^{\circ} \mathrm{C}$ will be inserted in the central hole annulus to a point a few inches below the top of the cylindrical heater. The upper end of this heated pipe will be connected to a condenser and be pumped at a rate of 1-5 liters $/ \mathrm{min}$ to collect the molsture, thus preventing dissolution of salt in the upper section of the hole and recrystallization in the annulus around the heater.

The top of the center hole will be stuffed with insulation bats to prevent convective heat loss to the mine air.

In order to obtain information on thermal expansion and plastic flow, three Reid-type gages and a network of approximately 25 points for precision floor leveling will be installed. Two of the gages will measure floor and ceiling movement at points close to the center of the array and close to the well and the third, colum-to-column movement. A similar array of Reid-type gages has been established about 150 ft from the center of the array for comparison. The leveling points will be scattered throughout the array and will be referenced to a point on the floor beyond the influence of the array.

Power to the heaters will be supplied from both of the Heavi-Duty power supplies used in the 7.5-ft tests. The supplies will be operated as voltage regulators with the exact power input set by means of individual variable autotransformers on each heater.

Theoretical temperature rise profiles to be expected in the plane perpendicular to the center of the heaters after 2 weeks' operation are shown in Fig. 6.2 (for comparison purposes, the profile, if only the central heaters are operated, is also shown). These were calculated from the $100^{\circ} \mathrm{C}$ thermal properties of salt, since the results of the previous test with one heater indicated conductivity and diffusivity values close to this. Since a circular area of about $14 \mathrm{ft}$ in diameter may reach temperatures above $100^{\circ} \mathrm{C}$, the effective thermal conductivity and diffusivity values in the array may be those of a higher temperature. The dashed curve was calculated from $200^{\circ} \mathrm{C}$ properties and shows the profile along the radial through a point midway between two peripheral heaters, the line of minimum temperature rise. It is expected that the actual 
UNCLASSIFIED

ORNL-LR-OWG 70020

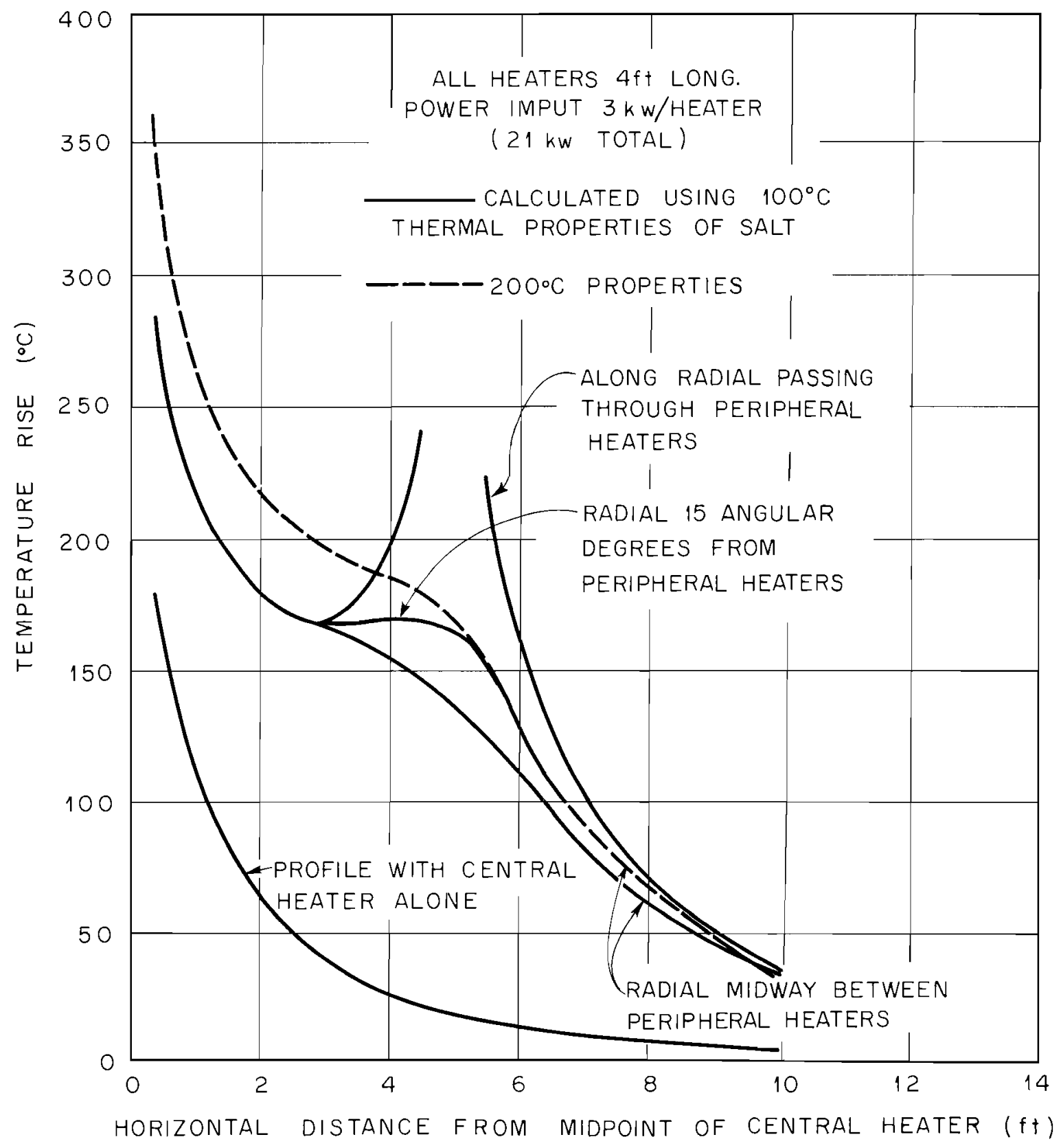

Fig. 6.2. Theoretical Temperature Rise Profiles in High-Temperature Array After Two Weeks Operation. 
profile will fall between the 100 and $200^{\circ} \mathrm{C}$ curves.

The variation in temperature rise to be expected in the vertical direction is indicated by a comparison of curves $A, D$, and $E$ in Fig. 6.3. These curves, however, are for a single heater and do not show the contributions from peripheral heaters. Curves $B$ and $C$ show the center-plane temperature rise profiles after 4 weeks and infinite times, respectively. After about 2 or 3 weeks, the vertical pattern indicated here will become distorted because of greater losses to the air than to the salt below the heaters. An equilibrium condition in the first $15 \mathrm{ft}$ of depth should be approached in 3 to 4 months.

The central heater hole will be calipered at l-ft intervals before the installation of the heater. After all heaters and thermocouples are installed, the Reid gages will be installed and the leveling points surveyed. Power will be turned on and adjusted to $3 \mathrm{kw}$ per heater.

After about half a day of operation the temperature of the periphery of the center hole should have been above $100^{\circ} \mathrm{C}$ for several hours. At this time the center hole will be inspected to see that the water vapor collection system is effective. If not the sweep air will be increased.

Temperatures in the array will be logged continuously. Reid gage readings and leveling-point measurements will be taken periodically as indicated. Additional inspections of the center hole will also be made periodically, probably daily for the first few days.

The test will be terminated after about 3 or 4 months when the temperatures and effects in the vicinity of the experiment have reached equilibrium.

High-Temperature Cylinders II and III. Two tests are planned: one in the floor and one in the wall. The heated cylinders will be duplicates of the center heater in the array. However, the power input will be increased from 3.1 to $4.5 \mathrm{kw}$ so that the peak temperature can be increased from about 200 to $300^{\circ} \mathrm{C}$. Also, instrumentation will be provided for measuring floor rise at the floor cylinder and both column expansion and floor-to-ceiling movement about the wall installation. Holes for the hightemperature cylinders are still to be drilled.

After about half a day of operation, a peak salt temperature in excess of $100^{\circ} \mathrm{C}$ should have existed for several hours. At this time the hole will be inspected to ascertain if the vapor collection system is effective. If not, sweep air will be increased.

Periodic inspection, plastic flow measurements, etc., will be made as dictated by the course of the experiment. The power input 
UNCLASSIFIED

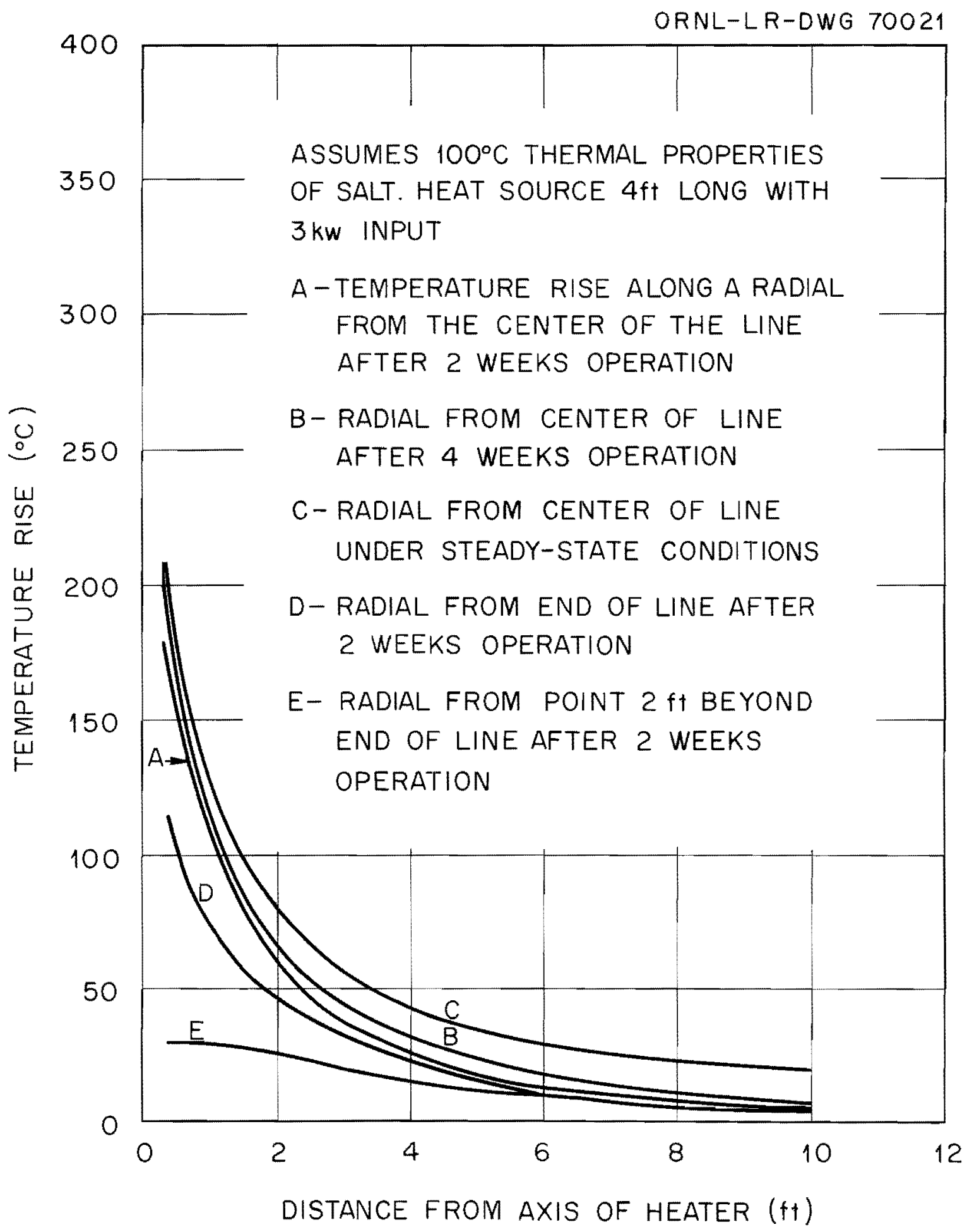

Fig. 6.3. Theoretical Temperature Rise Profiles Around a Line Heat Source. 
may be adjusted upward if the desired temperatures are not being reached.

If no shattering of salt has taken place after the temperature has been at about $300^{\circ} \mathrm{C}$ for a day or so (probably after 1 to 3 weeks), the inner diameter of the hole will be calipered at l-ft intervals to obtain information on thermal expansion and plastic flow. The experiment may then be restarted and run for 2 or 3 months or until the floor-to-celling and column-to-column movements equilibrate.

It is expected that these tests will "overlap" the array test.

6.2 Calculation of Thermal Stresses and Plastic Deformations Around Heat-Generating Cylinders Stored in Salt (W. J. Boegly, Jr., and R. E. Glover, Consultant)

The ability of salt to flow under stress will permit, when the overburden pressure is sufficiently large, the development of horizontal pressures approaching a hydrostatic state. Stress measurements in the Winnfield mine (9) at a depth of $800 \mathrm{ft}$ have shown that the stresses in the horizontal directions were substantially the same as the pressure due to the overburden. These horizontally acting pressures will remain in the floor of rooms formed by the excavation of the salt. If vertical holes are drilled in the mine floor, these stresses will be relieved at the surface of the hole; and, if the salt acts elastically, the stresses in the salt surrounding the hole can be calculated from equations

$$
\sigma_{r}=\left(1-\frac{a^{2}}{r^{2}}\right) p_{0} \quad \text { and } \quad \sigma_{\theta}=\left(1+\frac{a^{2}}{r^{2}}\right) p_{0}
$$

where

$$
\begin{aligned}
\sigma_{r} & =\text { radial stress (psi) } \\
\sigma_{\theta}= & \text { tangential stress (psi) } \\
a \quad= & \text { radius of the hole (in.) } \\
r \quad= & \text { radius of the point at which the stress is } \\
& \text { desired (in.) } \\
\mathrm{p}_{0}= & \text { overburden pressure (psi) }
\end{aligned}
$$

These equations show that at the edge of the hole where $r=a$, the tangential stress is equal to $2 p_{0}$ and the radial stress is 0 . This tangential stress ( $2 \mathrm{p}_{0}$ ) may be high enough to initiate plastic movement even before thermal stresses are produced. Due to the small fraction of the overburden pressure adjacent to the hole, the vertically acting stress, $\sigma_{z}$, will be nil and can be assumed to be 0 . 
In order to develop the equations for the plastic state, the criterion of Tresca (10) has been used. Tresca's yield criterion is that yielding will occur when the maximum shear stress reaches a certain value, $Y$, and can be expressed as

$$
\begin{gathered}
\sigma_{1}-\sigma_{3}=Y \\
\text { where } \sigma_{1} \geqq \sigma_{2} \geqq \sigma_{3} .
\end{gathered}
$$

Since the vertically acting stress, $\sigma_{z}$, is small and can be assumed $O$ for our purposes, it will be the minimum principal stress, and the maximum principal stress will be $\sigma_{\theta}$. Because of radial symmetry of shear stresses, $\tau_{r} \theta$ will be 0 . The equation of equilibrium for an element of volume is (11)

$$
r \frac{d o_{r}}{d r}+\sigma_{r}-\sigma_{\theta}=0
$$

Since $\sigma_{z}$ is assumed to be 0 , Tresca's criterion is

$$
\sigma_{\theta}-\sigma_{\mathrm{Z}}=Y
$$

or $Y=\sigma_{\theta}$

Substituting this value in eq 3 gives

$$
r \frac{d \sigma_{r}}{d r}+\sigma_{r}=Y
$$
$r=a$ is

A solution that meets the requirements that $\sigma_{r}=0$ when

$$
\sigma_{r}=Y\left(1-\frac{a}{r}\right) \quad \sigma_{\theta}=Y \quad \sigma_{z}=0
$$

It is of interest to note that this condition is completely determined by the plasticity condition, the equilibrium requirements, and the boundary condition.

The equations described above relate to a hole free of radial stress. It is also of interest to consider the effect of restraint of the inward radial displacement at $r=a$, such as would occur if the heated can were in contact with the salt walls. If the radial displacements are suppressed, $\sigma_{r}$ and $\sigma_{\theta}$ will approach the values given by

$$
\sigma_{r}=\frac{E \beta \theta}{(1-\mu)} \quad \sigma_{\theta}=\frac{E \beta \theta}{(1-\mu)} \quad \sigma_{z}=0
$$


$-58-$

where $E=$ modulus of elasticity (psi)

$\beta=$ coefficient of thermal expansion

$\theta=$ temperature rise $\left(O_{F}\right)$

$\mu=$ Poisson's ratio

When the values of $\sigma_{r}$ and $\sigma_{\theta}$ equal the yield strength of salt, all volume expansion must find relief upward as the radial flow is restrained by the can. From eq 8 , the thermal stresses in the salt surrounding the cylinder can be estimated. The upward expansion of the floor can be estimated, once the temperature rise around the cylinder and the thermal properties of salt are known, by assuming that the complete volumetric thermal expansion (three times the linear expansion) is in the vertical direction.

\subsection{Trapped Moisture in Natural Salt Formations (H. Kubota)}

Salt from the Carey Mine in Hutchinson contains inclusions of water. When the salt is heated, this water is released as steam at a temperature of about 250 to $280^{\circ} \mathrm{C}$, following a breakdown of the massive structure of the salt. Since the resultant particles vary in size from $1 / 8$ - to 1 -in. cubes, it seems very likely that the heating of pockets of water randomly distributed throughout the salt is the cause of the rupture.

A study is underway to determine the total amount of water trapped in the salt in order that the extent of heated water effects can be estimated. A device has been assembled in which salt blocks weighing 50-100 g are dissolved in refluxing methanol. The extracted water is determined by a Karl Fischer titration. Other apparatus designed to determine the total water released during the fracturing is also being assembled.

It is planned to make a survey of the trapped water in salt from various mines located throughout the country.

\subsection{Effect of Salt Extraction and Depth on Stability of Mine Openings}

(R. L. Bradshaw and W. J. Boegly)

In order to conceptually design a disposal operation in salt, It is necessary to be able to predict the allowable percentage salt extraction as a function of depth for various conditions of structural stability. Table 6.1 is a compilation of such data as is readily available on the subject. Many of the data come from the report, "Possibilities for the Storage of Radioactive Waste in Salt Cavities in the Northeastern United States," by the

Geotechnical Corporation, Dallas, Texas, February 1958. The remainder are based on personal communications and observations. 
The calculated load on the pillars is based on an assumed one pound per square inch per foot of overburden.

The mines in Table 6.1 are plotted in Fig. 6.4 as a function of calculated pillar load. Boundaries of the various conditions of stability in the figure are derived from the last column in the table. From these boundaries, the desired relations between depth of the mine, percentage salt extraction, and stability conditions were calculated (Fig. 6.5). For example, if only a negligible amount of structural flow can be tolerated, then the maximum allowable pillar load is 2000 psi, and operation to the left of curve A of Fig. 6.5 must be maintained. On the other hand, if some spalling and a slight (few per cent) closure of the rooms can be tolerated, the pillar load can be increased to 3000 psi, and operation can be anywhere to the left of curve c. In the first case (negligible flow) it may be seen from Fig. 6.5 that the stability criterion cannot be met at depths greater than $2000 \mathrm{ft}$. It may also be seen that any extraction of salt at depths greater than $3500 \mathrm{ft}$ will produce large structural flows.

The time factor involved in structural flow was not included in this study, and it may take several years for such things as roof falls and floor heaves to occur. In general, the greater the pillar load, the faster the flow. In Germany, some mines are operated with pillar loads much greater than in this country, and the rooms are either allowed to collapse or are backfilled soon after excavation to prevent collapse.

\subsection{CLINCH RIVER STUDY}

\subsection{Flow Routing (P.H. Carrigan*)}

No continuous records of flow in the Clinch River are obtained in the study reach downstream from the mouth of White Oak Creek. The nearest station at which continuous records are collected is 18 miles upstream from the mouth of the creek, at the gaging station on the Clinch near Scarboro, Tenn.

Flow in the study reach may increase rapidly four- or fivefold, during many days of the week due to power releases from Norris Reservoir. By storage and flood routing techniques the flow at the lower end of the study reach at the sampling station above Centers Ferry, near Kingston, Tenn., may be computed from the records collected at the station near Scarboro. In August 1961 the daily variations in the Clinch River flow due to power releases were observed simultaneously for $24 \mathrm{hr}$ at the gaging station near Scarboro and the sampling station above Centers Ferry. From these observations the routing equation is to be developed.

The routing equation is based on the equation of continuity for the reach.

*On loan from the Tennessee District Surface Water Branch, Water Resources Division, U. S. Geological Survey. 


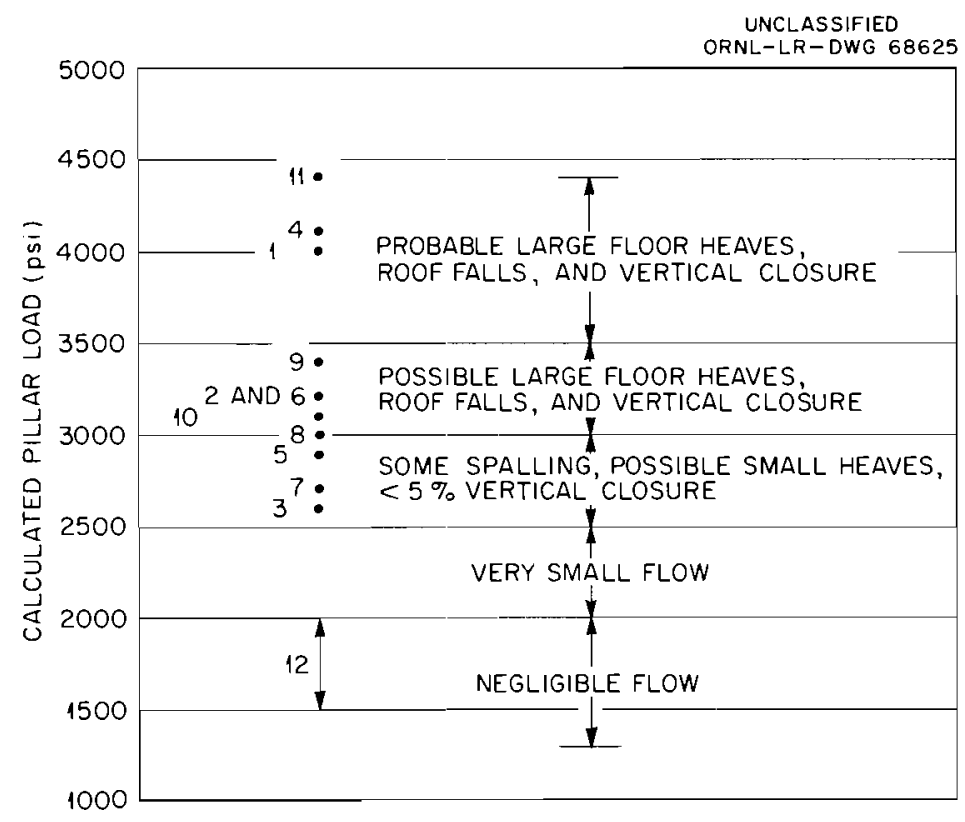

Fig. 6.4. Structural Stability in Various Salt Mines.

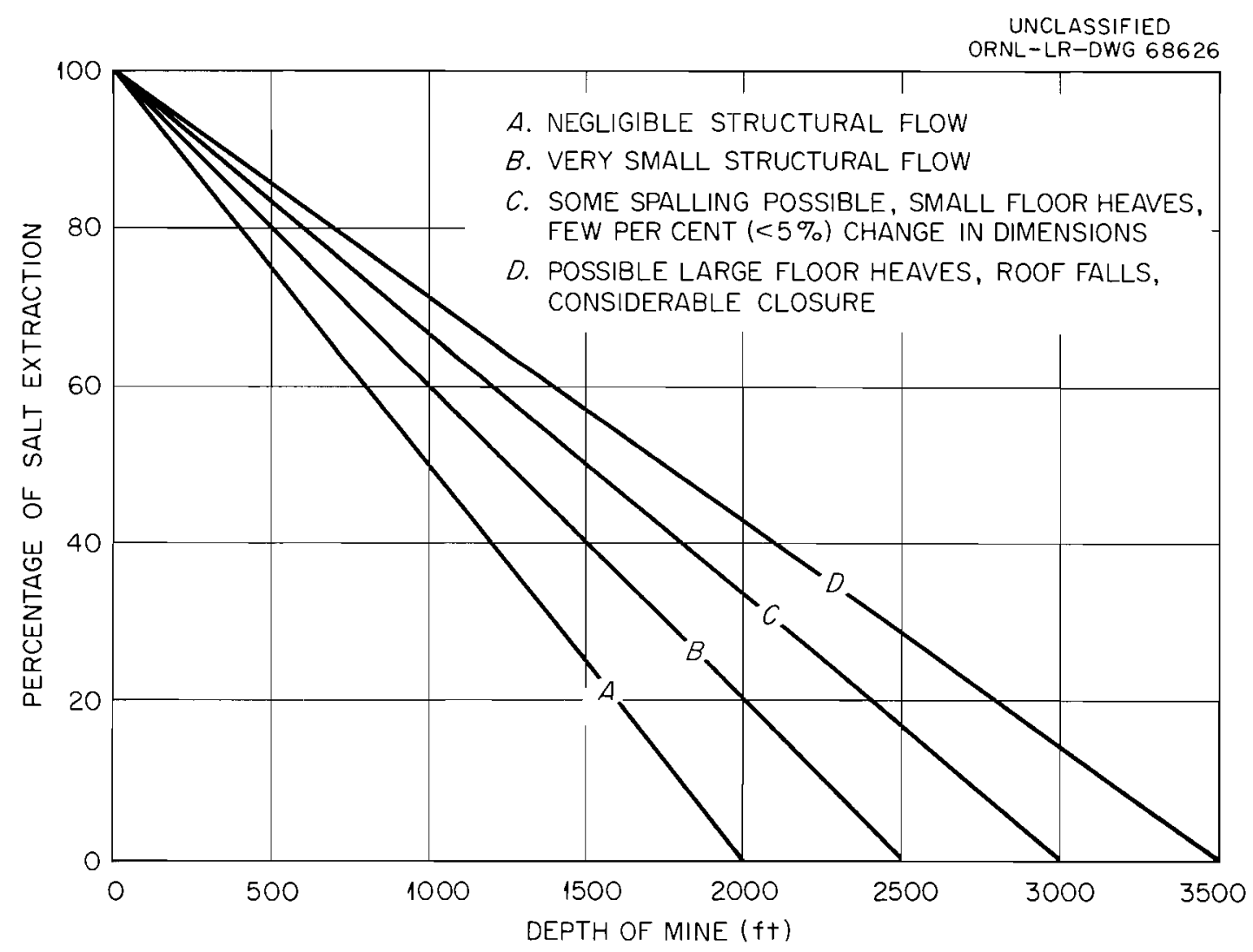

Fig. 6.5. Effect of Per Cent of Salt Extraction and Depth on Structural Stability of Mine Openings. 
Table 6.1 Salt Structural Stability Conditions in Varlous Mines

\begin{tabular}{|c|c|c|c|c|c|c|c|}
\hline & Mine & Location & $\begin{array}{l}\text { Depth } \\
(\mathrm{ft})\end{array}$ & $\begin{array}{l}\text { Per Cent } \\
\text { Extraction }\end{array}$ & $\begin{array}{l}\text { Room } \\
\text { Height } \\
\text { (ft) }\end{array}$ & $\begin{array}{l}\text { Calculated } \\
\text { Pillar Load } \\
\text { (psi) }\end{array}$ & Structural Conditions \\
\hline 1. & American & Lyons, Kan. & 990 & 75 & 9 & 4000 & Flow reported \\
\hline 2. & Carey & Futchinson, Kan. & 645 & 80 & $6-12$ & 3200 & $\begin{array}{l}\text { Early mining; stable but some } \\
\text { spalling }\end{array}$ \\
\hline 3. & Carey & Hutchins on, Kan. & 645 & 75 & 12 & 2600 & $\begin{array}{l}\text { Current mining; less spalling; } \\
\sim 0.5 \% \text { vertical closure }\end{array}$ \\
\hline 4. & Carey & Lyons, Kan. & 1020 & 75 & $9-14$ & 4100 & $\begin{array}{l}\text { Early mining; large floor } \\
\text { heaves and roof falls from } \\
\text { shale partings }\end{array}$ \\
\hline 5. & Carey & Lyons, Kan. & 1020 & 65 & $9-14$ & 2900 & $\begin{array}{l}\sim 1940 \text {; small floor heaves } \\
\text { above shale parting }\end{array}$ \\
\hline 6. & Carey & Winfield, La. & 970 & 70 & & 3200 & Some flow reported \\
\hline 7. & Carey & Winfield, La. & 970 & 64 & & 2700 & No trouble reported \\
\hline 8. & $\begin{array}{l}\text { Grand } \\
\text { Saline }\end{array}$ & Grand Saline, Tex. & 700 & est. 77 & & 3000 & Vertical closure $4 \%$ \\
\hline 9. & Independent & Kanopolis, Kan. & 840 & 75 & $8-9$ & 3400 & $\begin{array}{l}\text { Large floor heaves and roof } \\
\text { falls from shale parting }\end{array}$ \\
\hline 10. & $\begin{array}{l}\text { Inter- } \\
\text { national }\end{array}$ & Detroit, Mich. & 1100 & 65 & & 3100 & $\begin{array}{l}\text { Generally good; only one small } \\
\text { roof fall }\end{array}$ \\
\hline 1. & Retsof No.I & Retsof, $\mathbb{N} . Y$ & 1100 & 75 & & 4400 & $\begin{array}{l}\text { 1920; large floor heaves, roof } \\
\text { falls, and heavy spalling }\end{array}$ \\
\hline 12. & Retsof No. & 1 Retsof, N.Y. & 1050 & $30-47$ & & $1500-2000$ & $\begin{array}{l}\text { Current mining; no spalling or } \\
\text { heaving }\end{array}$ \\
\hline
\end{tabular}




$$
\frac{O_{1}+o_{2}}{2}=\frac{I_{1}+I_{2}}{2}-\frac{\left(S_{2}-S_{1}\right)}{\Delta t}
$$

in which the average outflow is $\left(O_{1}+O_{2}\right) / 2$, the average inflow is $\left(I_{1}+I_{2}\right) / 2$, and the change in storage is $S_{2}-S_{1}$ during some short time interval $\Delta t$. The outflow was measured at the station above Centers Ferry by the U.S. Geological Survey. The inflow was determined from USGS discharge records collected at the station near Scarboro.

The rate of change of storage, $\left(s_{2}-s_{1}\right) / \Delta t$, is the rate of change of the volume of water stored in the channel and may be thought of as the product of the water surface area and the rate of rise, or fall, of the water surface. This storage may be expressed as function of the weighted mean flow through the reach (12):

$$
S=K\lceil X I+(I-X) 0\rceil
$$

in which $S, I$, and $O$ are the storage, inflow, and outflow; $K$ is the slope of the relation; and $X$ is a factor that weights the inflow and outflow. If this relation is substituted into the continuity equation, the resulting expression is of the type

$$
\mathrm{O}_{2}=\mathrm{Co}_{2}+\mathrm{C}_{1} \mathrm{I}_{1}+\mathrm{C}_{2} \mathrm{O}_{1}
$$

in which $\mathrm{Co}, \mathrm{C}_{1}$, and $\mathrm{C}_{2}$ are functions of $\mathrm{K}, \mathrm{X}$, and $\Delta \mathrm{t}, \mathrm{By}$ graphical means, outlined by Carter and Godfrey (12), the value of $K$ was found to be $6.6 \mathrm{hr}$ and the value of $\mathrm{X}, 0.5$ for a routing period $\Delta t$, of $1 \mathrm{hr}$. The resultant routing equation is

$$
\mathrm{O}_{2}=-0.737 \mathrm{I}_{2}+\mathrm{I}_{1}+0.7370_{1}
$$

Only slight attenuation of the power waves were observed during the period of study. Such waves are described as uniformly progressive flows (12). For this type of flow the theoretical value of $\mathrm{X}$ is 0.5 .

The procedure of computation is a numerical step method. The flow in the Clinch River above Centers Ferry, $\mathrm{O}_{2}$, at the end of the 1-hr routing period is determined from the outflow at the beginning of the period, $O_{1}$, and the inflows, $I_{1}$ and $I_{2}$, at the beginning and end of this same period, observed at the station on the Clinch near Scarboro. Each value of $\mathrm{O}_{2}$ obtained is the value of $\mathrm{O}_{1}$ used in successive computations.

The routing equation has been determined for the period in which tributary inflow to the Clinch downstream from the gaging station near scarboro is reasonably steady and fairly low (as indicated by records of discharge for White Oak Creek at White Oak Dam, near Oak Ridge). The procedure for routing power 
releases may have to be modified for periods affected by storm runoff from tributary areas and by low levels in Watts Bar Reservoir.

\subsection{Effect of Geology on Quality of Water of Clinch River Tributaries}

$$
\text { (R. J. Pickering*) }
$$

Stable-chemical analyses of water samples taken during base flow measurements in September 1961 show marked differences in the quality of water between streams draining coal-bearing clastic rocks of the Cumberland escarpment and streams draining predominantly carbonate rocks of the ridge and valley province in which Oak Ridge National Laboratory is located. Drainage areas of Popular Creek above Batley Road near Oliver Springs, Tenn., and Indian Creek above Oliver Springs are underlain by a coal-bearing sequence of sandstone and shale, while BulIrun Creek near Clinton, Tenn, and Scarboro Creek south of Oak Ridge, Tenn., drain areas underlain by dolomite, limestone, and shale.

The two streams draining clastic rocks of the Cumberland escarpment are distinguished from the streams draining predominantIy carbonate rocks by their higher content of sulfate, sodium, and chloride and their somewhat lower pH. The higher sulfate content is probably the result of oxidation of iron sulfides in the coal and shale. This process and the precipitation of dissolved iron as a hydroxide in aerated water account for the lower $\mathrm{pH}$ of Indian and Poplar Creeks. Silica is highest in the acid water of Indian Creek. Figure 7.I illustrates the two types of water. Poplar Creek above Batley Road receives some drainage from areas underlain by carbonate rocks and thus might be considered intermediate between Indian Creek and Bullrun and Scarboro Creeks in regard to the geology of its drainage area.

\subsection{FUNDAMENTAI, STUDTES OF MINERAIS}

\subsection{Behavior of Cesium in Vermiculite Systems (D. G. Jacobs)}

The behavior of cesium in vermiculite systems is of interest for two reasons: (I) vermiculite is one of the few clay minerals with a sufficiently large particle size to be of practical use in waste decontamination by columns, and (2) when it is treated with one of the heavier alkalai metal cations, the lattice spacing changes measurably, producing steric effects which alter the exchange properties of the vermiculite. Thus the study of the exchange properties of vermiculite permit a simultaneous study for improving decontamination of cesium-bearing waste streams and for depicting the possible exchange reactions of cesium in the ground.

Ion exchange by clay minerals follows the same general laws as ion exchange by synthetic resins, although a few notable differences must be considered. The exchange complex of a clay *On loan from the Tennessee District Surface Water Branch, Water Resources Division, U. S. Geological Survey. 


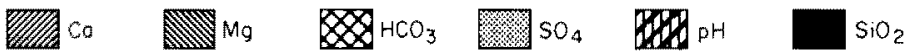

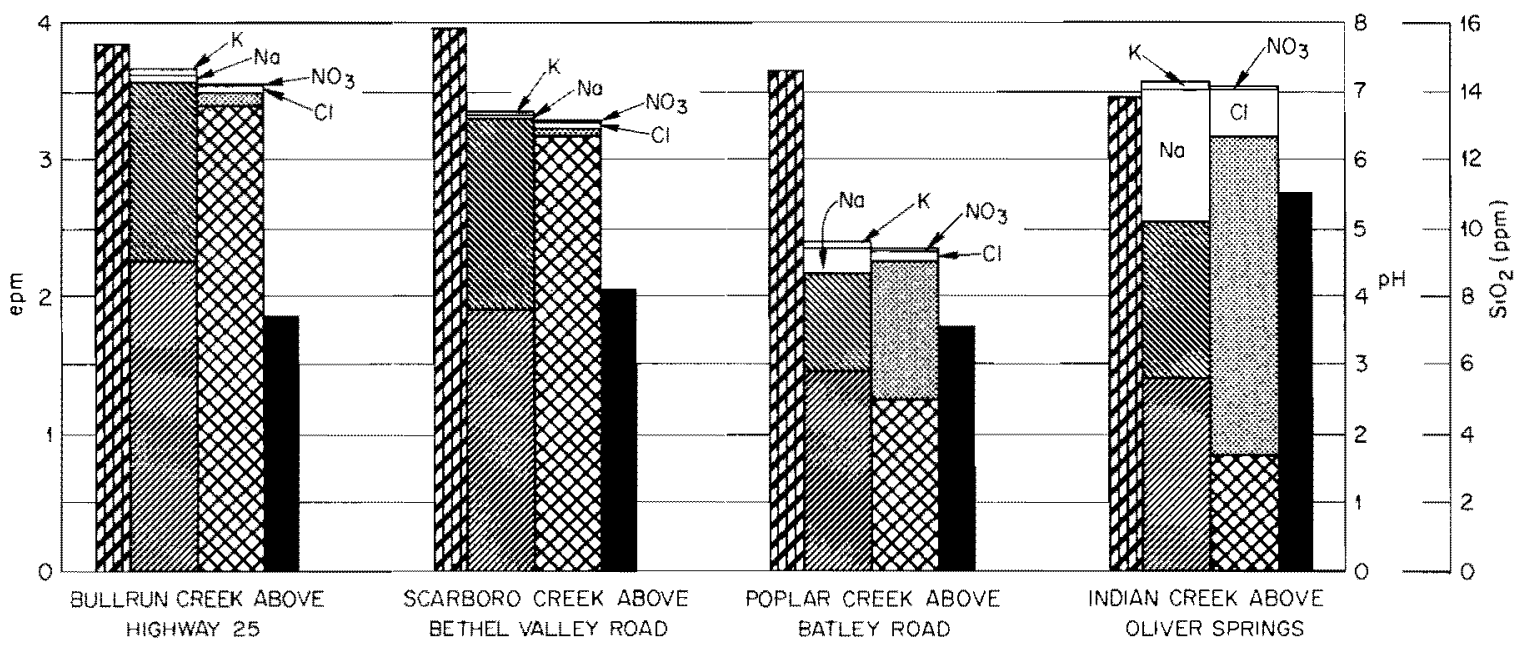

Fig. 7.1. Base Flow Analyses, September 1961. 
mineral is not homogeneous, but the exchange sites differ depending on the origin of the charge deficiency. In most cases the counterions, those of opposite sign of charge from the exchanger material, cannot penetrate the clay mineral lattice to neutralize the resident charge. Thus, an electric double layer is established at the exterior of the clay mineral lattice and the atomic structure of the rigid surface of the clay mineral often limits the nearness of approach of the counterions to seats of charge residing within the crystal

lattice. In many of the clay minerals, notably the 2:1 layer lattice minerals having a $10 \AA \mathrm{c}$-spacing (collapsed lattice minerals), a substantial fraction of the lattice charge deficiency resides along the surface between the successive layer lattices (within the basal spacing), and migration of counterions to and from these sites is impeded because the opening between the layers is small compared to the size of the counterions. Furthermore, the basal spacing terminates in incomplete hexagonal networks of oxygen atoms, providing a void of nearly ideal dimensions for the accommodation of the heavier alkalai metal cations. When cesium, rubidium, potassium, or ammonium ions are introduced into such an exchange system they are strongly held at lattice edges by such exchange sites, migration along the basal spacing being a very slow process. Because this type of exchange site constitutes only a small fraction of the total exchange sites available, the selectivity for sorption of the heavier alkalai metal cations compared to sodium increases markedly with decreasing concentrations in a system of fixed sodium concentration. This phenomenon has been referred to as "edge fixation," to differentiate it from the less selective exchange processes occurring at exchange sites having a lower degree of steric favorability.

In the case of vermiculite, successive lattices are separated by a sufficient distance to allow rather free migration of counterions through the basal spacing. However, if vermiculite is treated with potassium the dehydrated potassium ion partially penetrates the open hexagonal network of oxygen atoms composing the basal surface, and its close approach to the seat of charge of the mineral lattice causes neutralization of the charge, reducing the repelling forces holding the lattice sheets apart and allowing them to collapse. The potassium occupying these basal exchange sites is now held strongly by "interlayer fixation" as a result of close approach of the counterion to the seat of charge coupled with steric impedance of the outward movement of the potassium ions from the basal spacing.

Pretreatment of Vermiculite with Potassium. Vermiculite (hydrobiotite obtained from the Zonolite Co., Traveler's Rest, S.C.) was pretreated with potassium to give varying degrees of collapse of the interlayered biotite-vermiculite lattices. Lattice collapse was accompanied by a drop in the exchange capacity because the exchange sites lying within the collapsed basal spacing are no longer freely accessible to the ccunterions (Table 8.1). Seven and a half liters of $0.5 \mathrm{M} \mathrm{NaNO}_{3}$ containing the mass equivalent of $2 \mu \mathrm{c}$ of $\mathrm{Cs}-137$ per milililiter and tagged with $\mathrm{Cs}-137$ was passed through $10-8$ columns of the vermiculite at an average flow rate of 
$1.3 \mathrm{ml} \mathrm{cm} \mathrm{cm}^{-2} \mathrm{~min}^{-1}$. After the columns were saturated with cesium, they were divided into four sections for determination of the final exchange capacity, by the calcium titration method of Jackson (13), and the cesium loading. Each solution used in determination of the exchange capacity was counted for cesium and the total cesium leached by five treatments with $100 \mathrm{ml}$ of $1 \mathrm{M} \mathrm{CaCl}$, three treatments with $100 \mathrm{ml}$ of distilled water, three treatments with $100 \mathrm{ml}$ of $95 \%$ ethanol, and five treatments with $100 \mathrm{ml}$ of sodium acetate was computed. The $\mathrm{K}_{\mathrm{d}}$ for cesium increased with a decrease in exchange capacity because of the increased number of edge fixation sites make available by lattice collapse. The leaching action of the sodium nitrate removed of the potassium from interlayer fixation sites, causing expansion of part of the vermiculite lattices. This was most apparent in columns 5 and 6 where the top of the colum was subjected to more vigorous leaching, resulting in a higher final exchange capacity and lower cesium $K_{d}$ from top to bottom in the column.

The decreased leaching of cesium from columns more nearly saturated can be accounted for by the increased number of edge fixation sites or by the cesium $\mathrm{K}_{\mathrm{d}}$. The sorption mechanism apparently remains the same for all columns.

Table 8.1 Effect of Potassium Treatment of Vermiculite on Cesium Sorption from $0.5 \mathrm{M}$ NaNO3 Containing the Mass Equivalent of $2 \mu \mathrm{c}$ of Cs-137 per milliliter

\begin{tabular}{|c|c|c|c|c|c|}
\hline $\begin{array}{l}\text { Column } \\
\text { No. }\end{array}$ & $\begin{array}{l}\text { Initial CBC } \\
(\mathrm{meq} / 100 \mathrm{~g})\end{array}$ & $\begin{array}{l}\text { Final CEC } \\
\text { (meq/loog) }\end{array}$ & $\underset{(\mathrm{ml} / \mathrm{g})}{\operatorname{Cesium}} K_{\mathrm{d}}$ & $\begin{array}{c}\text { Cesium Leached } \\
(\%)\end{array}$ & $\begin{array}{l}\text { X-ray Diffraction } \\
\text { (before saturation) }\end{array}$ \\
\hline 1 & 55.7 & 74.9 & 108 & 16.3 & $\begin{array}{l}\text { No change from } \mathrm{Na} \\
\text { vermiculite }\end{array}$ \\
\hline 2 & 48.9 & 73.9 & 112 & 15.1 & $\begin{array}{l}\text { Random interlayer- } \\
\text { ing with lower } \\
\text { spacings }\end{array}$ \\
\hline 3 & 42.3 & 75.0 & 124 & 14.4 & $\begin{array}{l}\text { Equa.11y intense } \\
\text { maxima at } 10 \AA \\
\text { and } 11 \AA .\end{array}$ \\
\hline 4 & 38.0 & 73.7 & 133 & 16.1 & $\begin{array}{l}\text { Most intense maximum } \\
\text { at } 10 \AA \text {; } \text {, lso peak } \\
\text { at } 11 \AA\end{array}$ \\
\hline 5 & 13.0 & 64.2 & 201 & 9.0 & $\begin{array}{l}10 \AA \text { peak with } \\
\text { random inter- } \\
\text { layering of higher } \\
\text { spacings }\end{array}$ \\
\hline 6 & 5.9 & 45.9 & 272 & 7.0 & Sharp $10 \AA$ peak \\
\hline
\end{tabular}

Addition of Potassium to the Influent. When potassium is added to the $0.5 \mathrm{M} \mathrm{NaNO}_{3}$ influent solution it is possible to get 


$$
.67-
$$

simultaneous sorption of cesium and potassium. If the potassium concentration is too low to initiate lattice collapse, the potassium competes with cesium for the edge fixation sites (Table 8.2).

$$
\begin{aligned}
\text { Table } 8.2 \frac{\text { Effect of Addition of Potassium to the Influent }}{\text { on the Sorption of Cesium by Vermiculite from }} \\
\frac{0.5 \mathrm{M} \mathrm{NaNO} 3 \text { Containing the Mass Equivalent } 2 \mu \mathrm{c}}{\text { of Cs }-137 \text { per milliliter }}
\end{aligned}
$$

\begin{tabular}{|c|c|c|c|c|}
\hline $\begin{array}{l}\text { Potassium } \\
\text { Conc. } \\
(\underline{M})\end{array}$ & $\begin{array}{l}\text { Cesium } \mathrm{K}_{\mathrm{d}} \\
(\mathrm{ml} / \mathrm{g})\end{array}$ & $\begin{array}{c}\text { Cesium Leached } \\
(\%)\end{array}$ & $\begin{array}{l}\text { Final CEC } \\
\text { (meq/100g) }\end{array}$ & $\begin{array}{l}\text { X-Ray Diffraction } \\
\text { (after Saturation) }\end{array}$ \\
\hline 0.0000 & 154 & 12.6 & 75.4 & \\
\hline 0.0001 & 147 & 13.0 & 74.9 & \\
\hline 0.001 & 137 & 15.2 & 70.2 & \\
\hline 0.01 & 357 & 7.60 & 60.0 & \\
\hline 0.02 & 483 & 5.33 & 38.1 & $\begin{array}{l}\text { First signs of } \\
\text { increased inter- } \\
\text { layering with } \\
\text { lower spacings }\end{array}$ \\
\hline 0.03 & 695 & 4.90 & 26.2 & $\begin{array}{l}10 \AA \text { peak with some } \\
\text { random interlayer- } \\
\text { ing with higher } \\
\text { spacings }\end{array}$ \\
\hline 0.04 & 727 & 4.63 & 17.9 & \\
\hline 0.05 & 634 & 4.56 & 15.3 & \\
\hline 0.08 & 373 & 4.10 & 9.1 & Sharp $10 \AA$ peak \\
\hline 0.10 & 265 & 3.26 & 8.6 & \\
\hline
\end{tabular}

As the potassium concentration is increased, lattice collapse occurs and the cesium and potassium are entrapped by "interlayer fixation," as evidenced by a drop in the exchange capacity and a decrease in the percentage of cesium leached. Although the potassium is competitive with cesium for the interlayer fixation sites, the cesium $\mathrm{K}_{\mathrm{d}}$ increases with increasing potassium concentration, passing through a maximum at $0.04 \mathrm{M} \mathrm{KNO}_{3}$. Above this concentration the increased potassium concentration is not balanced by an increase in the number of interlayer fixation sites.

The percentage of the cesium leached is more directly related to the exchange capacity than to the cesium $K_{d}$, decreasing as the exchange capacity decreases. This is due to a shift from edge fixation to interlayer fixation as the dominant sorption mechanism. As a greater fraction of the cesium occupies interlayer fixation sites, it is less readily leached. 
Addition of Other Collapse-inducing Cations to the Influent. other heavy alkalai metal cations and ammonium ions also cause collapse of the vermiculite lattice. Since they are more strongly held than potassium, a smaller concentration is required in.0.5 M $\mathrm{NaNO}_{3}$ to initiate lattice collapse and to obtain optimum cesium removals (Table 8.3). The behavior of the ammonium-treated influent

Table 8.3 Optimum Concentrations of Collapse-inducing Cations for Cesium Sorption by Vermiculite from $0.5 \mathrm{M} \mathrm{NaNO} 3$ Containing the Mass Equivalent of $2 \mu \mathrm{c}$ of $\mathrm{Cs}-137$ per milliliter

\begin{tabular}{lcccc}
\hline Cation & $\begin{array}{l}\text { Cation } \\
\text { Conc } \\
(\mathrm{M})\end{array}$ & $\begin{array}{c}\text { Cesium } \\
(\mathrm{ml} / \mathrm{g})\end{array}$ & $\begin{array}{c}\text { Cesium } \\
\text { Leached } \\
(\%)\end{array}$ & $\begin{array}{c}\text { Final CEC } \\
(\mathrm{meq} / 100 \mathrm{~g})\end{array}$ \\
\hline $\mathrm{K}^{+}$ & & & & \\
$\mathrm{NH}_{4^{+}}{ }^{+}$ & 0.040 & 727 & 4.63 & 17.9 \\
$\mathrm{Rb}^{+}$ & 0.010 & 1851 & 13.1 & 42.8 \\
$\mathrm{Cs}^{+}$ & 0.0015 & 556 & 4.22 & 41.0 \\
& 0.0004 & 557 & 3.38 & 47.7 \\
\hline
\end{tabular}

was somewhat different from that of the other systems; the $K_{\mathrm{d}}$ was higher but the percentage of cesium leached was also much greater than for the alkalai metal cations.

Step Increases in Influent Potassium Concentration. Because collapse of all interlayer spacings does not occur at the minimal corcentration for initiating lattice collapse and because increases in the potassium concentration increase competition with cesium for fixation sites, it seemed that the optimum procedure would be to operate at the minimum $\left(\mathrm{K}^{+}\right) /\left(\mathrm{Na}^{+}\right)$until the easily collapsed lattices are all in the collapsed state. This would be evident by an increase in the cesium activity of the effluent. Gradual increases of the $\left(\mathrm{K}^{+}\right) /\left(\mathrm{Na}^{+}\right)$would result in additional lattice collapse and increased cesium sorption, until finally a state would be reached where all possible collapse had been accomplished. Beyond this point, increases in potassium concentration would merely interfere with cesium sorption.

Two liters of the $0.5 \mathrm{M} \mathrm{NaNO}_{3}$ solution was passed through a 10-g vermiculite column. Complete cesium breakthrough was observed. When the influent solution was brought to $0.01 \mathrm{M}$ with respect to $\mathrm{KNO}_{3}$, the cesium activity of the effluent dropped to less than $15 \%$ of the influent activity after $200 \mathrm{ml}$ solution had passed through the column. A second breakthrough wave was observed when 2 liters of this solution had passed through the column, and cesium activity in the effluent was decreased to less than $1 \%$ of the influent activity by increasing the potassium concentration of the influent to $0.02 \mathrm{M}$. A third 
$-69-$

breakthrough wave occurred after passage of 2 liters of this solution. This was followed by 7.5 liters of $0.03 \mathrm{M} \mathrm{KNO}_{3}, 2.6$ liters of $0.05 \mathrm{M}$, 1.25 liters of $0.08 \mathrm{M}$, and 0.35 liters of $0.10 \mathrm{M} \mathrm{KNO}_{3}$. After this last breakthrough wave, 0.25 liter of the $0.5 \mathrm{M} \mathrm{NaNO}_{3}$ solution was passed through the column before the final breakthrough wave was obtained. A cesium $\mathrm{K}_{\mathrm{d}}$ of $2255 \mathrm{ml} / \mathrm{g}$ was obtained, $4.49 \%$ of which was leached off during the determination of the exchange capacity. The final exchange capacity of the vermiculite was $18.3 \mathrm{meq} / 100 \mathrm{~g}$.

\subsection{WHITE OAK CREEK BASIN STUDY*}

\subsection{Sources of White Oak Creek Contamination (T. F. Lomenick)}

The PWWTP is the major source of contamination to White Oak Creek within Bethel Valley (ORN plant site). However, significant quantities of radionuclides enter the creek from other facilities in the valley. Temporary water sampling stations were installed along White Oak Creek at miles 2.6 and 3.9 and the tributary stream draining the northwest portion of the Bethel Valley area to assess the amount and type of activity associated with fallout, burial grounds, and other sources that could not be monitored directly (see Fig. 9.1). In addition, representative samples were taken of the effluent from the laundry and the sewage treatment plant. The sampling devices used at the stations have been described previously (14). A summary of the activity detected at the laundry, sewage treatment plant, stream sampling stations, and the PWWTP for the period May-Oct. 1961 is shown in Table 9.1.

It is of interest to note that, during the 6-month sampling period, the sewage treatment plant contributed approximately $150 \mathrm{mc}$ of Sr-90, $100 \mathrm{mc}$ of TRE $3+,{ }^{*} 32 \mathrm{mc}$ of $\mathrm{Cs}-137,7 \mathrm{mc}$ of $\mathrm{Co}-60$, and $7 \mathrm{mc}$ of Ru-106. Although the amount detected is small in comparison to that released from the PWWTP, it is rather large for a facility that should be relatively free from contamination. The mean concentration of $\mathrm{Sr}-90$ in the sewage water effluent was $1.7 \times 10^{-6} \mathrm{\mu c} / \mathrm{cc}$ or about $40 \%$ of the $\mathrm{MPC}_{\mathrm{w}}$. The weekly contribution of Sr-90 to the creek from this facility was fairly constant, but for the remaining radionuclides the releaes were somewhat sporadic.

The amounts of activity detected in weekly samples at the stream stations vary over a wide range. (14) An apparent relation between stream discharge and strontium transport was shown, and an increase in the suspended solid load in the stream was generally followed by a corresponding increase in cesium transport (Fiğ. 9.2). Thus, during

*This project, entitled "Environmental Radiation Studies: Evaluation of Fission Product Distribution and Movement in White Oak Creek Drainage Basin," (AEC Activity No.060501000) is supported by the U.S. Atomic Energy Commission's Division of Biology and Medicine. All other projests covered in this Bimonthly Progress Report are supported by the Division of Reactor Development (AEC Activity No.04640011).

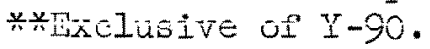


Table 9.1 Radionuclides Discharged to White Oak Creek from Sources in Bethel Valley May-October 1961

\begin{tabular}{|c|c|c|c|c|c|c|c|c|c|c|}
\hline \multirow{2}{*}{ Station } & \multicolumn{2}{|c|}{$\mathrm{Sr}-89 \& 90$} & \multicolumn{2}{|c|}{ TRE* } & \multicolumn{2}{|c|}{$\mathrm{Cs}-137$} & \multicolumn{2}{|c|}{$\mathrm{Co}-60$} & \multicolumn{2}{|c|}{ Ru-106 } \\
\hline & $(\mathrm{mc})$ & (\%) & (mc) & $(\%)$ & $(m c)$ & $(\%)$ & (mc) & (\%) & $(m c)$ & $(\%)$ \\
\hline Northwest tributary stream & 33 & 0.85 & 34 & 1.38 & 30 & 2.98 & 1 & 0.23 & 7 & 1.98 \\
\hline White Oak Creek Mile 2.6 & 123 & 3.17 & 83 & 3.28 & 153 & 15.21 & 89 & 20.41 & 43 & 12.15 \\
\hline Sanitary sewage & 150 & 3.87 & 100 & 3.95 & 32 & 3.18 & 7 & 1.61 & 7 & 1.98 \\
\hline Laundry & 9 & 0.24 & 11 & 0.44 & 11 & 1.09 & 6 & 1.37 & 1 & 0.28 \\
\hline $\begin{array}{l}\text { Process waste water treat } \\
\text { ment plant }\end{array}$ & 3560 & 91.87 & 2300 & 90.95 & 780 & $77 \cdot 54$ & 333 & 76.38 & 296 & 83.61 \\
\hline Totals & 3875 & 100.00 & 2528 & 100.00 & 1006 & 100.00 & 436 & 100.00 & 354 & 100.00 \\
\hline
\end{tabular}

*Excluding $\mathrm{Y}-90$. 


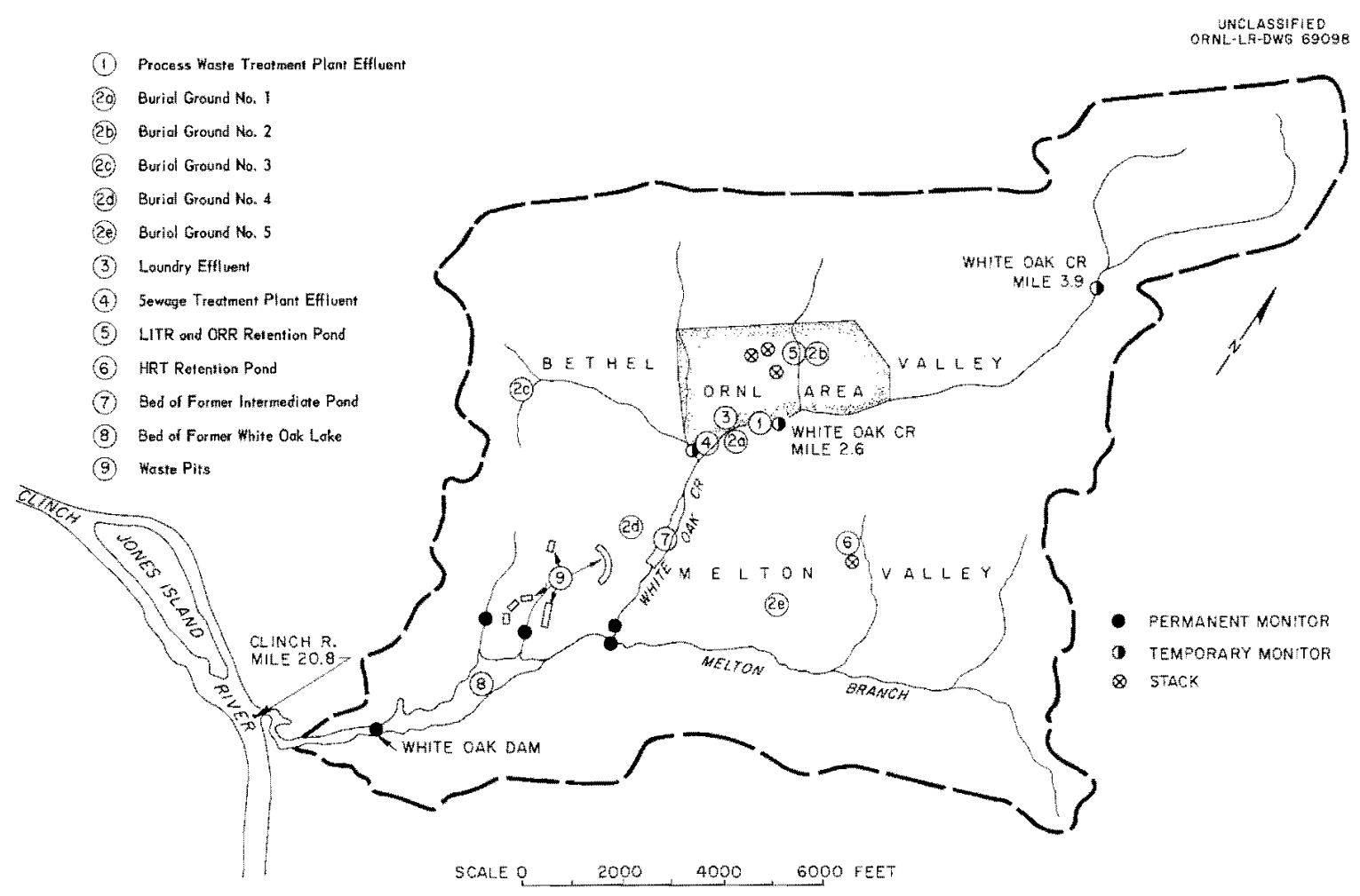

Fig. 9.1. Map of White Oak Creek Basin Showing Sources of Radioactive Contamination and Stream - Monitoring Stations. 

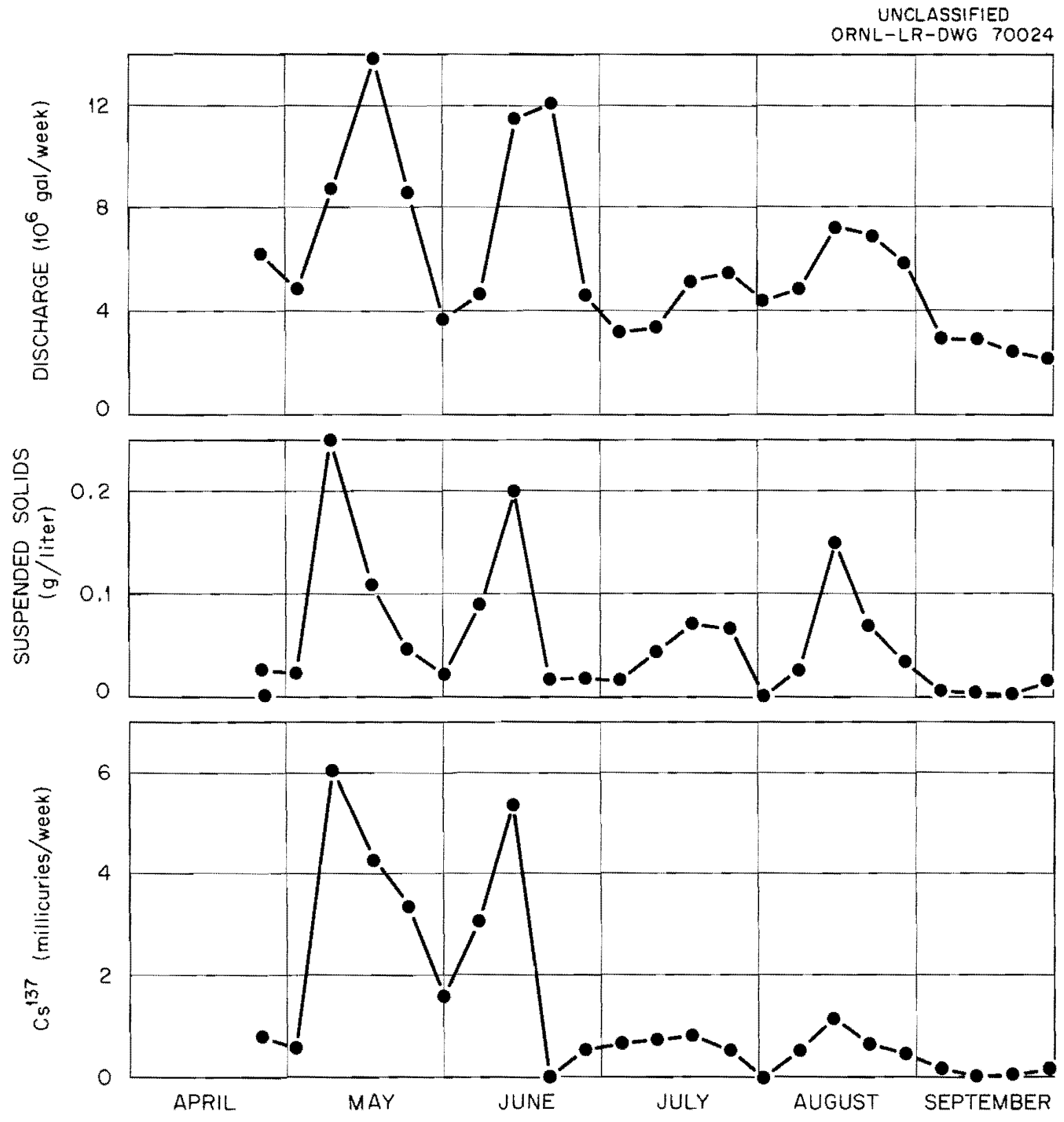

Fig. 9.2. Stream Discharge, Suspended Solids and Cs-137 Transport at Northwest Tributary Station. 


$$
-73-
$$

periods of high stream discharge and/or a heavy suspended solid load, the transport of strontium and/or cesium is usually high. The cesium transport in weeks in which suspended-solid loads were high exceeded that in several weekly periods when the suspended solid concentration was low. This condition indicates that during most periods the transport of radionuclides past the stream sampling stations is relatively small compared to that discharged to the creek from the PWWTP, but in short times substantial amounts are transported.

\subsection{Hyarology of White Oak Creek Basin (W.M. McMasters*)}

Large-scale aerial photographs of the White Oak Creek basin, made in March 1959 for the Ecology Section of Health Physics Division, were obtained for use in mapping the geology of the basin. Geologic mapping began on April 2 in the northwestern part of the basin.

Invitations to bid on a 500-to 600-ft-deep churn-drill well were issued during the week of April 8. The well is to be located on Melton Hill and will begin in the Knox dolomite and finish in Conasauga shale.

A staff gage was installed on a spring-fed tributary to White Dak Creek at a point south o: Bethel Valley Road and north of the cooling tower at Bldg. 3103. The gage is being rated by discharge measurements made at different stages. The tributary receives a substantial amount of plant discharge between this point and its confluence with White Oak Creek. A second gaging station is planned for installation on the tributary near its mouth as a means of approximating plant discharge to the tributary during base flow measurements.

*On loan from the Water Resources Ilivision, Surface Water Branch, U.S. Geological Survey. 
10.0 REFERENCES

1. "Waste Treatment and Disposal Progress Report for April and May 1961," ORNL-CF-6I-7-3.

2. J. M. Morgan, Jr., D. K. Jamison, J. D. Stevenson, "Fixation of Radioactivity in Stable Solid. Media, Report on the Second Working Meeting at Idaho Falls, Idaho," Sept. 27-29, 1960, TID-7613, Books 1 and 2 .

3. R. M. Beckers, "Design Report Calciner Pot for Liquid Waste Calcination Program," ORNL-CF-62-4-20 (1962).

4. "Waste Treatment and Disposal Progress Report for October and November 1961," ORNL-TM-133, Sect. 4.0.

5. "Waste Treatment and Disposal Progress Report for December 1961 and January 1962," ORNL-TM-169, Sect. 4.0.

6. J. T. Roberts and R. R. Holcomb, "A Phenolic Resin Ion-Exchange Process for Decontaminating Low-Radioactivity-Level Process Water Wastes," ORNL-3036 (May 22, 1961). Ibid., "Low-level Waste Treatment by Ion Exchange. II. Use of a Weak Acid CarboxylicPhenolic Ion-Exchange Resin," ORNL-TM-5 (Sept. 25, 1961). Ibid., "The Phenolic Resin Ion Exchange Process for Decontaminating Low-Activity-Level Process Water Wastes," ORNL-CF-60-8-103, (Aug. 1960).

7. J.S. Watson, "Unit Operations Section Monthly Progress Report," ORNL-TM-34, June 1961, p. 32。

8. "API Recommended Practice for Testing Oil Well Cements and Cement Additives, "API Research Paper 1OB, March, 1961.

9. R.H. Merrill, "Static Stress Determinations in Salt-Site Cowboy," U.S. Bur. Mines Rept., APRL 38-3.1. (July 29, 1960).

10. R. Hill, "The Mathematical Theory of Plasticity," Oxford Univ. Press, London, 1956, p. 19.

11. S. Timoshenko and J.N. Goodier, "Theory of Elasticity," MeGraw-Hil1, New York, 1951, p. 406.

12. R. W. Carter and R. G. Godfrey, "Storage and Flood Routing," U. S. Geological Survey Water Supply Paper 1543-B (1960).

13. M. I. Jackson, "Soil Chemical Analysis," Prentice-Hall, Inc., Engelwood Cliffs, N. J., 1958.

14. "Waste Treatment and Disposal Progress Report for October and November 1961, ORNL-TM-133, Sect. 9.0.

15. "Waste Treatment and Disposal Progress Report for June and July 1961, ORNL-TM-15. 


\section{INTERNATIONAL DISTRIBUTION}

1. ORNL - Y-12 Technical Iibrary Document Reference Section

2-4. Central Research Library

5-14. Iaboratory Records Department

15. Laboratory Records, ORNL R.C.

16-17. R. E. Blanco

18. J. 0. Blomeke

19. W. J. Boegly, Jr.

20. R. L. Bradshaw

21. J. C. Bresee

22. F. N. Browder

23. K.B. Brown

24. P. H. Carrigan

25. W. E. Clark

26. K. E. Cowser

27. F. L. Culler

28. W. de Laguna

29. F. M. Empson

30. D. E. Ferguson

31. H. W. Godbee

32. H. E. Goeller

33. J. M. Googin
34. C. W. Hancher

35. C. E. Haynes

36. R. F. Hibbs

37. R. R. Holcomb

38. J. M. Holmes

39. D. G. Jacobs

40. W. H. Jordan

41. H. Kubota

42. T. F. Lomenick

43. K. Z. Morgan

44. R. J. Morton

45. E. L. Nicholson

46. F. I. Parker

47. J. J. Perona

48. R. M. Richardson

49. J. T. Roberts, IAEA, Vienna

50-5I. E. G. Struxness

52. J. C. Suddath

53. J.A. Swartout

54. T. Tamura.

55. J.W. UIImann

56. M. E. Whatley

\section{EXTERNAL DISTRIBUTION}

57. E. I. Anderson, AEC, Washington

58. W. G. Belter, AEC, Washington

59. W. H. Regan, AEC, Washington

60. J.A. Buckham, Phillips Petroleum Company

61. H. J. Carey, Jr., Carey Salt Company, Hutchinson, Kansas

62. C. W. Christenson, Los Alamos Scientific Laboratory

63. F. F. Gloyna, University of Texas, Austin

64. I. P. Hatch, Brookhaven National Laboratory

65. W. B. Heroy, Sr., Geotechnical Corp., Dallas, Texas

66. H. H. Hess, Chairman, Earth Science Division, Commission on Ground Disposal of Radioactive Waste, Princeton University, Princeton, N.J.

67. O. F. Hill, Hanford

68. J.R. Horan, AEC Idaho

69. J. H. Horton, Stanford Research Institute

70. E. R. Irish, Hanford

71. A. A. Jonke, Argonne National Laboratory

72. K. K. Kennedy, AEC, Idaho

73. W. J. Kaufman, University of California, Berkeley

74. S. Lawroski, Argonne National Laboratory 
75. J.A. Lieberman, AEC, Washington

76. J.A. McBride, Phillips Petroleum Company

77. R. L. Moore, Hanford

78. J.W. Morris, du Pont, Savannah River

79. R. L. Nace, Water Resources Division, USGS, Washington, NAS-NRC

80. C. M. Patterson, du Pont, Savannah River

81. A. M. Platt, Hanford

82. W. H. Reas, Hanford

83. C. S. Shoup, AEC, ORO

84. I. Silverman, Harvard Graduate School of Public Health

85. J. I. Stevens, Phillips Petroleum Company

86. C. M. Slansky, Phillips Petroleum Company

87. W. H. Swift, Hanford

88. V. R. Thayer, du Pont, Wilmington

89. Abel Wolman, Chairman, National Academy of Sciences, Committee on Waste Disposal, Johns Hopkins

90. H. M. Roth, ORO

91. J. C. Frye, State Geological Survey Div。, Urbana, III. 92-106. DIIE 


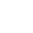


